\title{
Supporting Information \\ Electrocatalytic Nitrate Reduction on Oxide-Derived Silver with Tunable Selectivity to Nitrite and Ammonia
}

Hengzhou Liu, ${ }^{a}$ Jaeryul Park, ${ }^{a}$ Yifu Chen, ${ }^{\text {a }}$ Yang Qiu, ${ }^{b}$ Yan Cheng, ${ }^{a}$ Kartik Srivastava, ${ }^{a}$ Shuang Gu, ${ }^{\mathrm{c}}$ Brent H. Shanks, ${ }^{a}$ Luke T. Roling, ${ }^{* a}$ Wenzhen $\mathrm{Li}^{* a, d}$

${ }^{a}$ Department of Chemical and Biological Engineering, Iowa State University, 618 Bissell Road, Ames, IA 50011 (USA).

${ }^{b}$ Institute for Integrated Catalysis, Energy and Environment Directorate, Pacific Northwest National Laboratory, 902 Battelle Blvd., Richland, WA 99352 (USA).

${ }^{c}$ Department of Mechanical Engineering, Wichita State University, 1845 Fairmount St, Wichita, KS 67260 (USA).

${ }^{\mathrm{d}}$ US Department of Energy Ames Laboratory, 2408 Pammel Drive, Ames, IA 50011 (USA).

*To whom correspondence should be addressed:

Wenzhen Li: wzli@iastate.edu, Luke T. Roling: roling@iastate.edu 


\section{Table of Contents}

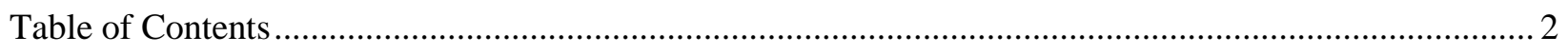

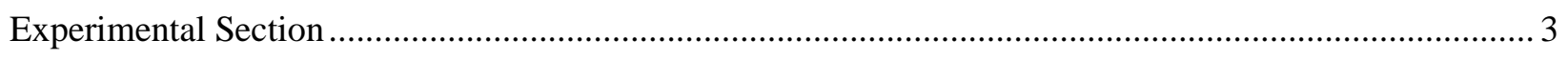

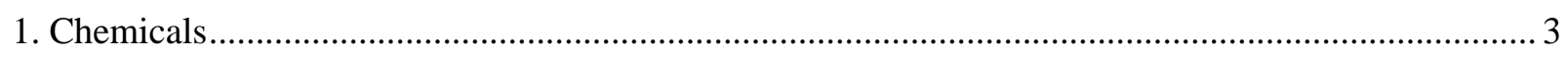

2. Preparation of working electrodes ..................................................................................... 3

3. Electrocatalytic and catalytic activity measurements ................................................................. 4

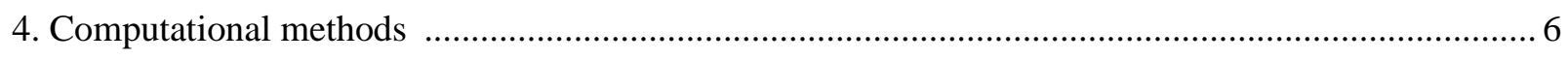

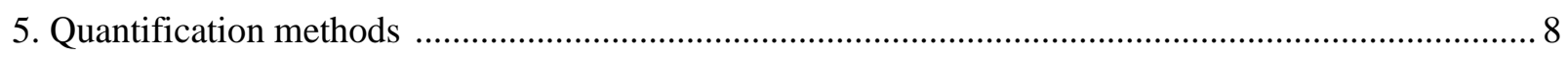

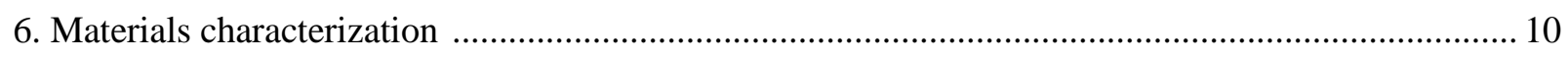

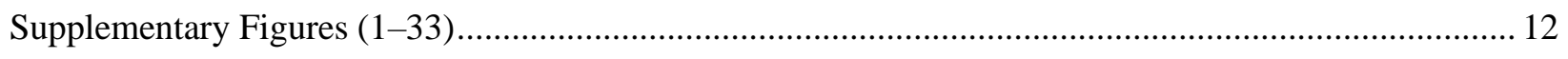

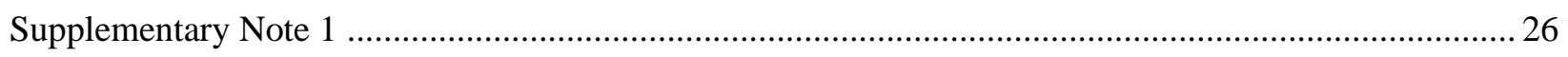

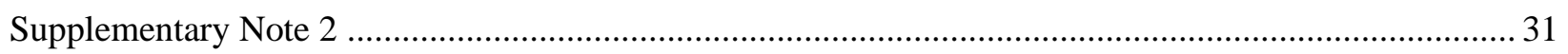

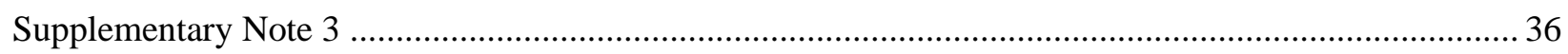

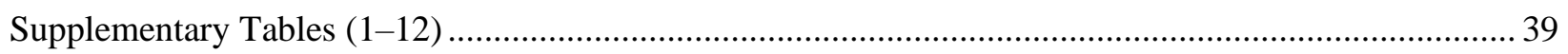

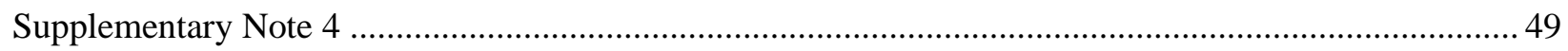

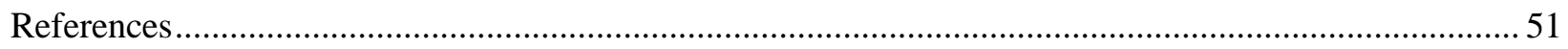

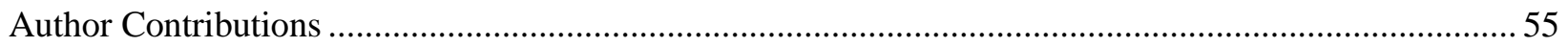




\section{Experimental Section}

\section{Chemicals}

All chemicals were used as received without purification. Silver foil $(0.5 \mathrm{~mm}$ thick, $99.9985 \%)$, copper foil $(0.5 \mathrm{~mm}$ thick, $99.9985 \%)$, platinum foil $(0.025 \mathrm{~mm}$ thick, $99 \%)$, tin foil (0.025 mm thick, $99.9 \%)$, titanium foil (0.89 mm thick, 99.7\%), zinc foil (0.1 mm thick, $99.994 \%)$, iron foil $(0.5 \mathrm{~mm}$ thick, $99.99 \%)$, nickel foil $(0.1 \mathrm{~mm}$ thick, $99.5 \%)$, palladium foil $(0.025 \mathrm{~mm}$ thick, $99.9 \%)$, gold foil (0.05 mm thick, $99.95 \%)$, lead foil (0.76 mm thick, $99.8 \%)$, molybdenum foil $(0.1 \mathrm{~mm}$ thick, $99.95 \%)$, tungsten foil $(0.25 \mathrm{~mm}$ thick, $99.95 \%)$, aluminum foil $(0.1 \mathrm{~mm}$ thick, $99.99 \%)$, cobalt foil ( $0.1 \mathrm{~mm}$ thick, $99.95 \%)$, zirconium foil $(0.2 \mathrm{~mm}$ thick, $99.8 \%)$, vanadium foil (1.0 mm thick, 99.5\%), and hydroxylamine hydrochloride $\left(\mathrm{NH}_{2} \mathrm{OH} \cdot \mathrm{HCl}, 99 \%\right)$ were purchased from Alfa Aesar. Bismuth plate $(>99.99 \%)$ was purchased from Amazon. Potassium nitrate $\left(\mathrm{KNO}_{3}, 99.7 \%\right)$, potassium chloride $(\mathrm{KCl}, 100 \%)$, potassium phosphate dibasic $\left(\mathrm{K}_{2} \mathrm{HPO}_{4}, \geq 98 \%\right)$, potassium phosphate monobasic $\left(\mathrm{KH}_{2} \mathrm{PO}_{4}, \geq 99 \%\right)$, sodium carbonate $\left(\mathrm{Na}_{2} \mathrm{CO}_{3}, 100 \%\right)$, sodium chloride $(\mathrm{NaCl}, \geq 99 \%)$, sodium sulfate $\left(\mathrm{Na}_{2} \mathrm{SO}_{4}, \geq 99 \%\right)$, sodium bicarbonate $\left(\mathrm{NaHCO}_{3}, 100 \%\right)$, hydrogen peroxide $\left(\mathrm{H}_{2} \mathrm{O}_{2}, 30 \%\right)$, nitric acid $\left(\mathrm{HNO}_{3}, 70 \%\right)$, hydrochloric acid $(\mathrm{HCl}, 37 \%)$, phosphoric acid $\left(\mathrm{H}_{3} \mathrm{PO}_{4}, \geq 85 \%\right)$, and methanol (HPLC grade) were purchased from Fisher Chemical. Sodium salicylate $(\geq 99.5 \%)$, sodium hydroxide $(\mathrm{NaOH}, \geq 97 \%)$, potassium hydroxide $(\mathrm{KOH}, \geq 85 \%)$, sodium nitroferricyanide dihydrate $\left(\mathrm{Na}_{2}\left[\mathrm{Fe}(\mathrm{CN})_{5} \mathrm{NO}\right] \cdot 2 \mathrm{H}_{2} \mathrm{O}, \geq 99 \%\right)$, sodium hypochlorite solution ( $\mathrm{NaOCl}$, available chlorine 4.00-4.99\%), $\mathrm{N}$-(1-Naphthyl)ethylenediamine dihydrochloride (NED, $\geq 97 \%$ ), sulfanilamide ( $\geq 99 \%)$, and palladium on active carbon ( $\mathrm{Pd} / \mathrm{C}, 5$ wt.\% Pd loading) were purchased from Sigma-Aldrich. Silver nanopowder (80-100 nm, 99.99\%) was purchased from US Research Nanomaterials, Inc. Potassium nitrite $\left(\mathrm{KNO}_{2}, 97 \%\right)$, lead(II) nitrate $\left(\mathrm{Pb}\left(\mathrm{NO}_{3}\right)_{2}, \geq 99 \%\right)$, and $n$-Octylamine (>99\%) were purchased from Acros Organic. 8quinolinol was purchased from TCI. Ammonia standard solution (100 mg L L as $\left.\mathrm{NH}_{3}-\mathrm{N}\right)$ was purchased from Hach. Silver standard solution $\left(1,000 \mu \mathrm{g} \mathrm{mL} \mathrm{m}^{-1}\right.$ of $\mathrm{Ag}^{+}$in $5 \% \mathrm{v} / \mathrm{v}$ nitric acid) was purchased from Inorganic Ventures. Plain carbon cloth, Vulcan XC-72R, PTFE gaskets, and Nafion 115 membrane were purchased from Fuel Cell Store. 40\% Pt on Vulcan XC-72 (Pt/C) and $\mathrm{IrO}_{2}$ powder were purchased from Premetek. Argon (Ar, Ultra High Purity, 99.999\%), hydrogen $\left(\mathrm{H}_{2}\right.$, Ultra High Purity, $\left.99.999 \%\right)$, and carbon dioxide $\left(\mathrm{CO}_{2}\right.$, industrial grade) were purchased from Airgas. $\mathrm{H}_{2}$ calibration gases (10 ppm, 100 ppm, 1,000 ppm, 5,000 ppm, 10,000 ppm, balance helium) and $\mathrm{N}_{2} \mathrm{O}$ calibration gases (95 ppm, 1,000 ppm, balance nitrogen) were purchased from Cal Gas Direct. Nitrogen $\left(\mathrm{N}_{2}\right)$ calibration gases $(100$ ppm, 1,000 ppm, 10,000 ppm, 100,000 ppm, balance helium) were purchased from Shop Cross. Nitrogen oxides detector tube (No. 175U, 1-60 ppm) was purchased from Kitagawa America. Deionized (DI) water (18.2 M $\Omega$ cm, Barnstead ${ }^{\mathrm{TM}}$ E-Pure $^{\mathrm{TM}}$ ) was used for all experiments in this work.

\section{Preparation of working electrodes}

Oxide-derived silver (OD-Ag) was prepared in a standard three-electrode system by a modified square wave voltammetric (SWV) method according to Ma et al. ${ }^{16}$ A polycrystalline silver foil (0.5 mm thick, 99.9985\%, Alfa Aesar), a silver/silver chloride (Ag/AgCl) electrode (saturated $\mathrm{KCl}, E^{0}=0.197 \mathrm{~V} v s$. SHE, Pine Research), and a platinum foil were used as the working electrode, reference electrode, and counter electrode, respectively. 0.2 $\mathrm{M} \mathrm{NaOH}$ was used as the electrolyte. To synthesize OD- $\mathrm{AgO}_{x}$, symmetric square-wave pulse potential from 0 to $1 \mathrm{~V}_{\mathrm{Ag} / \mathrm{AgCl}}$ 
was applied by a Biologic SP-300 potentiostat/galvanostat on the Ag foil at a frequency of $500 \mathrm{~Hz}$ for $3 \mathrm{~h}$ (Supplementary movie 1 , with a $16 \mathrm{X}$ play rare). Then, a constant potential $(-1.30 \mathrm{~V} \mathrm{Ag} / \mathrm{AgCl})$ was applied for $10 \mathrm{~min}$ to reduce $\mathrm{OD}-\mathrm{AgO}_{x}$ to $\mathrm{OD}-\mathrm{Ag}$.

The electrode with Ag nanoparticles (80-100 nm, 99.99\%, US Research Nanomaterials) on $\mathrm{Ag}$ foil (Ag NPs/Ag) was prepared by airbrushing a 2-propanol dispersion of Ag NPs (10 mg $\mathrm{mL}^{-1}$ ) and Nafion on both sides of the Ag foil. The mass ratio of Ag NPs and Nafion was 4:1. The catalyst loading was controlled at $1.5 \mathrm{mg}_{\mathrm{Ag}} \mathrm{cm}^{-2}$.

\section{Electrocatalytic and catalytic activity measurements}

\subsection{Electrochemical measurements Electrochemical measurements.}

Linear sweep voltammetry (LSV) measurements were carried out in a single-compartment cell with a three-electrode configuration without stirring. The electrolyte consisted of $0.1 \mathrm{M} \mathrm{KCl}$, and its $\mathrm{pH}$ was adjusted to 4 by adding hydrochloric acid. The scan rate was $5 \mathrm{mV} \mathrm{s}^{-1}$.

The electrochemical reduction of $\mathrm{NO}_{3}{ }^{-}$(NO3RR) was performed by chronoamperometry (CA) at room temperature in a dual-chamber $\mathrm{H}$-type cell with a three-electrode configuration, and the cathode chamber was airtight. Each chamber contained $15 \mathrm{~mL}$ of the electrolyte $(0.1 \mathrm{M} \mathrm{KCl}$, $\mathrm{pH}=4$ ) and the two chambers were separated by a Nafion 115 membrane $\left(\mathrm{K}^{+}\right.$form). $\mathrm{KNO}_{3}$ was added to the catholyte, which was magnetically stirred at 350 r.p.m. by a PTFE-coated stir bar (20 $\times 6 \mathrm{~mm}$ ). The geometric area of the working electrode was chosen depending on the experimental conditions, typically 2, 4, or $6 \mathrm{~cm}^{2}$. Specifically, at low overpotentials and $\mathrm{NO}_{3}{ }^{-}$concentration such as -1.00 and $-1.10 \mathrm{~V}_{\mathrm{Ag} / \mathrm{AgCl}}$ with $0.01 \mathrm{M} \mathrm{NO}_{3}{ }^{-}$, a $6 \mathrm{~cm}^{2}$-electrode was used to ensure the reaction was complete in a few hours. At high overpotentials or $\mathrm{NO}_{3}{ }^{-}$concentration, smaller electrodes were used to avoid overload of the potentiostat. A graphite rod was used as the counter electrode. All electrode potentials were measured against the $\mathrm{Ag} / \mathrm{AgCl}$ reference electrode

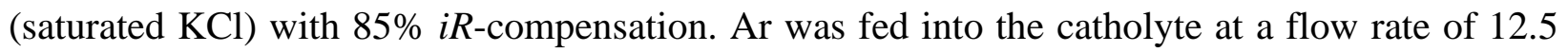
$\mathrm{mL} \mathrm{min}^{-1}$. The outlet gas from the cathode chamber was bubbled into an external trapping solution containing $25 \mathrm{~mL}$ of $0.1 \mathrm{M} \mathrm{KCl}(\mathrm{pH}=3)$ to absorb any $\mathrm{NH}_{3}$ that evolved from the system. The gas flow was then introduced to the on-line gas chromatography (GC) to quantify $\mathrm{H}_{2}$. The duration of CA was chosen depending on the total applied charge, as detailed in the Figures captions. The current density was calculated based on the geometric area (for both sides) of the electrode. The entire experimental setup is shown in Figure S8.

The conversion of $\mathrm{NO}_{3}{ }^{-}(X)$ and selectivity to product $i\left(S_{i}, i=\mathrm{NH}_{4}{ }^{+}, \mathrm{NO}_{2}{ }^{-}\right.$, or $\left.\mathrm{NH}_{2} \mathrm{OH}\right)$ were calculated by

$$
\begin{aligned}
& X=\frac{n_{0}-n}{n_{0}} \times 100 \% \\
& S_{i}=\frac{n_{i}}{n_{0}-n} \times 100 \%
\end{aligned}
$$


where $n_{0}$ is the initial amount of $\mathrm{NO}_{3}{ }^{-}(\mathrm{mol}) ; n$ is the amount of $\mathrm{NO}_{3}{ }^{-}$after electrolysis $(\mathrm{mol}) ; n_{i}$ is the amount of product $i(\mathrm{~mol})$.

The faradaic efficiency of product $i\left(\mathrm{FE}_{i}\right)$ was calculated by

$$
\mathrm{FE}_{i}=\frac{n_{i} z_{i} F}{Q} \times 100 \%
$$

where $z_{i}$ is the number of electrons transferred to product $i ; F$ is the Faraday constant $\left(96,485 \mathrm{C} \mathrm{mol}^{-1}\right) ; Q$ is the total charge (C) passed through the electrolytic cell.

\subsection{Catalytic reduction of $\mathrm{NO}_{2}^{-}$}

Catalytic reduction of $\mathrm{NO}_{2}^{-}$was carried out at room temperature in a gastight reactor. Specifically, $50 \mathrm{mg}$ of $\mathrm{Pd} / \mathrm{C}$ was suspended in $15 \mathrm{~mL}$ of the $\mathrm{NO}_{2}{ }^{-}$-containing solution which was magnetically stirred at 800 r.p.m. The solution was sparged with $\mathrm{CO}_{2}$ at $25 \mathrm{~mL} \mathrm{~min}{ }^{-1}$ by a gas dispersion tube (Ace Glass, $7 \mathrm{~mm}$ O.D., 25-50 micron porosity) during the test to maintain the $\mathrm{CO}_{2}$-buffered condition. ${ }^{1}$ After the solution was saturated with $\mathrm{CO}_{2}(\mathrm{pH} \sim 7), \mathrm{H}_{2}$ was fed at $25 \mathrm{~mL}$ $\min ^{-1}$ via another gas dispersion tube. During the measurement, the solution was sampled periodically from the reactor, followed by dilution and filtration for product analysis.

The observed reaction rate constant $k_{\mathrm{obs}}\left(\mathrm{min}^{-1}\right)$ was calculated assuming pseudo-first-order dependence on $\mathrm{NO}_{2}{ }^{-}$concentration $\left(\mathrm{H}_{2}\right.$ is in excess) by

$$
\frac{\mathrm{d} c}{\mathrm{~d} t}=-k_{\mathrm{obs}} c
$$

where $c$ is the concentration of $\mathrm{NO}_{2}^{-}\left(\mathrm{mg} \mathrm{L}^{-1}\right)$ and $t$ is the reaction time (min). The rate constant was normalized to the concentration of surface $\mathrm{Pd}$ in the solution $\mathrm{by}^{2}$

$$
k=\frac{k_{\mathrm{obs}}}{\frac{A m M}{a N_{\mathrm{A}} V}}
$$

where $A$ is the active surface area of $\mathrm{Pd}\left(\mathrm{m}^{2} \mathrm{~g}^{-1}\right), m$ is the mass of $\mathrm{Pd}$ in the reactor $(0.050$ $\mathrm{g}), M$ is the molar mass of $\mathrm{Pd}\left(106.42 \mathrm{~g}_{\mathrm{Pd}} \mathrm{mol}^{-1}\right), a$ is the cross-sectional area of one Pd atom (7.87 $\left.\times 10^{-20} \mathrm{~m}^{2}\right), N_{\mathrm{A}}$ is the Avogadro constant $\left(6.02 \times 10^{23} \mathrm{~mol}^{-1}\right), V$ is the volume of the $\mathrm{NO}_{2}^{-}$containing solution $(0.015 \mathrm{~L})$. The unit of the normalized $k$ calculated from the above equation is $\mathrm{L} \mathrm{g}_{\mathrm{Pd}}{ }^{-1} \min ^{-1}$.

\subsection{Combined process for agricultural wastewater denitrification}

The combined denitrification process was carried out in three media: 1) $0.1 \mathrm{M} \mathrm{KCl}$;2) simulated waste stream from ion-exchange columns (containing $400 \mathrm{mg} \mathrm{L}^{-1}$ of $\mathrm{NaCl}, 400 \mathrm{mg} \mathrm{L}^{-1}$ of $\mathrm{Na}_{2} \mathrm{SO}_{4}$, and $8,000 \mathrm{mg} \mathrm{L}{ }^{-1}$ of $\mathrm{NaHCO}_{3}$ in DI water); ${ }^{3}$ and 3) real agricultural wastewater obtained from Des Moines Water Works, Iowa (filtered to remove the insoluble matters). Additional $\mathrm{KNO}_{3}$ was added to set the concentration of $\mathrm{NO}_{3}{ }^{-}$at $0.01 \mathrm{M}$ (corresponding to 140 
ppm-N) to simulate the $\mathrm{NO}_{3}{ }^{-}$content enriched in waste streams. The two-step denitrification treatment was performed as described in electrochemical measurements (for $\mathrm{NO}_{3}{ }^{-}$to $\mathrm{NO}_{2}{ }^{-}$) and catalytic measurements (for $\mathrm{NO}_{2}{ }^{-}$to $\mathrm{N}_{2}$ ).

We also utilized a proton-exchange membrane (PEM)-based water electrolyzer to generate on-site $\mathrm{H}_{2}$ for the second step (catalytic reduction of $\mathrm{NO}_{2}{ }^{-}$) (Figure S29). The membrane electrode assembly (MEA) consisted of a $\mathrm{Pt} / \mathrm{C}$ cathode, $\mathrm{IrO}_{2}$ anode, and a Nafion 115 membrane $\left(\mathrm{H}^{+}\right.$form). The electrodes were prepared by spraying the dispersion containing the catalyst and Nafion ionomer (4:1 in mass) onto plain carbon cloths. The catalyst loading was $1.15 \mathrm{mg} \mathrm{cm}^{-2}$ (in Pt) for the cathode and $3.75 \mathrm{mg} \mathrm{cm}^{-2}$ (in $\mathrm{IrO}_{2}$, Premetek) for the anode. The MEA was hot-pressed at $130^{\circ} \mathrm{C}$ and 1,000 psi for 3 min before assembled into the cell hardware containing two PTFE gaskets (Fuel Cell Store) and two graphite end plates with serpentine flow channels. The active area of the electrodes was $5 \mathrm{~cm}^{2}$. The cell was operated at $80{ }^{\circ} \mathrm{C}$ with DI water supplied in both cathode and anode chambers at a flow rate of $5.5 \mathrm{~mL} \mathrm{~min}^{-1}$ by a peristaltic pump. Repeated CV scans were carried out between 0 and $1.6 \mathrm{~V}$ until a stable $\mathrm{CV}$ curve was obtained. Constant-current electrolysis was then performed at $1.4 \mathrm{~A}$, and the generated $\mathrm{H}_{2}$ from the cathode compartment was directly sparged in the $\mathrm{NO}_{2}{ }^{-}$-containing solution.

\section{Computational methods}

The Vienna $a b$ initio Simulation Package (VASP) was used for density functional theory (DFT) calculations. ${ }^{4-5}$ Projector augmented-wave (PAW) potentials were implemented to describe electron-ion interactions, ${ }^{6-7}$ and the Perdew-Wang functional was used within the generalized gradient approximation (GGA-PW91) to determine exchange-correlation energies. ${ }^{8}$ Electronic energies were calculated to a precision of $10^{-4} \mathrm{eV}$, using a kinetic energy cutoff of $400 \mathrm{eV}$. Geometry optimizations were performed until the forces on all atoms were less than $0.02 \mathrm{eV} \AA^{-1}$. Optimized lattice constants were calculated as follows (experimental values in parentheses, all values in $\AA$ ): $\mathrm{Ag} 4.16$ (4.09), Cu 3.64 (3.61), and Pd 3.96 (3.89). ${ }^{9}$

$\mathrm{Ag}, \mathrm{Pd}$, and $\mathrm{Cu}$ foil electrodes were represented by fcc(111) facets in calculations. The wave-like structure of OD-Ag was represented by the (211) facet of Ag. This was chosen as a first approximation to a surface exposing a higher fraction of undercoordinated metal atoms in comparison to the foil. The (111) surfaces were constructed with $3 \times 3$ surface unit cells and four metal layers; (211) surfaces were constructed in $1 \times 3$ unit cells with 12 metal layers. The bottom two layers of (111) cells and bottom six layers of (211) cells were fixed at the bulk-optimized lattice positions and the remaining layers and adsorbate atoms were allowed to fully relax during

optimization. The distance between periodic metal slabs was at least $13 \AA$ to minimize interactions between adjacent slabs. The surface Brillouin zone of all prepared surfaces was sampled with a 6 $\times 6 \times 1 k$-point mesh. ${ }^{10}$

All gas-phase Gibbs free energies $\left(G_{x}\right)$ were calculated in the following manner:

$$
G_{x}=E_{x}+Z P E_{x}-T S_{x}
$$


where $E_{x}$ is the total energy of the adsorbate, $Z P E_{x}$ is the calculated zero-point energy correction of $x, T$ is the absolute temperature $(298 \mathrm{~K})$, and $S_{x}$ is the calculated entropy of $x$. ZPE and $S$ were estimated from vibrational frequency calculations of adsorbed species, including translational, vibrational, and rotational modes. Estimates were obtained using a second-order finite difference numerical differentiation of forces and a step size of $0.015 \AA$, assuming a harmonic oscillator. The ZPE and $S$ of species on $\mathrm{Pd}(111)$ were used for $\mathrm{Cu}(111)$ and $\mathrm{Ag}(111)$. Due to the small differences in energetics relevant to the major conclusions of this study, we calculated $Z P E$ and $S$ for all intermediates on $\mathrm{Cu}(111)$ along the reaction pathway between $\mathrm{NO}_{3}$ * and $\mathrm{NO}^{*}$. The $\mathrm{Pd}(111)$ values were used for intermediates after $\mathrm{Cu}(111)$, as the conclusions of this study were not sensitive to fine differences in those values. $Z P E$ and $S$ were calculated separately for $\operatorname{Ag}(211)$ due to the different surface geometry. Free energies of all adsorbed states were calculated relative to the free energies of $\mathrm{NO}_{3}{ }^{-}(\mathrm{l}), \mathrm{H}_{2} \mathrm{O}(\mathrm{g})$ and $\mathrm{H}_{2}(\mathrm{~g})$, and the total energy of the clean slab. For example, for adsorbed $\mathrm{NOH}^{*}$,

$$
G_{\mathrm{NOH}^{*}}=\left(E_{\mathrm{NOH}^{*}}+Z P E_{\mathrm{NOH}^{*}}-T S_{\mathrm{NOH}^{*}}\right)-E_{\mathrm{slab}}-G_{\mathrm{NO}_{3}-(\mathrm{l})}+2 G_{\mathrm{H}_{2} \mathrm{O}(\mathrm{g})}-\frac{5}{2} G_{\mathrm{H}_{2}(\mathrm{~g})}
$$

where $E_{\mathrm{NOH}^{*}}$ is the total energy of the adsorbed $\mathrm{NOH}^{*}$ on the slab, and $E_{\text {slab }}$ is the total energy of the clean slab. The free energy of the nitrate ion in the aqueous phase $\left(\mathrm{NO}_{3}{ }^{-}(1)\right)$ was calculated based on a relevant previous study and was used as a reference state in reaction energetics. ${ }^{11}$ Given that difference of adsorption energies of $\mathrm{NO}_{3}$ with respect to $\mathrm{HNO}_{3}(\mathrm{~g})$ and $\mathrm{H}_{2}(\mathrm{~g})$ between PW91 used in our study and PBE used in the previous study was less than $0.1 \mathrm{eV}$, we applied the same extent of correction $(+1.12 \mathrm{eV})$ to $\mathrm{HNO}_{3}(\mathrm{~g})$ in this study. Activation energies were calculated using the CI-NEB method with a force cutoff of $0.02 \mathrm{eV} \AA^{-1} .{ }^{12}$ All transition states were verified by confirming the presence of a single imaginary vibrational mode.

The effects of applied electrochemical potential were computed using the computational hydrogen electrode developed by Nørskov and coworkers. ${ }^{13}$ The reversible hydrogen electrode (RHE) was set as the electrochemical reference, with hydrogen gas in equilibrium with protons and electrons at a defined potential of $0.00_{\mathrm{RHE}}$. The free energy change of electrochemical steps was therefore calculated as $\Delta G=\Delta E+\triangle Z P E-T \Delta S+|e| U$, where $e$ is the absolute charge of an electron, and $U$ is the operating potential versus the RHE. Therefore, a more negative operating potential enhances the proton-electron transfer of electrochemical reduction steps. We note that only the free energies of electrochemical steps [i.e., those involving the transfer of a protonelectron $\left(\mathrm{H}^{+}-\mathrm{e}^{-}\right)$pair] are corrected for potential effects; the energetics of $\mathrm{N}-\mathrm{O}$ bond breaking effects occurring without concerted proton-electron $\left(\mathrm{H}^{+}-\mathrm{e}^{-}\right)$transfer are unaffected. The values reported in reference to the $\mathrm{Ag} / \mathrm{AgCl}$ electrode were calculated by shifting the potential vs. RHE (the typical reference for the computational hydrogen electrode) according to the difference in standard reduction potentials. Potentials $(E)$ versus $\mathrm{Ag} / \mathrm{AgCl}$ in saturated $\mathrm{KCl}$ relative to those calculated $v s$. RHE were therefore calculated by:

$$
E_{\mathrm{Ag} / \mathrm{AgCl}}=E_{\mathrm{RHE}}-0.197 \mathrm{~V}-0.059 \mathrm{~V} \times \mathrm{pH}
$$




\section{Quantification methods}

\subsection{Quantification of $\mathrm{NO}_{3}{ }^{-}$and $\mathrm{NO}_{2}{ }^{-}$}

$\mathrm{NO}_{3}^{-}$and $\mathrm{NO}_{2}{ }^{-}$were analyzed by High-Performance Liquid Chromatography (HPLC) $^{14-15}$ (Agilent Technologies, 1260 Infinity II LC System) equipped with a variable wavelength detector (Agilent 1260 Infinity Variable Wavelength Detector VL). The wavelength of $213 \mathrm{~nm}$ was used for detection. A C18 HPLC column (Gemini ${ }^{\circledR} 3 \mu \mathrm{m}, 110 \AA$ A, $100 \times 3 \mathrm{~mm}$ ) was used for analysis at $25{ }^{\circ} \mathrm{C}$ with a binary gradient pumping method to drive mobile phase at $0.4 \mathrm{~mL}$ $\min ^{-1}$. The mobile phase consisted of $0.01 \mathrm{M} n$-Octylamine in a mixed solution containing $30 \mathrm{vol} \%$ of methanol and $70 \mathrm{vol} \%$ of DI water, and the $\mathrm{pH}$ of the mobile phase was adjusted to 7.0 with $\mathrm{H}_{3} \mathrm{PO}_{4}$. The running time was 30 min for each sample, and the retention time for $\mathrm{NO}_{3}{ }^{-}$and $\mathrm{NO}_{2}{ }^{-}$ was around 18 and $16 \mathrm{~min}$, respectively. The calibration solutions for $\mathrm{NO}_{3}{ }^{-}$or $\mathrm{NO}_{2}{ }^{-}$were prepared with $\mathrm{KNO}_{3}$ and $\mathrm{KNO}_{2}$ in the concentration range of $0.0625-2 \mathrm{mM}$ (Figure S6).

$\mathrm{NO}_{2}{ }^{-}$at lower concentrations was determined by colorimetry based on the Griess reaction. Two reagents were prepared and stored at $4{ }^{\circ} \mathrm{C}$, including a) solution $\mathrm{A}$, containing 10 $\mathrm{mg} \mathrm{mL} L^{-1}$ of sulfanilamide and $1.2 \mathrm{M} \mathrm{HCl}$; and b) solution $\mathrm{B}$, containing $1.0 \mathrm{mg} \mathrm{mL}^{-1}$ of $N$-(1Naphthyl)ethylenediamine dihydrochloride (NED). Specifically, the coloring reagent was prepared by mixing equal volumes of solutions $\mathrm{A}$ and B. $0.6 \mathrm{~mL}$ of the coloring reagent was then mixed with $4 \mathrm{~mL}$ of the neutralized sample solution at room temperature. The absorbance measurement was performed on a UV-Vis spectrophotometer (Shimadzu UV-2700) at a wavelength of $540 \mathrm{~nm}$ after 15 min of color development. The calibration curve (Figure S5) was established by testing a series of standard $\mathrm{NO}_{2}{ }^{-}$solutions in the concentration range of 2.7-65.2 $\mu \mathrm{M}$.

\subsection{Quantification of $\mathrm{H}_{2}$ and $\mathrm{N}_{2}$}

The produced $\mathbf{H}_{2}$ and $\mathbf{N}_{2}$ from the electrochemical reactor were analyzed by an on-line GC (SRI Instruments, 8610C, Multiple Gas \#3) equipped with HayeSep D and MolSieve $5 \AA$ columns. A thermal conductivity detector was used to detect $\mathrm{H}_{2}$ and $\mathrm{N}_{2}$. The calibration curves for $\mathrm{H}_{2}$ (10-10,000 ppm, Cal Gas Direct) and $\mathrm{N}_{2}(100-100,000 \mathrm{ppm}$, Shop Cross) were established by analyzing the calibration gases.

To quantify the generated $\mathrm{H}_{2}$ during the NO3RR measurements, the GC program was started at 2 min after NO3RR was initiated. A 12.5-min programmed cycle was repeated, including $8 \mathrm{~min}$ of the GC running period and $4.5 \mathrm{~min}$ of the cooling period. For each cycle, the rate of $\mathrm{H}_{2}$ generation $\left(r, \mathrm{~mol} \mathrm{~s}^{-1}\right)$ was calculated by

$$
r=c \times 10^{-6} \times \frac{p \dot{V} \times 10^{-6} \div 60}{R T}
$$

where $c$ is the $\mathrm{H}_{2}$ content (ppm); $\dot{V}$ is the volumetric flow rate of the inlet gas $(12.5 \mathrm{~mL}$ $\left.\min ^{-1}\right) ; p$ is the atmospheric pressure $\left(p=1.013 \times 10^{5} \mathrm{~Pa}\right) ; R$ is the gas constant $\left(R=8.314 \mathrm{~J} \mathrm{~mol}^{-1}\right.$ $\left.\mathrm{K}^{-1}\right) ; T$ is the room temperature $(293.15 \mathrm{~K})$. The total amount of $\mathrm{H}_{2}$ production (mol) was 
calculated by integrating the plot of $\mathrm{H}_{2}$ production rate $\left(\mathrm{mol} \mathrm{s} \mathrm{s}^{-1}\right.$ ) vs. reaction time (s) with polynomial curve fitting.

We also examined $\mathbf{N}_{2}$ from catalytic $\mathrm{NO}_{2}{ }^{-}$reduction using on-line $\mathbf{G C}$. The experiment was carried out as described in catalytic measurements with a lower feeding rate of $\mathrm{H}_{2}(14.5 \mathrm{~mL}$ $\left.\min ^{-1}\right)$ and $\mathrm{CO}_{2}\left(2.5 \mathrm{ml} \mathrm{min}{ }^{-1}\right)$, and a higher $\mathrm{NO}_{2}{ }^{-}$concentration $(0.5 \mathrm{M})$ to ensure the signal of $\mathrm{N}_{2}$ was detectable by GC. The total reaction time was $2 \mathrm{~h}$. To quantify the generated $\mathrm{N}_{2}$, the GC program was started at 5 min after the catalytic reduction was initiated. An 8-min programmed cycle was repeated, including 6 min of the GC running period and $2 \mathrm{~min}$ of the cooling period. 15 $\mathrm{GC}$ runs were performed in total during the reaction. We considered the consumption of feeding gases $\left(\mathrm{H}_{2}\right.$ and $\left.\mathrm{CO}_{2}\right)$ and generation of $\mathrm{N}_{2}$ during the reduction of $\mathrm{NO}_{2}^{-}\left(2 \mathrm{NO}_{2}^{-}+3 \mathrm{H}_{2}+2 \mathrm{CO}_{2} \rightarrow\right.$ $\mathrm{N}_{2}+2 \mathrm{HCO}_{3}^{-}+2 \mathrm{H}_{2} \mathrm{O}$ ), which results in a non-negligible decrease in the flow rate of the gas mixture. The net consumption rate of gas $\left(\mathrm{mL} \mathrm{min}^{-1}\right)$ was calculated by

$$
\text { Net consumption rate }=\frac{3+2-1}{2} \times\left(n_{0}-n\right) \times \frac{R T}{p} \times 10^{6} \div \frac{t}{60}
$$

where $n_{0}$ is the initial amount of $\mathrm{NO}_{2}^{-}$(mol); $n$ is the amount of $\mathrm{NO}_{2}{ }^{-}$after the reaction (mol); $t$ is the reaction time (s). The calibrated flow rate of the GC inlet gas $\left(\dot{V}^{\prime}\right)$ was then obtained by subtracting the net consumption rate from the total feeding rate of $\mathrm{H}_{2}$ and $\mathrm{CO}_{2}$ into the reactor. Other steps for calculating the $\mathrm{N}_{2}$ production were the same as for $\mathrm{H}_{2}$.

\subsection{Quantification of $\mathrm{NO}_{2}$ and NO}

The total concentration of $\mathbf{N O}_{2}$ and $\mathbf{N O}$ in the outlet gas of the reactor was tested by nitrogen oxides detector tubes (Kitagawa America, No. 175U) with a measuring range of 1-60 ppm. Gas was sampled by an aspirating pump (Kitagawa America, AP-20), and the content of total $\mathrm{NO}_{2}$ and $\mathrm{NO}$ was obtained by reading the scale of the maximum point of the purple stained layer, where the colorimetric reaction occurs in the presence of $\mathrm{NO}_{2}$ or $\mathrm{NO}$ :

$$
\begin{gathered}
\mathrm{NO}+\mathrm{CrO}_{3}+\mathrm{H}_{2} \mathrm{SO}_{4} \rightarrow \mathrm{NO}_{2} \\
\mathrm{NO}_{2}+3,3 \text { '-Dimethylnaphithidine } \rightarrow \text { Nitroso-compound (pale purple) }
\end{gathered}
$$

\subsection{Quantification of $\mathrm{N}_{2} \mathrm{O}$}

The concentration of $\mathbf{N}_{2} \mathbf{O}$ in the outlet gas of the reactor was analyzed by an off-line GC equipped with an electron capture detector. The calibration curve of $\mathrm{N}_{2} \mathrm{O}$ was established by testing the standard gases in the range of 0.1-300 ppm. The outlet gas from the reactor was collected in sample bags (FlexFoil PLUS, SKC, Inc) and injected into GC for analysis.

\subsection{Quantification of $\mathrm{NH}_{4}^{+}$}

$\mathrm{NH}_{4}{ }^{+}$was quantified by indophenol blue colorimetry. ${ }^{15-16}$ Three reagents were prepared, including a) coloring solution, containing $0.4 \mathrm{M}$ sodium salicylate and $0.32 \mathrm{M} \mathrm{NaOH}$; b) oxidizing solution, containing $0.75 \mathrm{M} \mathrm{NaOH}$ in $\mathrm{NaClO}$ solution (available chlorine: 4.00-4.99\%); and c) catalyst solution, containing $10 \mathrm{mg} \mathrm{mL}^{-1}$ of $\mathrm{Na}_{2}\left[\mathrm{Fe}(\mathrm{CN})_{5} \mathrm{NO}\right] \cdot 2 \mathrm{H}_{2} \mathrm{O}$. Specifically, $50 \mu \mathrm{L}$ of the 
oxidizing solution, $500 \mu \mathrm{L}$ of the coloring solution, and $50 \mu \mathrm{L}$ of the catalyst solution were added sequentially into $4 \mathrm{~mL}$ of the testing sample, followed by ultrasonication for $10 \mathrm{~s}$ to mix the reagents. The absorbance measurement was performed on a UV-Vis spectrophotometer (Shimadzu UV-2700) at a wavelength of $665 \mathrm{~nm}$ after $2 \mathrm{~h}$ of color development. The calibration curves (Figure S5) were established by examining a series of standard $\mathrm{NH}_{4}{ }^{+}$solutions in the concentration range of 5-300 $\mu \mathrm{M}$. It should be noted that $\mathrm{NH}_{4}{ }^{+}$quantification by colorimetry is $\mathrm{pH}$-sensitive. Therefore, multiple calibration curves were prepared according to the specific composition of the sample solutions. For the $\mathrm{CO}_{2}$-saturated solutions, the $\mathrm{pH}$ was adjusted to 13 by adding $\mathrm{KOH}$ before the colorimetric test.

\subsection{Quantification of $\mathrm{NH}_{2} \mathrm{OH}$}

$\mathbf{N H}_{2} \mathrm{OH}$ was determined by a colorimetric method. ${ }^{17} 1 \mathrm{~mL}$ of the sample solution, $1 \mathrm{~mL}$ of $0.05 \mathrm{M}$ phosphate buffer solution ( $\mathrm{pH}=6.8), 0.8 \mathrm{~mL}$ of DI water, $0.2 \mathrm{~mL}$ of trichloroacetic acid, $1 \mathrm{~mL}$ of 8-quinolinol, and $1 \mathrm{~mL}$ of $1 \mathrm{M} \mathrm{Na}_{2} \mathrm{CO}_{3}$ solution were mixed and placed in a boiling water bath for $1 \mathrm{~min}$ for color development. The solution was then removed from the water bath and cooled at room temperature for $15 \mathrm{~min}$. The absorbance was measured at $705 \mathrm{~nm}$ on a UV-Vis spectrophotometer. The calibration curve (Figure S5) was established by testing a series of $\mathrm{NH}_{2} \mathrm{OH}$ solutions in the concentration range of 6-40 $\mu \mathrm{M}$.

\subsection{Quantification of ${ }^{14} \mathrm{NH}_{4}{ }^{+}$and ${ }^{15} \mathrm{NH}_{4}{ }^{+}$}

${ }^{14} \mathrm{NH}_{4}{ }^{+}$and ${ }^{15} \mathrm{NH}_{4}{ }^{+}$were quantified by ${ }^{1} \mathrm{H}$ nuclear magnetic resonance (NMR) spectroscopy obtained on a Bruker Avance III 600 Spectrometer. Samples were prepared by properly diluting the electrolyte with a solution containing $0.1 \mathrm{M} \mathrm{H}_{2} \mathrm{SO}_{4}$ and $0.1 \mathrm{M} \mathrm{KCl}$, and then mixing $0.8 \mathrm{~mL}$ of the diluted solution with $0.2 \mathrm{~mL}$ of DMSO- $\mathrm{d}_{6}$. Calibration curves were established by testing a series of solutions containing ${ }^{14} \mathrm{NH}_{4}{ }^{+}$and ${ }^{15} \mathrm{NH}_{4}{ }^{+}$in $0.1 \mathrm{M} \mathrm{H}_{2} \mathrm{SO}_{4}$ and 0.1 $\mathrm{M} \mathrm{KCl}$ with concentrations ranging from 5 to $80 \mu \mathrm{M}$ (Figure S7). The scan number was 2,048. Water suppression was performed for all NMR measurements.

\section{Materials characterization}

\subsection{Physical characterization}

To physical characterization of materials, X-ray diffraction (XRD) crystallography was carried out on a Siemens D500 X-ray diffractometer with a $\mathrm{Cu} \mathrm{K} \alpha$ source $(\lambda=1.5418 \AA)$ at a tube voltage of $45 \mathrm{kV}$ and a tube current of $30 \mathrm{~mA}$. The scan was performed at a rate of $10^{\circ} \mathrm{min}^{-1}$ and a step size of $0.01^{\circ}$. X-ray photoelectron spectroscopy (XPS) was carried out on a Kratos Amicus/ESCA $3400 \mathrm{X}$-ray photoelectron spectrometer with $\mathrm{Mg} \mathrm{K} \alpha \mathrm{X}$-ray (1,253.7 eV). All spectra were calibrated with the $\mathrm{C} 1 \mathrm{~s}$ peak at $284.8 \mathrm{eV}$. Scanning electron microscopy (SEM) was performed on a FEI Quanta-250 field-emission scanning electron microscope. Inductively coupled plasma-optical emission spectroscopy (ICP-OES) was performed on a PerkinElmer $^{\circledR}$ Optima $^{\text {TM }} 8000$ ICP-OES instrument. The calibration in the range of $0.6-100 \mathrm{ppb}$ was established by diluting the standard $\mathrm{Ag}^{+}$solution $\left(1,000 \mu \mathrm{g} \mathrm{mL}{ }^{-1}\right.$, Inorganic Ventures) with $5 \%$ v/v nitric acid. 


\subsection{Determination of the electrochemical active surface area (ECSA)}

The electrochemical active surface area (ECSA) of the Ag electrodes (OD-Ag, Ag foil, and $\mathrm{Ag}$ NPs/Ag) was measured by underpotential deposition (UPD) of $\mathrm{Pb} .{ }^{18}$ Cyclic voltammetry (CV) was conducted in a three-electrode system with an electrolyte consisting of $5 \mathrm{mM} \mathrm{Pb}\left(\mathrm{NO}_{3}\right)_{2}, 10$ $\mathrm{mM} \mathrm{HNO}_{3}$, and $10 \mathrm{mM} \mathrm{KCl}$ between -0.10 and $-0.48 \mathrm{~V}_{\mathrm{Ag} / \mathrm{AgCl}}$ with a scan rate of $10 \mathrm{mV} \mathrm{s}^{-1}$. The peak for monolayer UPD of $\mathrm{Pb}$ was used for ECSA calculation, which corresponds to a charge of $1.67 \times 10^{-3} \mathrm{~cm}^{2} \mu \mathrm{C}^{-1}$.

\subsection{Determination of the active surface area of $\mathrm{Pd}$}

The active surface area of $\mathrm{Pd}$ for $\mathrm{Pd} / \mathrm{C}$ was measured by $\mathrm{H}_{2}$ pulse chemisorption on an AutoChem II 2920 chemisorption analyzer. The catalyst was first reduced at $200{ }^{\circ} \mathrm{C}\left(10{ }^{\circ} \mathrm{C} \mathrm{min}^{-1}\right.$ ramp rate) under a flow of $10 \% \mathrm{H}_{2} / \mathrm{Ar}\left(50 \mathrm{~mL} \mathrm{~min}^{-1}\right)$ for $1 \mathrm{~h}$. Then, a 1-hour purging step was carried out with $\operatorname{Ar}\left(20 \mathrm{~mL} \mathrm{~min}^{-1}\right)$ at $200{ }^{\circ} \mathrm{C}$ before the catalyst was cooled to $35^{\circ} \mathrm{C}$. After the baseline signal from the thermal conductivity detector was stable, a series of pulse streams of $10 \%$ $\mathrm{H}_{2}$-Ar was injected until the injected gas volume emerged from the sample tube was unchanged and the detected peak integral was constant. The stoichiometric factor for $\mathrm{H}_{2}$ adsorption was assumed to be 2 (one $\mathrm{H}_{2}$ molecule for two Pd atoms). ${ }^{19}$ 


\section{Supplementary Figures (1-33)}

(a)

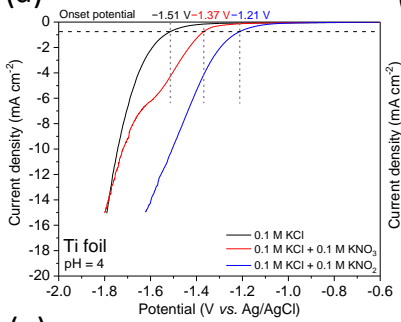

(e)

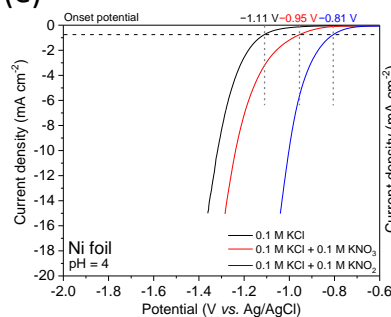

(i)

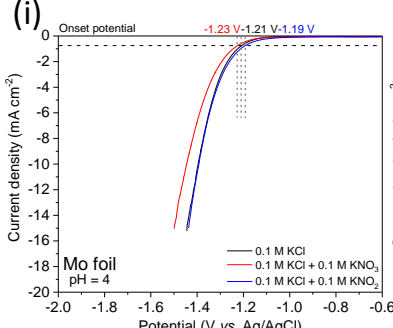

(m)

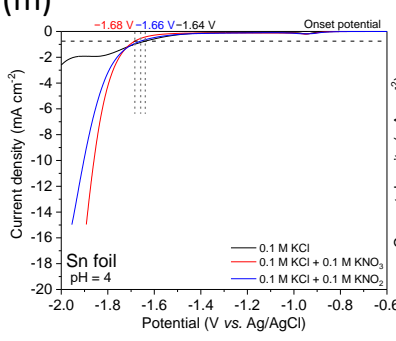

(b)

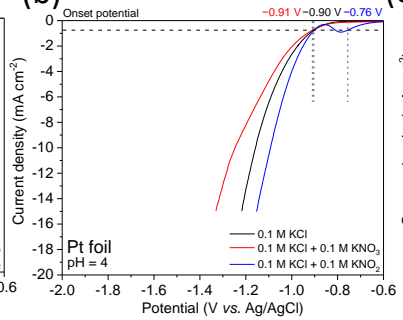

(f)

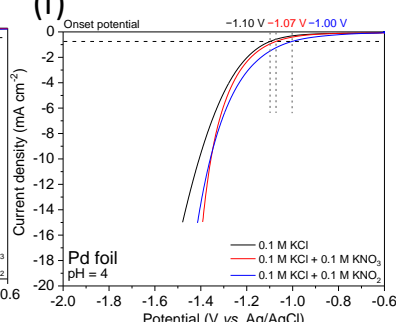

(j)

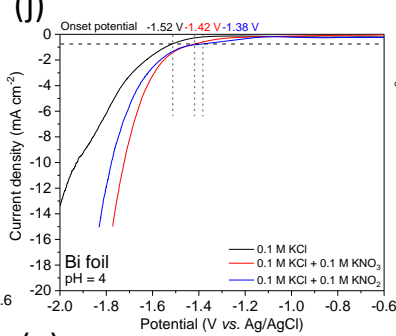

(n)

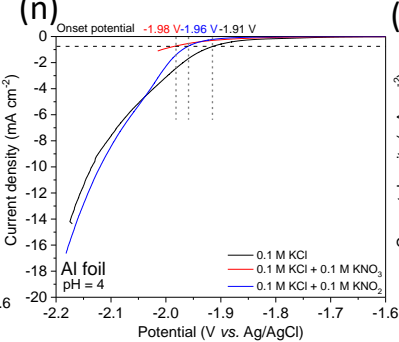

(c)

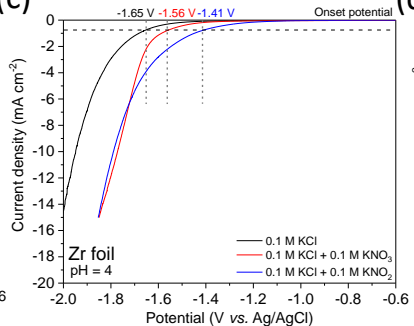

(g)

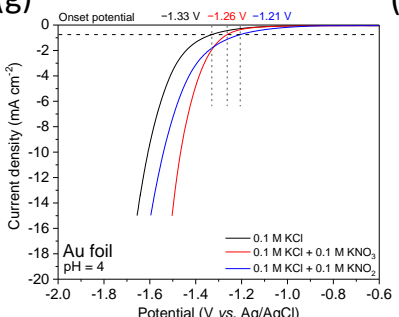

(k)

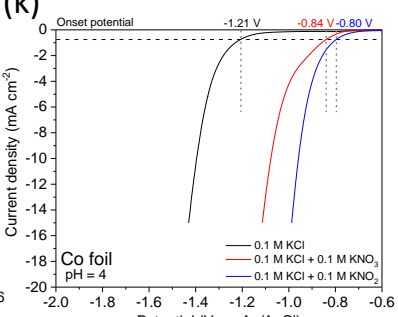

(o)

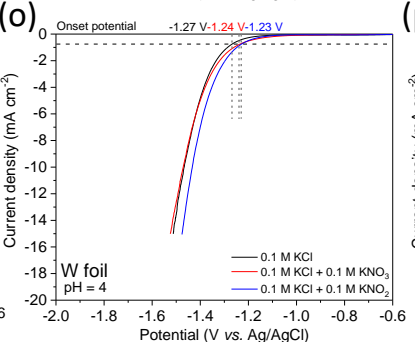

(d)

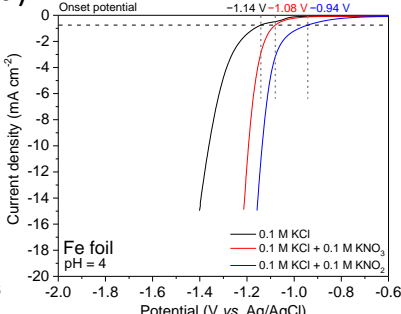

(h)

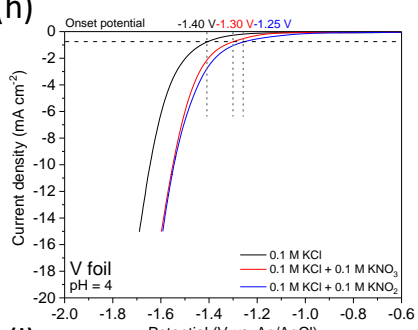

(I)

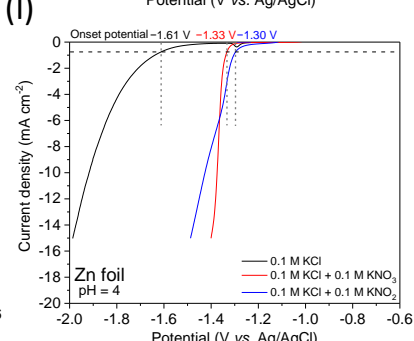

(p)

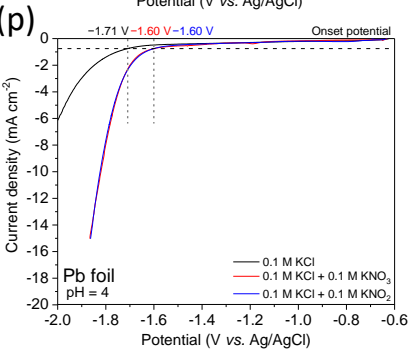

Figure S1. Linear sweep voltammograms of metal foil electrodes. (a)-(p) correspond to the voltammograms Ti, Pt, Zr, Fe, Ni, Pd, Au, V, Mo, Bi, Co, Zn, Sn, Al, W, and $\mathrm{Pb}$ in three different solutions: $0.1 \mathrm{M} \mathrm{KCl}$ (black curves), $0.1 \mathrm{M} \mathrm{KCl}$ with $0.1 \mathrm{M} \mathrm{NO}_{3}{ }^{-}$(red curves), and $0.1 \mathrm{M} \mathrm{KCl}$ with $0.1 \mathrm{M} \mathrm{NO}_{2}^{-}$(blue curves). The onset potentials (defined as the potential at $-0.75 \mathrm{~mA} \mathrm{~cm}^{-2}$ ) of $\mathrm{NO}_{3}{ }^{-}$reduction, $\mathrm{NO}_{2}{ }^{-}$reduction, and HER are labeled on the top of each graph. The geometric area of the electrodes was $4 \mathrm{~cm}^{2}$. The range of $x$-axis in Figure $\mathrm{S} 1 \mathrm{n}(\mathrm{Al}$ foil $)$ is from -1.6 to $-2.2 \mathrm{~V}_{\mathrm{Ag} / \mathrm{AgCl}}$. 
(a)

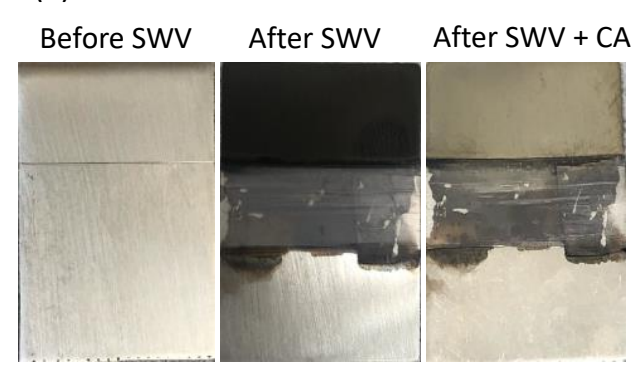

(b)

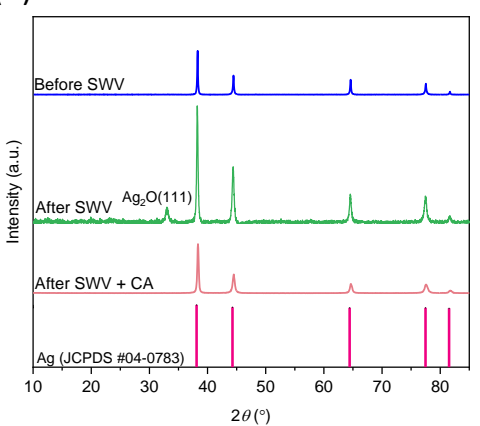

(c)

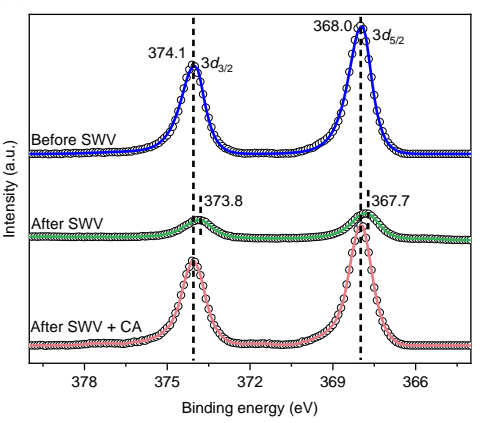

Figure S2. Characterization of Ag foil during the preparation of OD-Ag. (a) Photographs. (b) XRD patterns. (c) XPS Ag $3 d$ spectra. The surface color of Ag foil was observed to periodically change between white and black during the SWV operation, while a yellow surface was finally obtained after the CA operation. These black and yellow layers were $\mathrm{OD}-\mathrm{AgO}_{x}$ and $\mathrm{OD}-\mathrm{Ag}$, respectively. XRD confirms the mono-constituent $\mathrm{Ag}^{0}$ in the prepared OD- $\mathrm{Ag}$ (same as $\mathrm{Ag}$ foil), in comparison to OD- $\mathrm{AgO}_{x}$ possessing the characteristic diffraction plane of $\mathrm{Ag}_{2} \mathrm{O}(111)$ at $32.8^{\circ}$. XPS exhibited a negative shift of $0.3 \mathrm{eV}$ in the binding energy of both $\mathrm{Ag} 3 \mathrm{~d}$ peaks $\left(3 \mathrm{~d}_{3 / 2}\right.$ and $\left.3 \mathrm{~d}_{5 / 2}\right)$ for OD-AgO $\mathrm{O}_{x}$ as compared to $\mathrm{Ag}$ foil and OD-Ag. In addition, $\mathrm{OD}-\mathrm{AgO}_{x}$ has much lower $\mathrm{Ag} 3 \mathrm{~d}$ peak intensity than $\mathrm{Ag}$ foil and $\mathrm{OD}-\mathrm{Ag}$, because of the higher coverage of oxygen atoms on surface. 
(a)

(c)
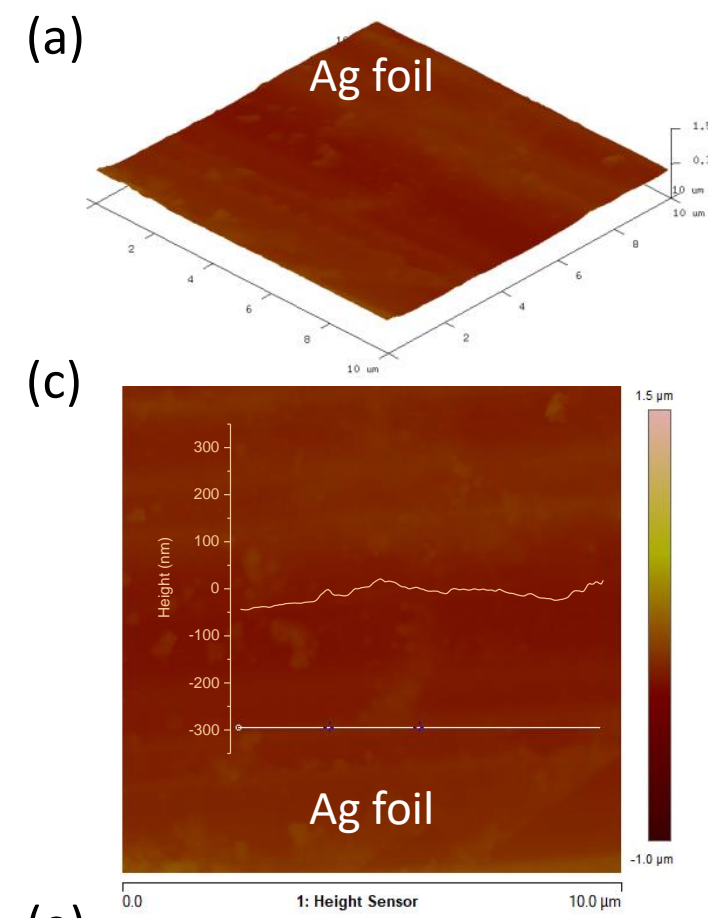

(e)

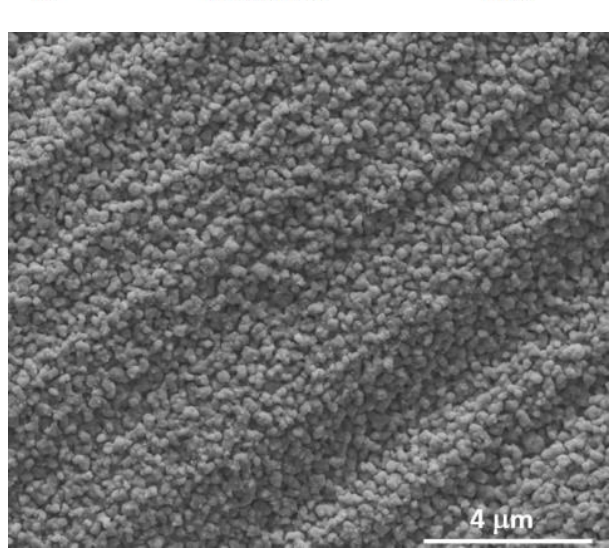

(b)

(d)
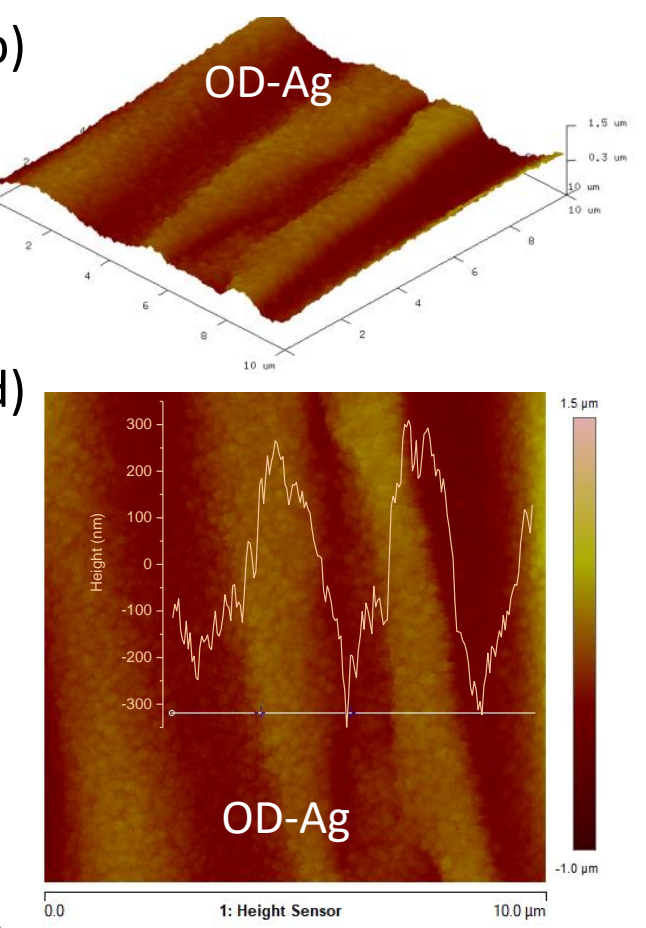

(f)

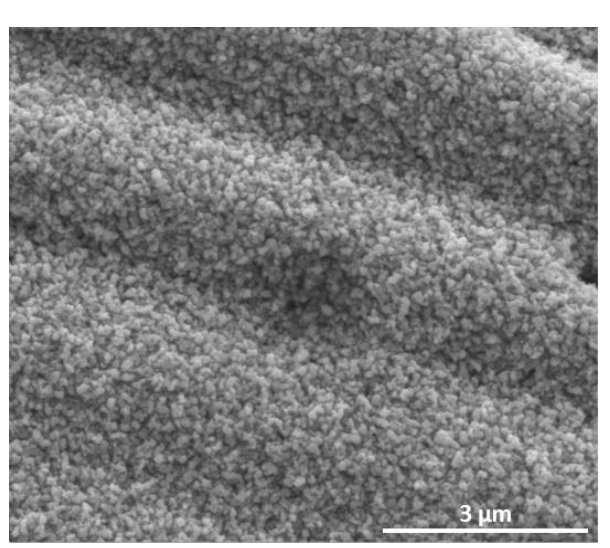

Figure S3. Characterization of the surface morphology of OD-Ag. (a) - (b) AFM 3D images of Ag foil and OD-Ag. (c) - (d) AFM 2D images of Ag foil and OD-Ag with a 7- $\mu$ m section height profile graph inserted. (e) - (f) Low-magnification SEM images of OD-Ag. 
(a)

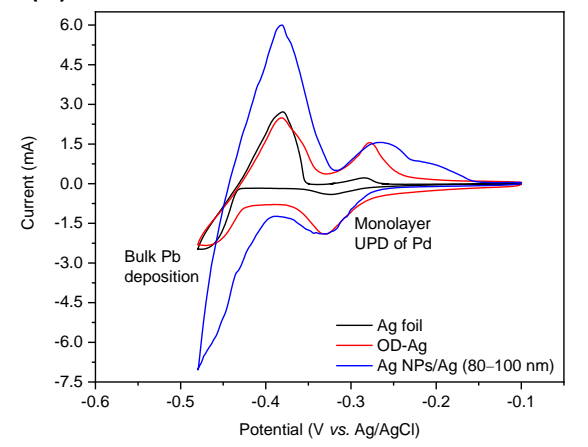

(b)

\begin{tabular}{cccc}
\hline Material & Preparation condition & $\begin{array}{c}\text { Geometric area } \\
\left(\mathrm{cm}^{2}\right)\end{array}$ & ECSA $\left(\mathrm{cm}^{2}\right)$ \\
\hline Ag foil & N/A & 2 & 2.1 \\
Ag NPs/Ag $(80-100 \mathrm{~nm})$ & Spray-coating & 2 & 25.9 \\
OD-Ag & SWV + CA & 2 & 27.1 \\
\hline
\end{tabular}

Figure S4. Measurement of ECSA for the Ag electrodes. (a) Cyclic voltammograms of Ag foil, OD-Ag, and $\mathrm{Ag} \mathrm{NPs} / \mathrm{Ag}$ in the electrolyte consisting of $5 \mathrm{mM} \mathrm{Pb}\left(\mathrm{NO}_{3}\right)_{2}, 10 \mathrm{mM} \mathrm{HNO}_{3}$, and $10 \mathrm{mM} \mathrm{KCl}$. The scan rate was $10 \mathrm{mV} \mathrm{s}^{-1}$. The peak for monolayer UPD of $\mathrm{Pb}$ was used for ECSA calculation, which corresponds to a charge of $1.67 \times 10^{-3} \mathrm{~cm}^{2} \mu \mathrm{C}^{-1}{ }^{18}$ (b) Summary of ECSA of the Ag electrodes. 
(a)

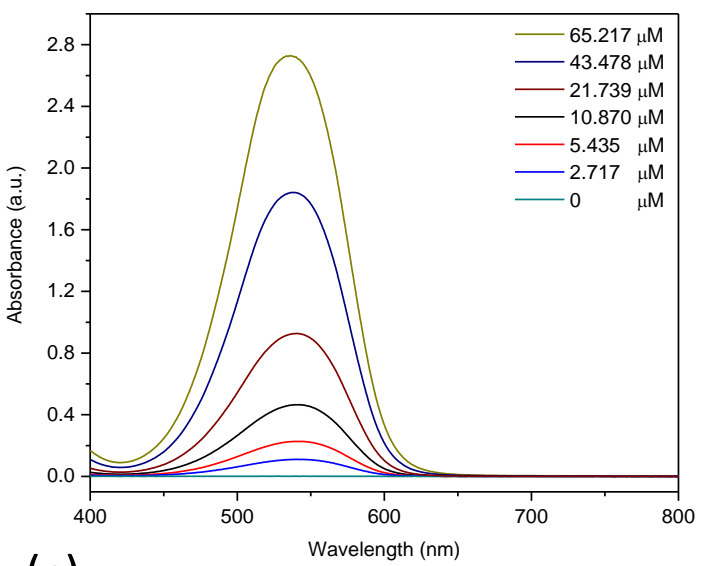

(c)

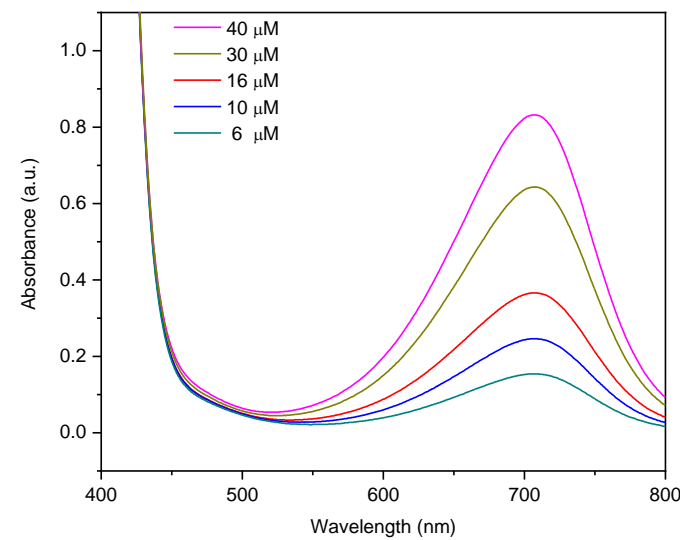

(e)

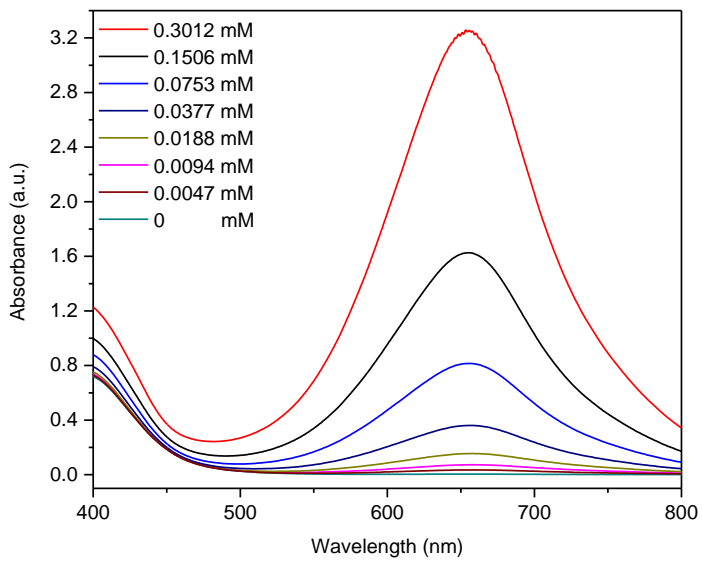

(b)

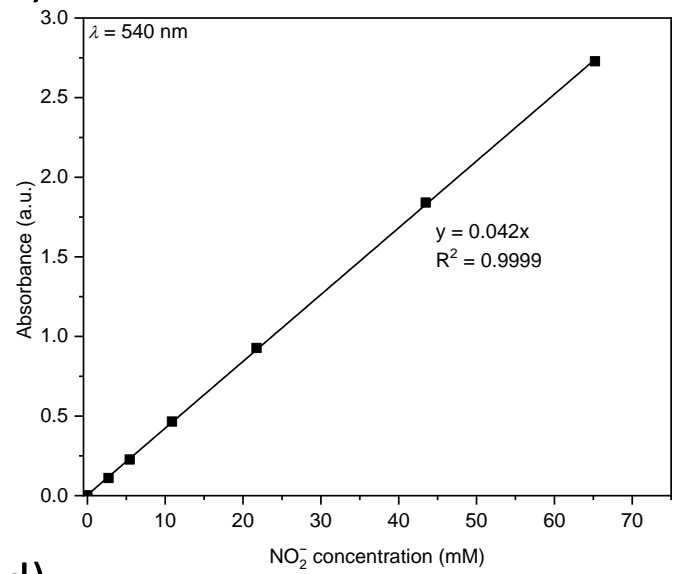

(d)

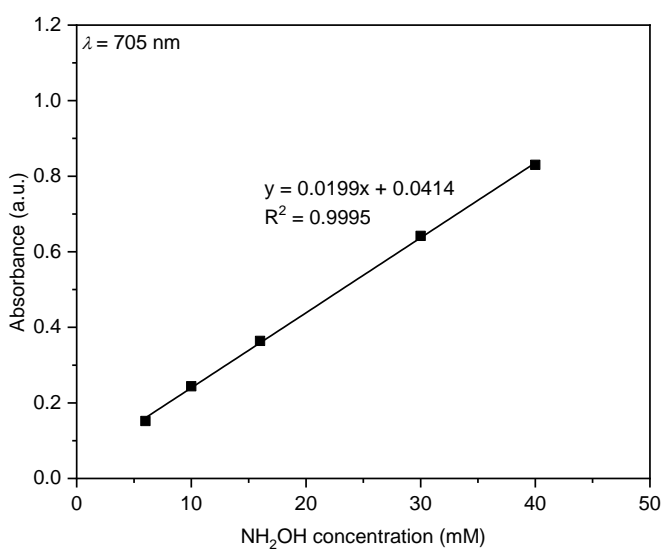

(f)

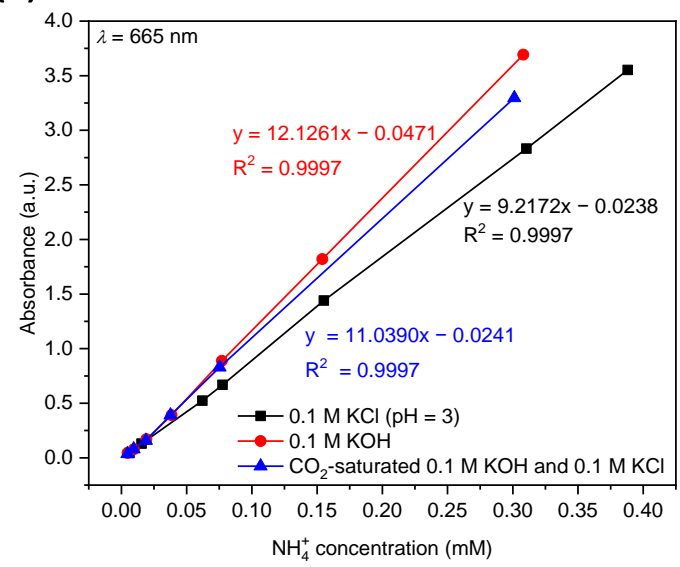

Figure S5. UV-Vis calibrations of $\mathrm{NO}_{2}^{-}, \mathbf{N H}_{2} \mathrm{OH}$, and $\mathrm{NH}_{4}{ }^{+}$. (a) - (b) UV-Vis spectra and calibration curve of standard $\mathrm{NO}_{2}{ }^{-}$solutions. (c) - (d) UV-Vis spectra and calibration curve of standard $\mathrm{NH}_{2} \mathrm{OH}$ solutions. (e) UV-Vis spectra of the standard $\mathrm{NH}_{4}{ }^{+}$solutions in $\mathrm{CO}_{2}$-saturated $0.1 \mathrm{M} \mathrm{KOH}$ and $0.1 \mathrm{M} \mathrm{KCl}$. The $\mathrm{pH}$ of the sample solutions was adjusted to 13 by adding $\mathrm{KOH}$ before the colorimetric test. (f) Calibration curves for standard $\mathrm{NH}_{4}{ }^{+}$solutions in different media. 
(a)

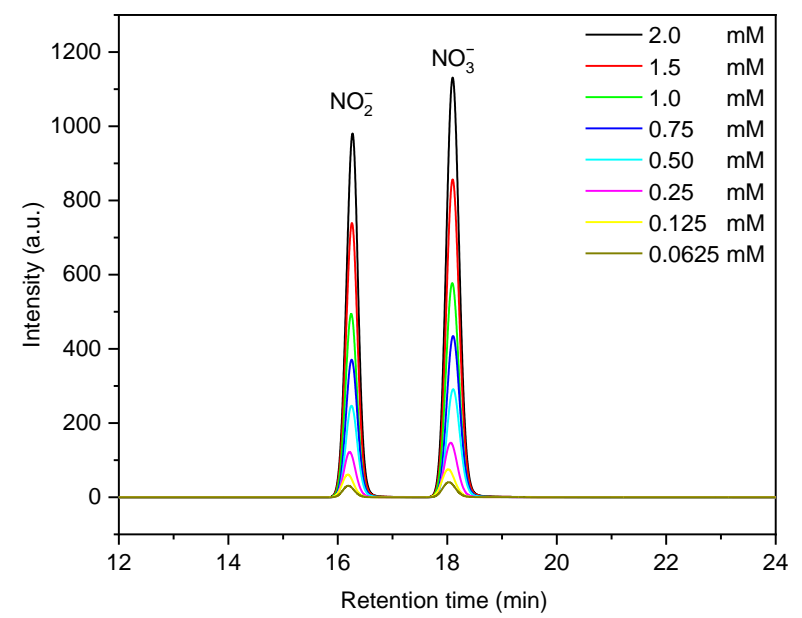

(b)

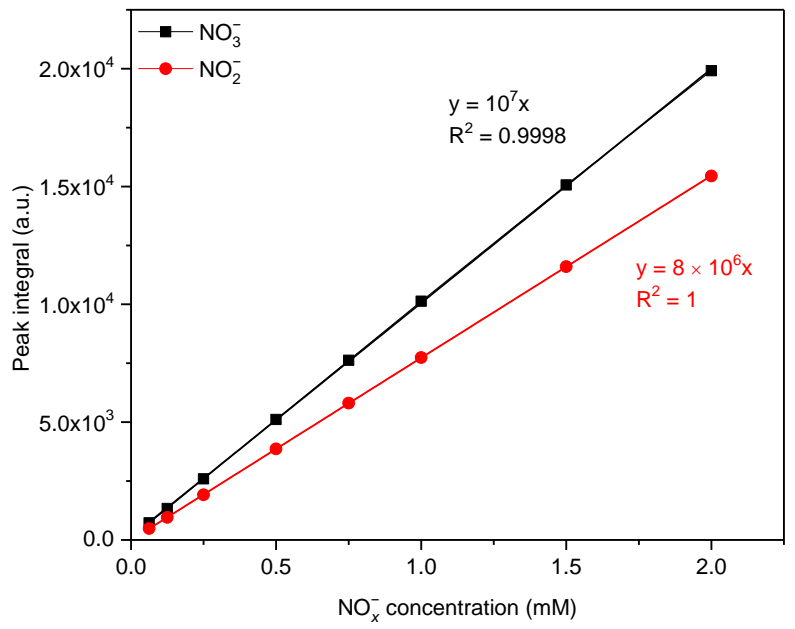

Figure S6. HPLC calibration with standard $\mathrm{NO}_{3}{ }^{-}$and $\mathrm{NO}_{2}{ }^{-}$solutions. (a) HPLC graphs. The retention time was around 16 or 18 min for $\mathrm{NO}_{2}^{-}$or $\mathrm{NO}_{3}^{-}$, respectively. (b) Calibration curves.

(a)

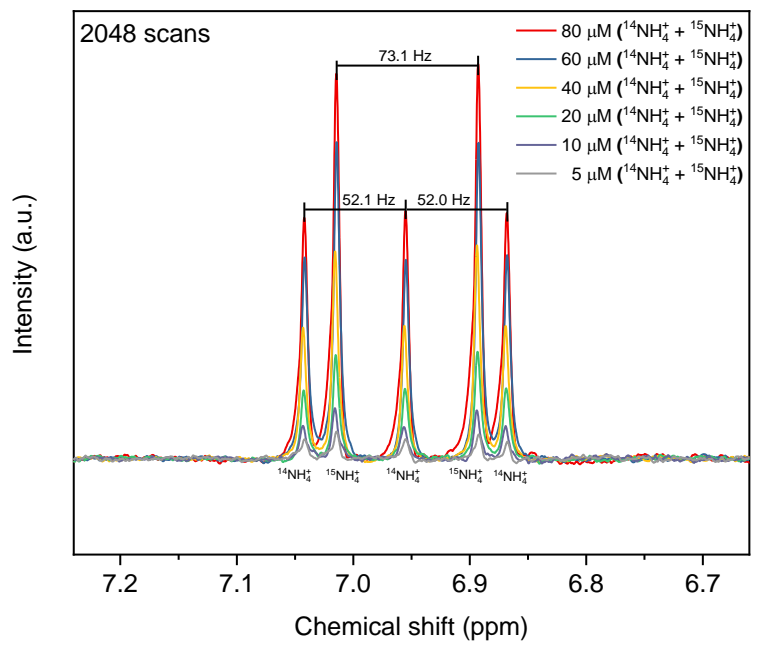

(b)

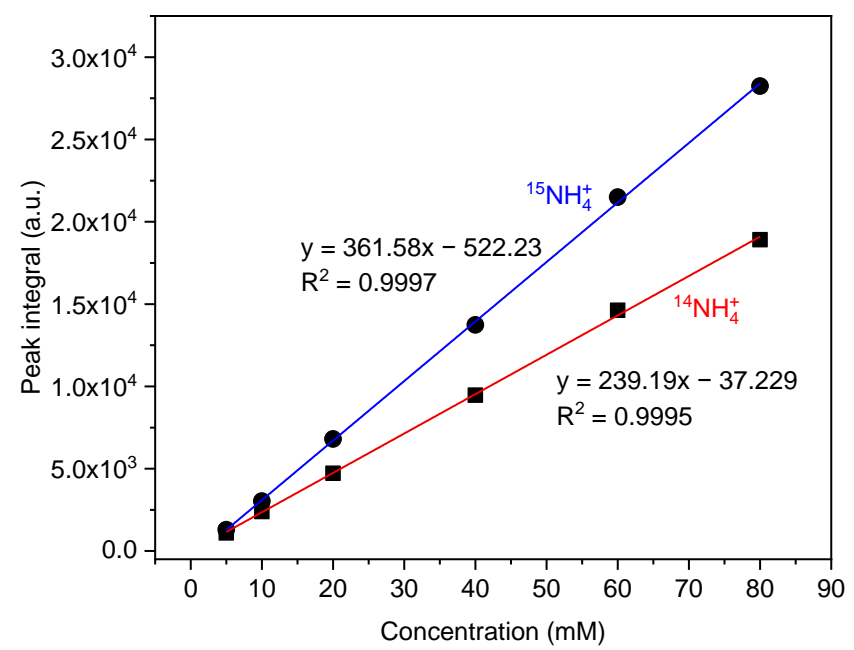

Figure S7. ${ }^{1} \mathrm{H}$ NMR calibration with solutions containing ${ }^{14} \mathrm{NH}_{4}{ }^{+}$and ${ }^{15} \mathrm{NH}_{4}{ }^{+}($in $0.1 \mathrm{M}$ KCl with 0.1 $\mathbf{M ~ H}_{2} \mathbf{S O}_{4}$ ). (a) ${ }^{1} \mathrm{H}$ NMR spectra collected with 2,048 scans. (b) Calibration curves of ${ }^{14} \mathrm{NH}_{4}{ }^{+}$and ${ }^{15} \mathrm{NH}_{4}{ }^{+}$. 


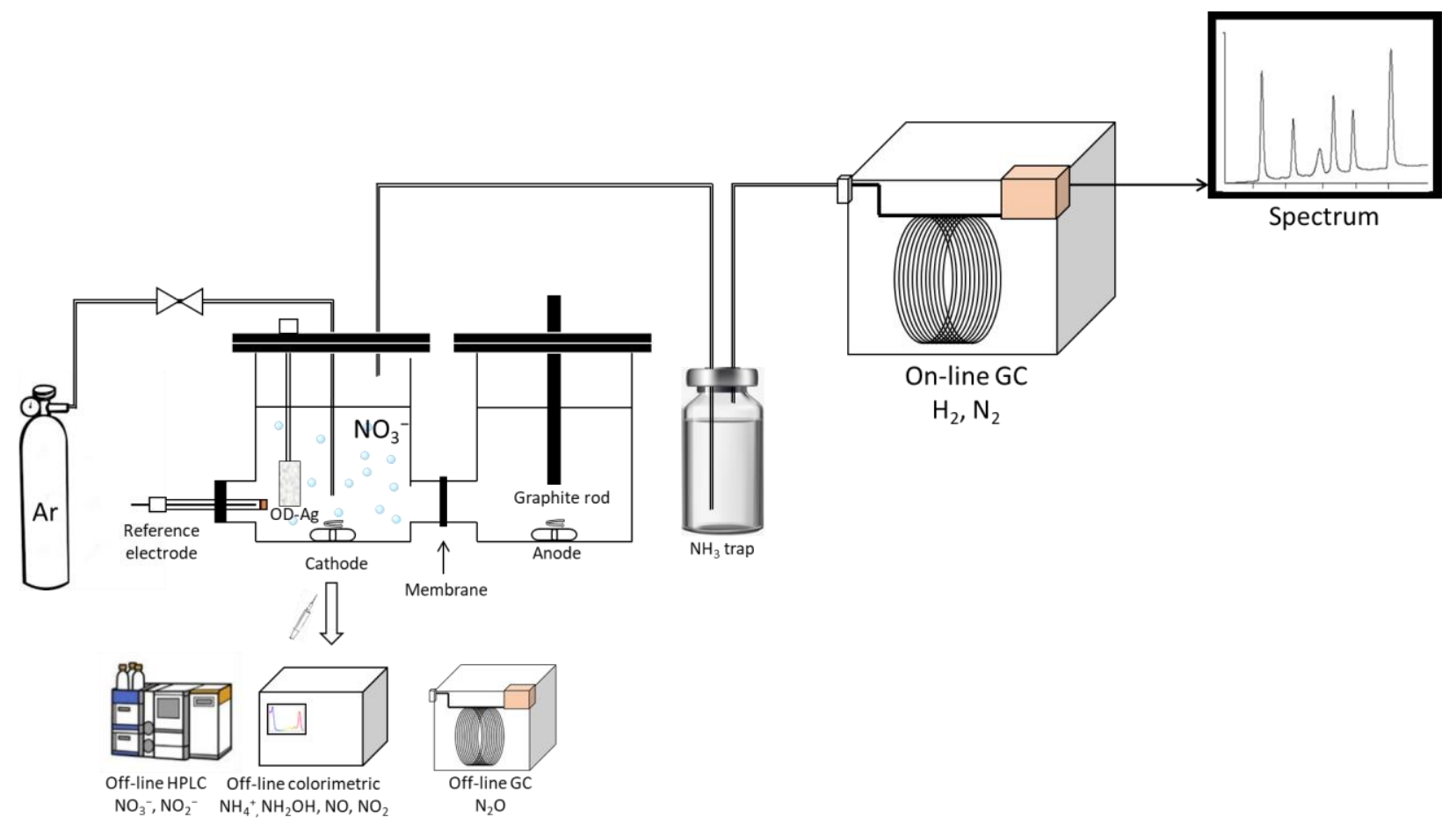

Figure S8. The experimental setup for NO3RR measurements. The setup includes the H-type cell, $\mathrm{NH}_{3}$ trapping solution, on-line $\mathrm{GC}$ for $\mathrm{H}_{2}$ and $\mathrm{N}_{2}$ quantification, and off-line quantification of $\mathrm{NO}_{3}{ }^{-}, \mathrm{NO}_{2}{ }^{-}, \mathrm{NH}_{4}{ }^{+}$, $\mathrm{NH}_{2} \mathrm{OH}, \mathrm{NO}_{2}, \mathrm{NO}$, and $\mathrm{N}_{2} \mathrm{O}$.

(a)

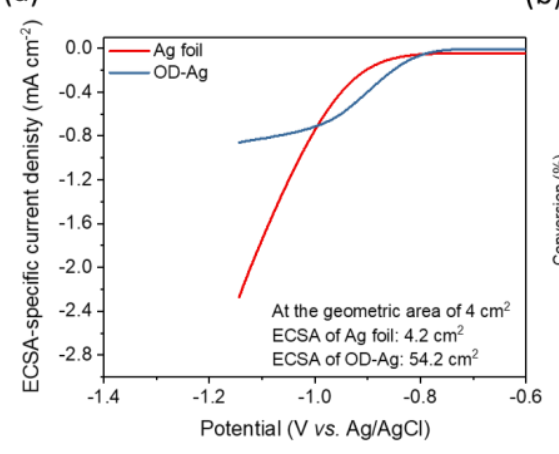

(b)

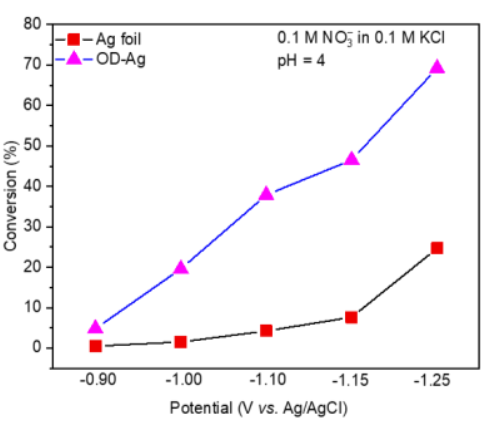

(c)

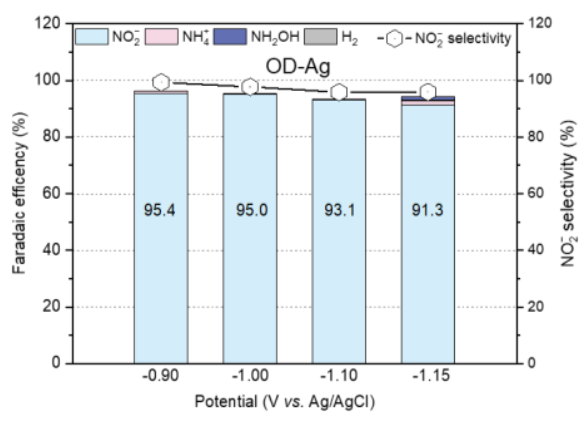

Figure S9. NO3RR in 0.1 M KCl $(\mathrm{pH}=4)$ with $0.1 \mathrm{M} \mathrm{NO}_{3}{ }^{-}$. The geometric area of all electrodes was 4 $\mathrm{cm}^{2}$. (a) ECSA-specific LSV on Ag foil (red curve) and OD-Ag (blue curve) in $0.1 \mathrm{M} \mathrm{KCl}$ with $0.1 \mathrm{M} \mathrm{NO}_{3}{ }^{-}$ at $\mathrm{pH}$ 4. The ECSA for Ag foil and OD-Ag were 4.2 and $54.2 \mathrm{~cm}^{2}$, respectively. (b) Conversion of $\mathrm{NO}_{3}{ }^{-}$ on Ag foil and OD-Ag for 1-hour electrolysis at different potential. (c) $\mathrm{FE}$ and $\mathrm{NO}_{2}{ }^{-}$selectivity on $\mathrm{OD}-\mathrm{Ag}$ for 1-hour electrolysis at different potential.

As shown in Figure S9a, the ECSA-specific current density for OD-Ag has outperformed Ag foil in the potential range ocf -0.8 to $-1.0 \mathrm{~V}$. Under potentials more negative than $-1.0 \mathrm{~V}$, the reaction on $\mathrm{OD}-\mathrm{Ag}$ is more likely to be limited by the mass transport due to its large surface area (ECSA of OD-Ag vs. Ag foil: $54.2 \mathrm{vs} .4 .2 \mathrm{~cm}^{2}$, at the geometric area of $4 \mathrm{~cm}^{2}$ ). LSV is a transient potential sweep process carried out without the magnetic stirring of electrolyte, and thus mass transport of both reactant supply and product giveaway becomes limited due to large current demand under potentials more negative than $-1.0 \mathrm{~V}$. 
(a)

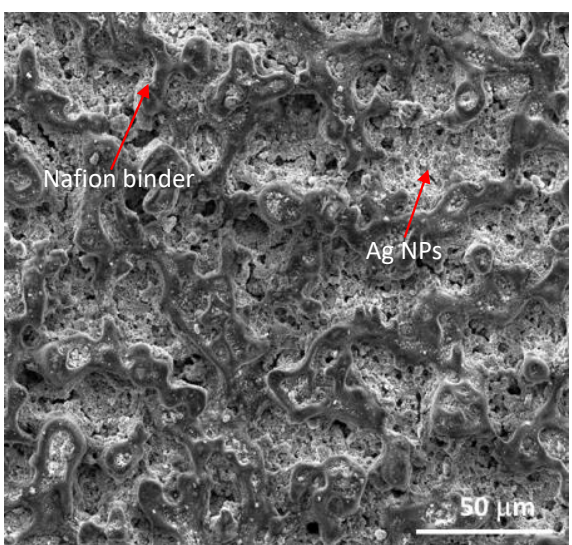

(c)

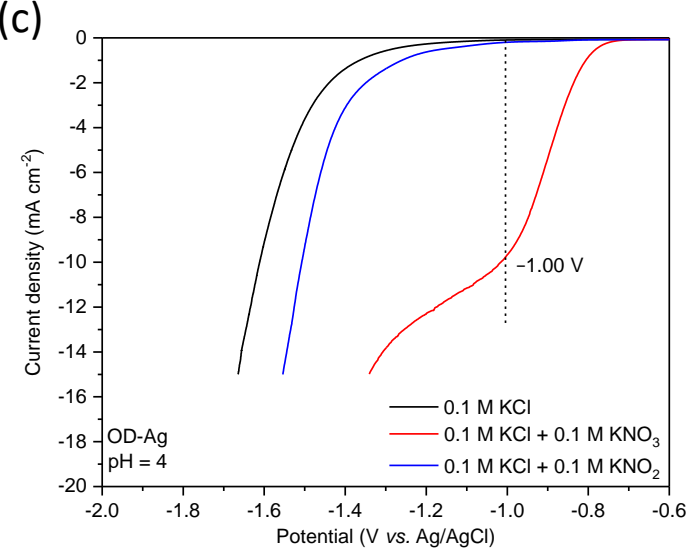

(b)

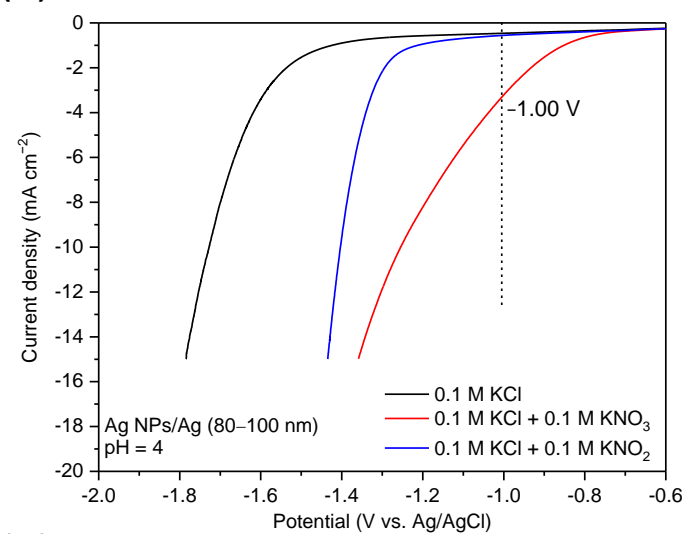

(d)

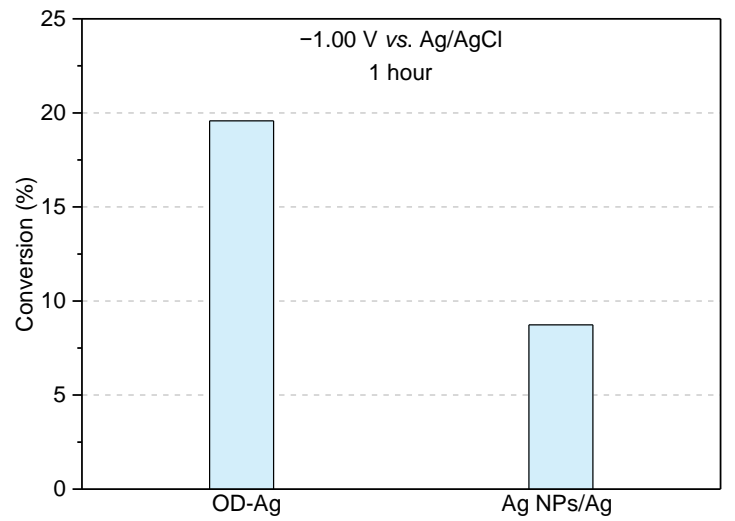

(e)

\begin{tabular}{ccccc}
\hline Electrode & $\begin{array}{c}\text { Geometric } \\
\text { area }\left(\mathrm{cm}^{2}\right)\end{array}$ & $\begin{array}{c}\text { ECSA } \\
\left(\mathrm{cm}^{2}\right)\end{array}$ & $\begin{array}{c}\text { Current @-1.00 V } \\
(\mathrm{mA})\end{array}$ & $\begin{array}{c}\text { ECSA-specific current } \\
\text { density }\left(\mathrm{mA} \mathrm{cm}^{-2}\right)\end{array}$ \\
\hline Ag NPs/Ag (80-100nm) & 4 & 51.80 & -13.44 & 0.26 \\
OD-Ag & 4 & 54.20 & -38.80 & 0.72 \\
\hline
\end{tabular}

Figure S10. Comparison of OD-Ag and Ag NPs/Ag (80-100 $\mathbf{~ m}$, loading of $1.5 \mathbf{m g}_{\mathrm{Ag}} \mathbf{~ c m}^{-2}$. (a) SEM image of Ag NPs/Ag (with Nafion as the binder). (b) - (c) Linear sweep voltammograms in $0.1 \mathrm{M} \mathrm{KCl}, 0.1$ $\mathrm{M} \mathrm{KCl}$ with $0.1 \mathrm{M} \mathrm{NO}_{3}{ }^{-}$, and $0.1 \mathrm{M} \mathrm{KCl}^{-}$with $0.1 \mathrm{M} \mathrm{NO}_{2}{ }^{-}$, respectively. (d) $\mathrm{NO}_{3}{ }^{-}$conversion in $0.1 \mathrm{M} \mathrm{KCl}$ $(\mathrm{pH}=4)$ with $0.1 \mathrm{M} \mathrm{NO}_{3}{ }^{-}$at $-1.00 \mathrm{~V}_{\mathrm{Ag} / \mathrm{AgCl}}$ for $1 \mathrm{~h}$. (e) Summary of area-specific NO3RR activity). It should be pointed out that both OD-Ag and Ag NPs have a similar average size of Ag particles ( $100 \mathrm{~nm} v s .80$ $100 \mathrm{~nm})$, very close ESCA $\left(27.1 \mathrm{~cm}^{2}\right.$ vs. $25.9 \mathrm{~cm}^{2}$, Figure $\left.\mathbf{S 4 b}\right)$, and with the same sized Ag foil $\left(2 \mathrm{~cm}^{2}\right)$ as electrode substrate. 


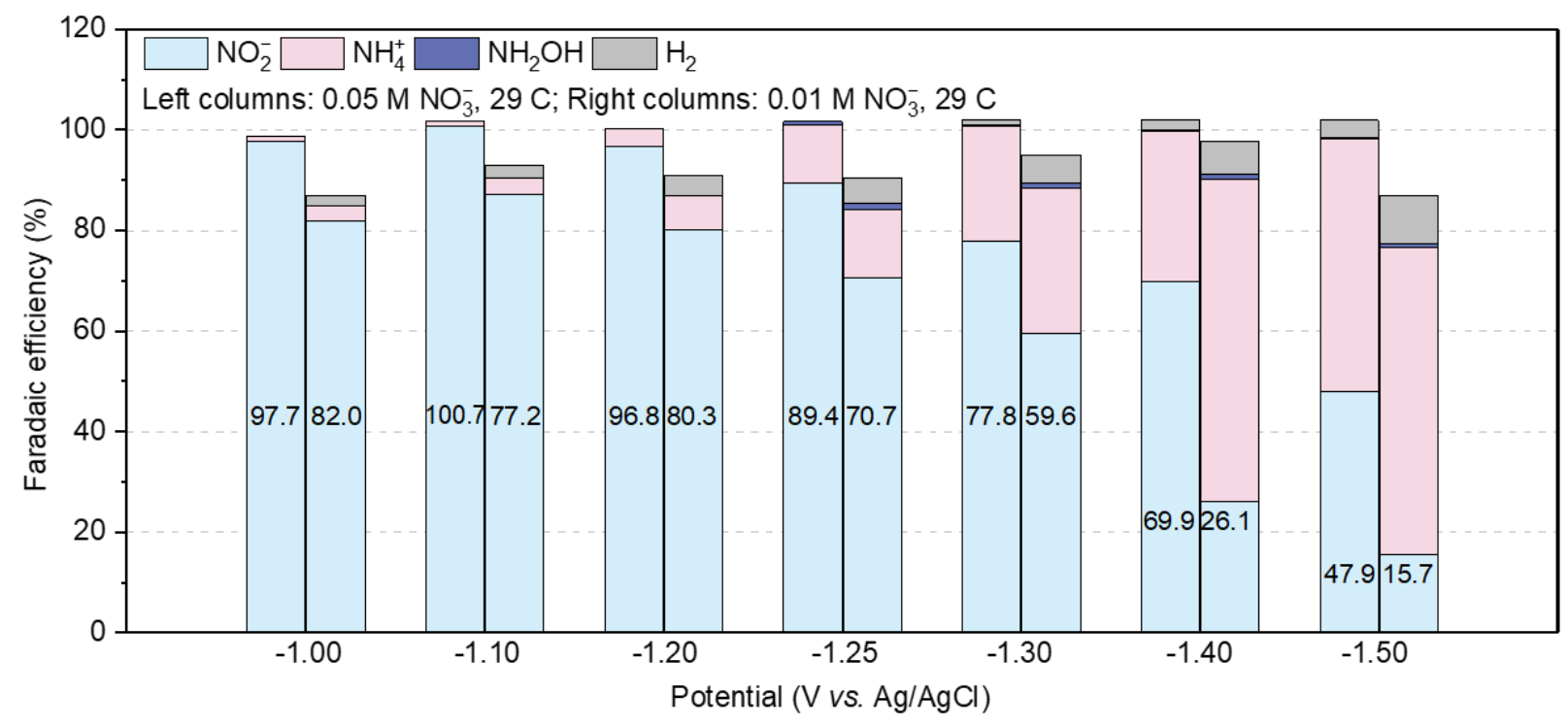

Figure S11. FE of NO3RR on OD-Ag with $0.05 \mathrm{M}$ and $0.01 \mathrm{M} \mathrm{NO}_{3}{ }^{-}$. Left columns: $0.05 \mathrm{M} \mathrm{NO}_{3}{ }^{-}$. Right columns: $0.01 \mathrm{M} \mathrm{NO}_{3}{ }^{-}$. The electrolyte was $0.1 \mathrm{M} \mathrm{KCl}(\mathrm{pH}=4)$. The applied charge was $29 \mathrm{C}$ which is the theoretical charge required for NO3RR to $\mathrm{NO}_{2}{ }^{-}$in the system. The geometric area of the electrode was 6 $\mathrm{cm}^{2}$ for -1.00 and $-1.10 \mathrm{~V}_{\mathrm{Ag} / \mathrm{AgCl}}$ with $0.01 \mathrm{M} \mathrm{NO}_{3}{ }^{-}$, and $2 \mathrm{~cm}^{2}$ for all other conditions. The error bars represent the standard deviation for at least three independent measurements. 


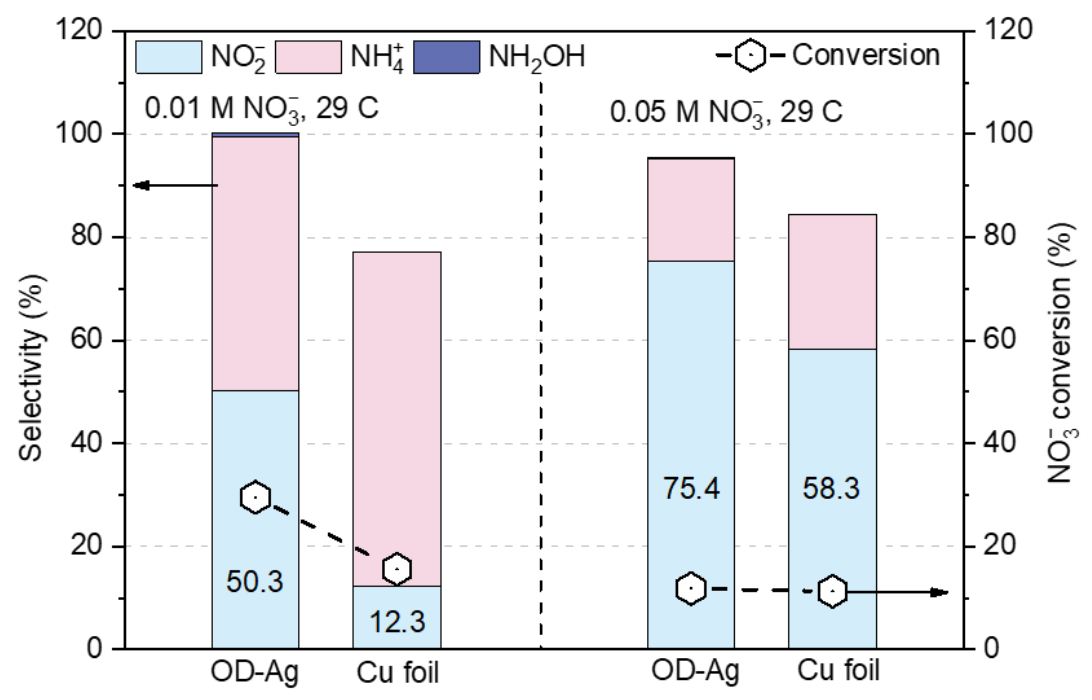

Figure S12. Product selectivity and $\mathrm{NO}_{3}{ }^{-}$conversion of NO3RR on OD-Ag and $\mathrm{Cu}$ foil at -1.50 $\mathbf{V}_{\mathrm{Ag} / \mathrm{AgCl}}$. The electrolyte was $0.1 \mathrm{M} \mathrm{KCl}(\mathrm{pH}=4)$ and the geometric area of the electrodes was $2 \mathrm{~cm}^{2}$. The applied charge was $29 \mathrm{C}$.

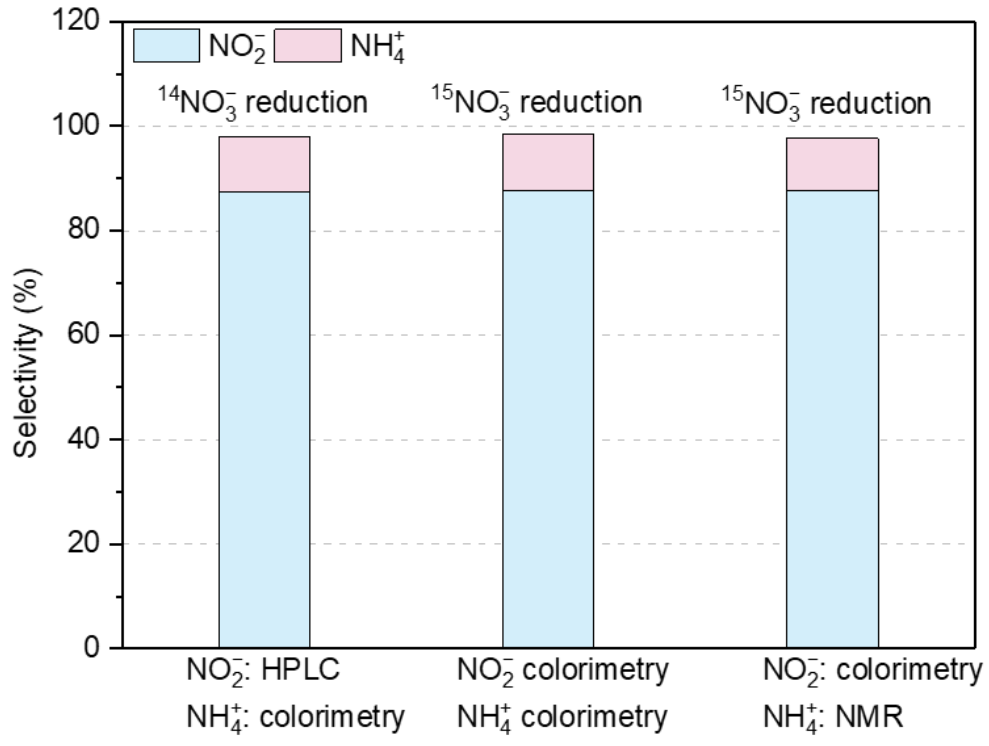

Figure S13. Comparison of different quantification methods. NO3RR was performed in $0.1 \mathrm{M} \mathrm{KCl}$ with $0.01 \mathrm{M}^{14} \mathrm{NO}_{3}{ }^{-}$or ${ }^{15} \mathrm{NO}_{3}{ }^{-}$on OD-Ag. The applied potential was $-1.30 \mathrm{~V}_{\mathrm{Ag} / \mathrm{AgCl}}$ and applied charge was 29 C. The produced $\mathrm{NO}_{2}^{-}$was quantified by high-performance liquid chromatography (HPLC) or Griess colorimetry, and $\mathrm{NH}_{4}{ }^{+}$was quantified by indophenol blue colorimetry or $1 \mathrm{H} \mathrm{NMR}$. 


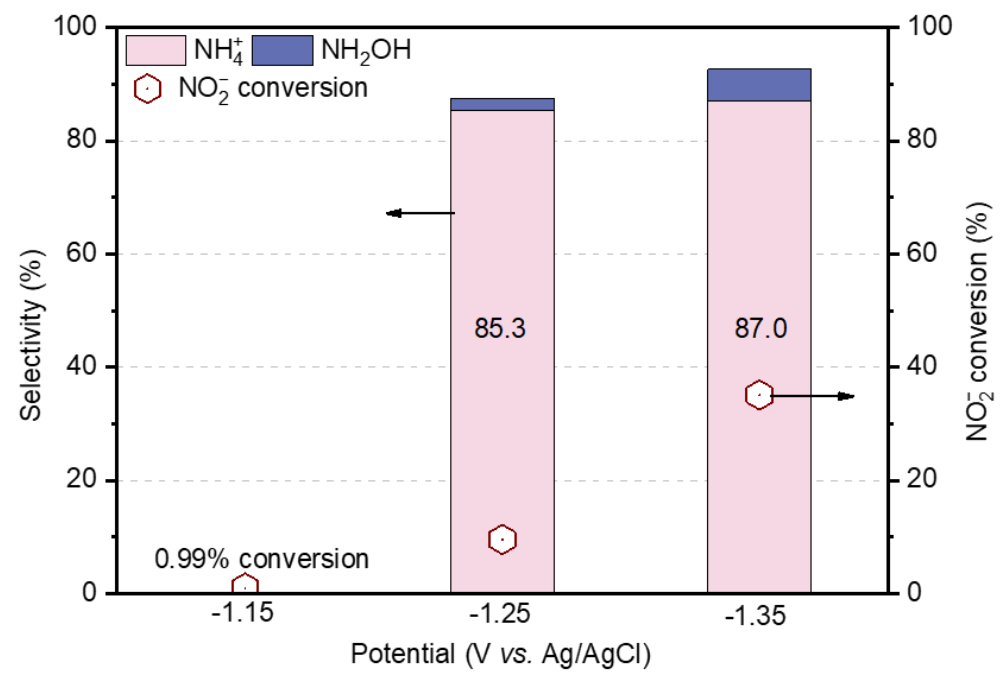

Figure S14. Electrochemical reduction of $0.01 \mathrm{M} \mathrm{NO}_{2}^{-}$on OD-Ag. Product selectivity and $\mathrm{NO}_{2}^{-}$ conversion for 1-hour electrolysis. The electrolyte was $0.1 \mathrm{M} \mathrm{KCl}(\mathrm{pH}=4)$ and the geometric area of ODAg was $2 \mathrm{~cm}^{2}$.

(a)

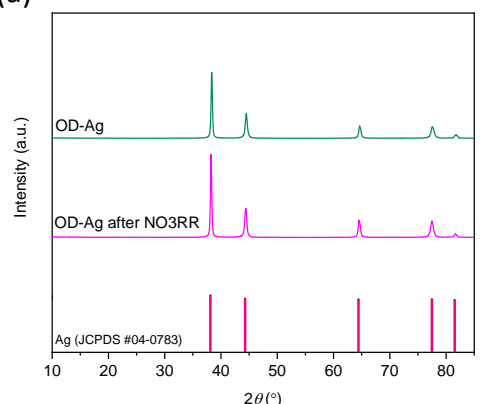

(d) (b)

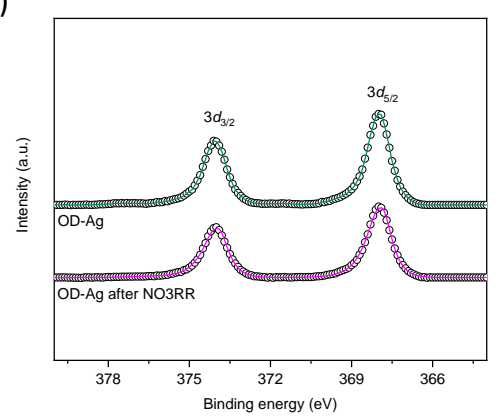

(e)

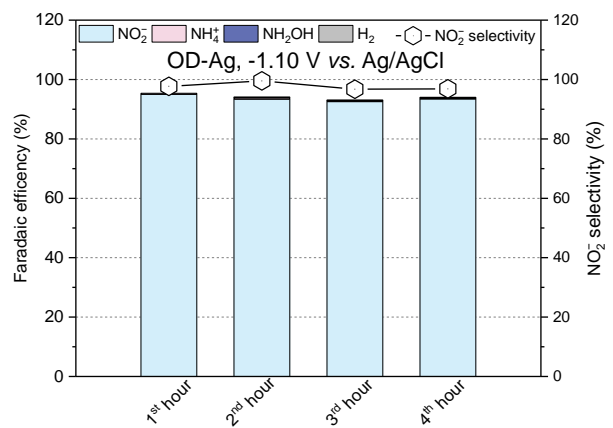

Figure S15. Stability measurements on OD-Ag (geometric area of $\mathbf{4} \mathbf{c m}^{2}$ ) for NO3RR. Electrolysis was performed in $0.1 \mathrm{M} \mathrm{KCl}(\mathrm{pH}=4)$ with $0.1 \mathrm{M} \mathrm{NO}_{3}{ }^{-}$at $-1.00 \mathrm{~V}_{\mathrm{Ag} / \mathrm{AgCl}}$. (a) XRD patterns, (b) XPS Ag $3 d$ spectra, (c) SEM image, and (d) $\mathrm{Ag}^{+}$content in the electrolyte by ICP-OES after 1-hour electrolysis. (e) Faradaic efficiency and $\mathrm{NO}_{2}{ }^{-}$selectivity for four consecutive 1-hour electrolysis on the same OD-Ag. 


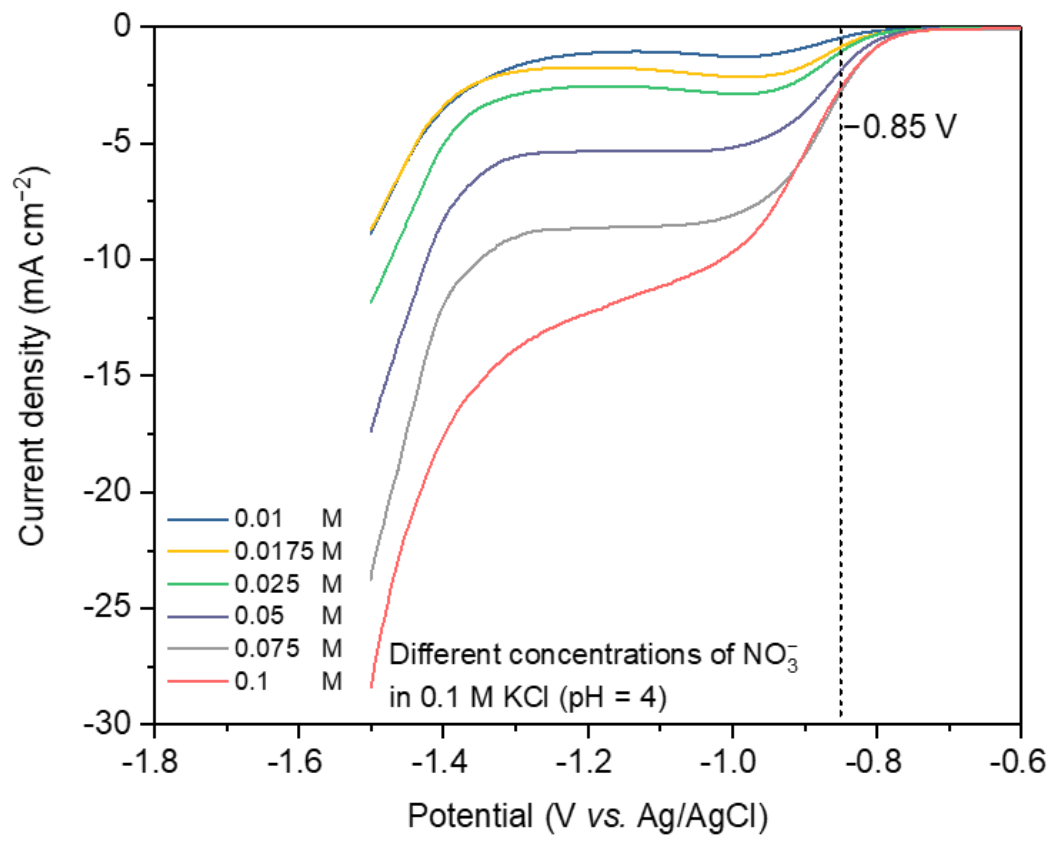

Figure S16. Linear sweep voltammograms of OD-Ag in $0.1 \mathrm{M} \mathrm{KCl}(\mathrm{pH}=4)$ with different concentrations of $\mathrm{NO}_{3}{ }^{-}$. The geometric area of the electrodes was $4 \mathrm{~cm}^{2}$.

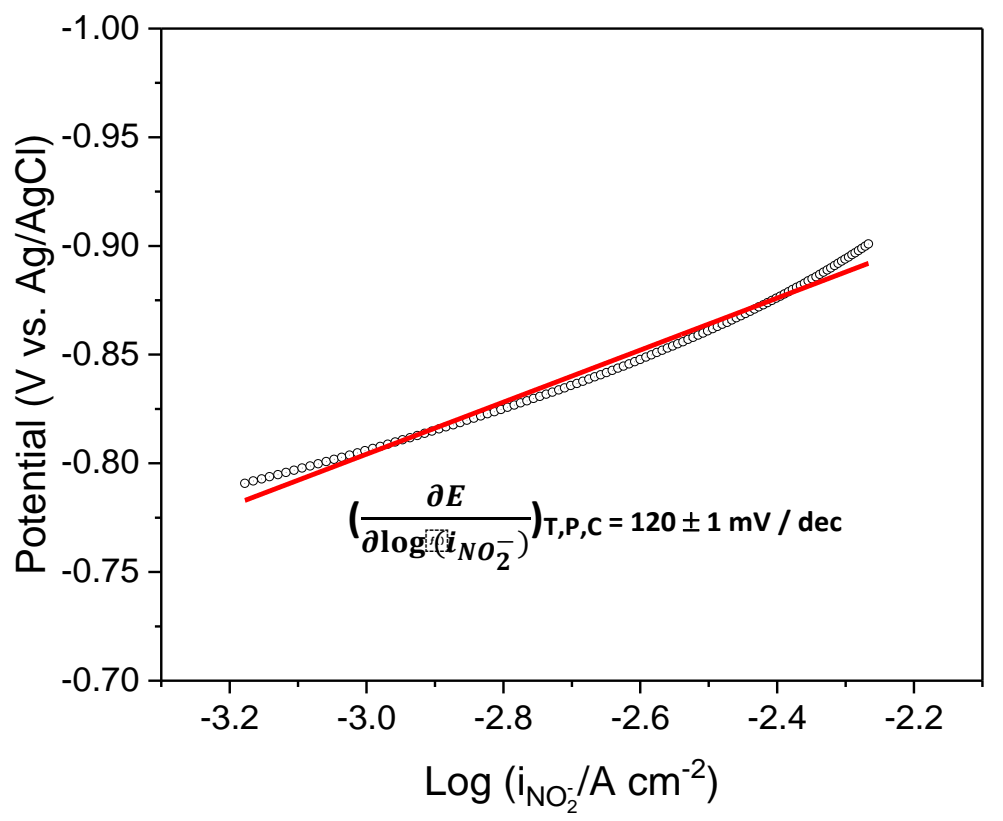

Figure S17. $\mathrm{NO}_{2}^{-}$partial current density Tafel plot. The data was obtained from the Linear sweep voltammograms (LSV) with a potential range from $-0.79 \mathrm{~V}$ (onset potential of NO3RR) to $-0.90 \mathrm{~V}_{\mathrm{Ag} / \mathrm{AgCl}}$.

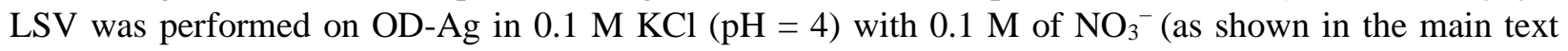
Figure 2c). The geometric area of the electrodes was $4 \mathrm{~cm}^{2}$. 
(a)

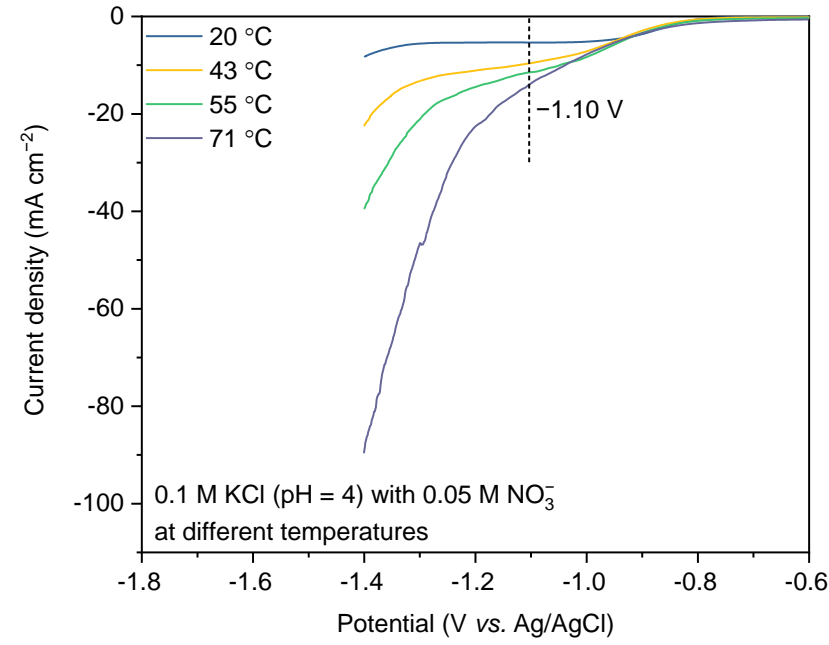

(b)

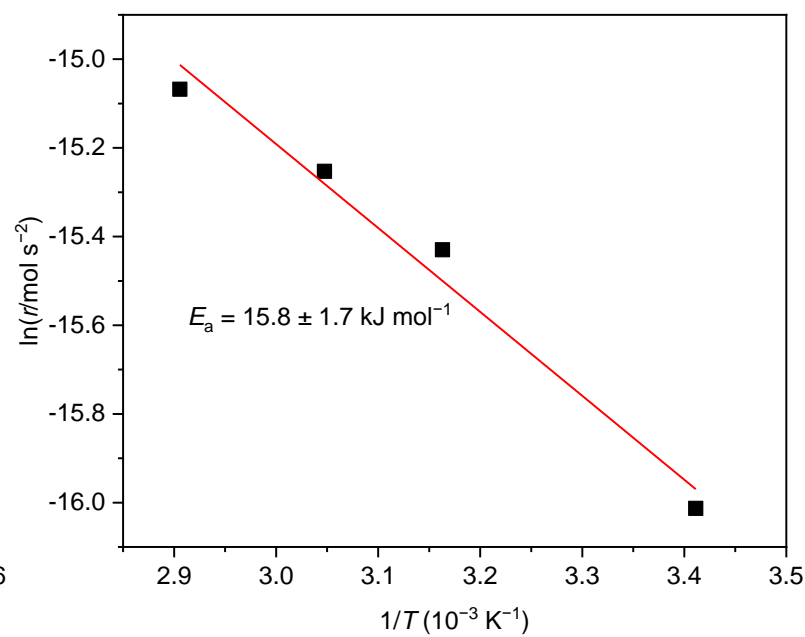

Figure S18. Activation energy for NO3RR on OD-Ag at $\mathbf{- 1 . 1 0} \mathbf{V}_{\mathbf{A g} / \mathbf{A g C l}}$. (a) Linear sweep voltammograms of OD-Ag in $0.1 \mathrm{M} \mathrm{KCl}(\mathrm{pH}=4)$ with $0.05 \mathrm{M} \mathrm{NO}_{3}{ }^{-}$at different temperatures. The geometric area of OD-Ag was $4 \mathrm{~cm}^{2}$. (b) Arrhenius plot for NO3RR on OD-Ag at $-1.10 \mathrm{~V}_{\mathrm{Ag} / \mathrm{AgCl}}$.

(a)

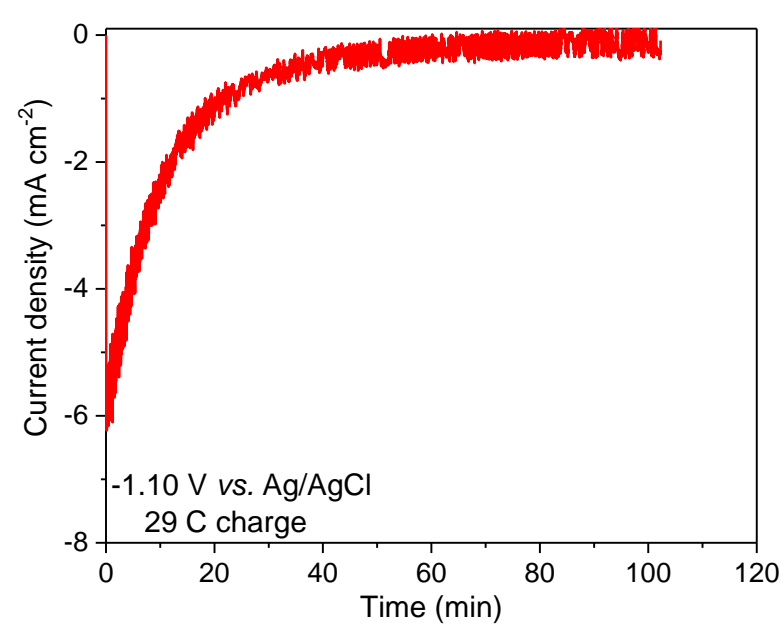

(b)

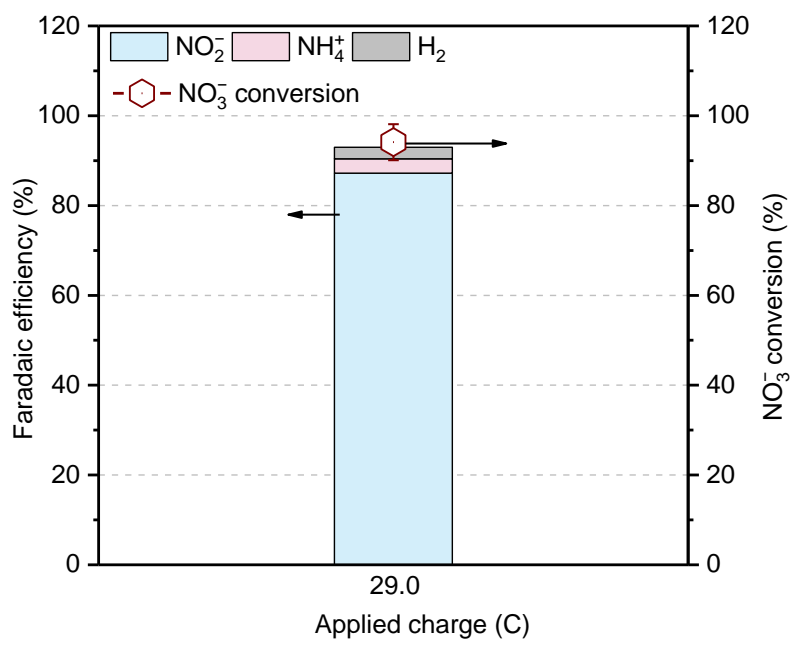

Figure S19. NO3RR on OD-Ag with $29 \mathrm{C}$ applied charge at $-\mathbf{1 . 1 0} \mathbf{~ V}_{\mathrm{Ag} / \mathrm{AgCl}}$. The electrolyte was in 0.1 $\mathrm{M} \mathrm{KCl}(\mathrm{pH}=4)$ with $0.01 \mathrm{M} \mathrm{NO}_{3}{ }^{-}$and the geometric area of OD-Ag was $6 \mathrm{~cm}^{2}$. (a) Current density-time profile with applying a theoretical charge of $29 \mathrm{C}$ for complete convert $0.01 \mathrm{M} \mathrm{NO}_{3}{ }^{-}$to $\mathrm{NO}_{2}{ }^{-}$. (b) Faradaic efficiency and $\mathrm{NO}_{3}{ }^{-}$conversion. The error bars represent the standard deviations of at least three independent measurements. 
(a)

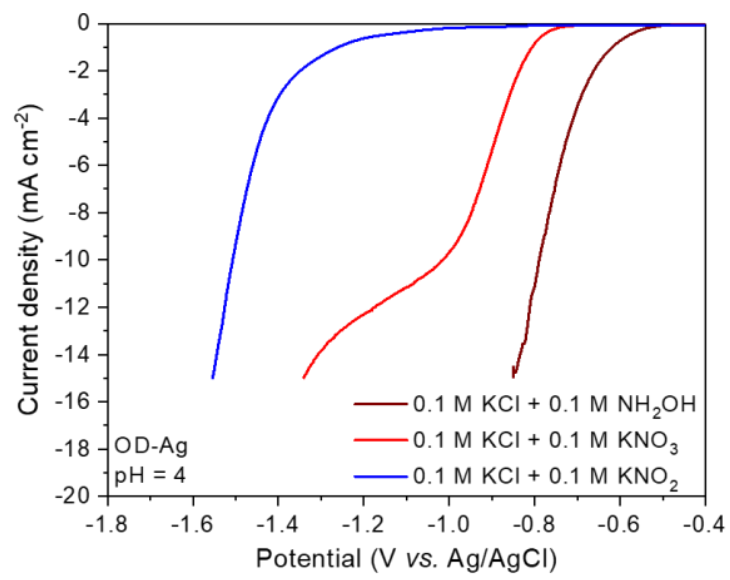

(b)

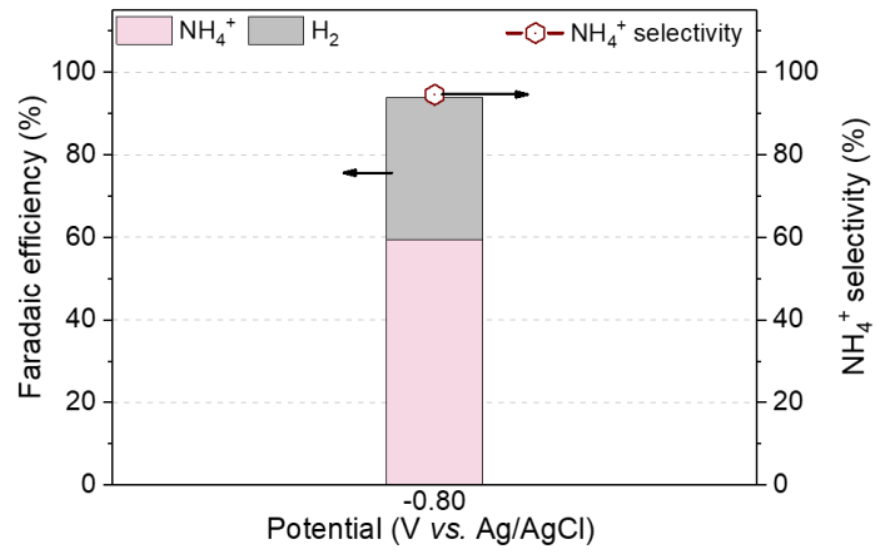

Figure S20. Electrochemical reduction of $\mathrm{NH}_{2} \mathrm{OH}$ on OD-Ag $\left(4 \mathrm{~cm}^{2}\right.$ geometric area) at $\mathrm{pH} 4$. a) Linear sweep voltammetry in $0.1 \mathrm{M} \mathrm{KCl}$ with $0.1 \mathrm{M} \mathrm{NH}_{2} \mathrm{OH}, 0.1 \mathrm{M} \mathrm{KNO}_{3}$, and $0.1 \mathrm{M} \mathrm{KNO}_{2}$, respectively. b) $\mathrm{FE}$ and $\mathrm{NH}_{4}{ }^{+}$selectivity of electrolysis in $0.1 \mathrm{M} \mathrm{KCl}$ with $0.1 \mathrm{M} \mathrm{NH}_{2} \mathrm{OH}$ at $-0.80 \mathrm{~V}_{\mathrm{Ag} / \mathrm{AgCl}}$ for 1 hour. 


\section{Supplementary Note 1. Isotopic experiment and kinetics modeling}

The isotopic experiment was conducted in $0.1 \mathrm{M} \mathrm{KCl}(\mathrm{pH}=4)$ with $0.025 \mathrm{M} \mathrm{K}^{15} \mathrm{NO}_{3}$ and $0.025 \mathrm{M}$ $\mathrm{K}^{14} \mathrm{NO}_{2}$. CA was carried out with different applied charges. The $\mathrm{N}$-species in the resulting solution were quantified by HPLC (for ${ }^{15} \mathrm{NO}_{3}^{-}$), colorimetry (for total ${ }^{14} \mathrm{NO}_{2}{ }^{-}$and ${ }^{15} \mathrm{NO}_{2}^{-}$), and NMR $\left({ }^{14} \mathrm{NH}_{4}{ }^{+}\right.$and ${ }^{15} \mathrm{NH}_{4}{ }^{+}$), as detailed in Experimental Section.

We consider the following reactions in the electrolytic cell:

$$
\begin{array}{ll}
{ }^{15} \mathrm{NO}_{3}{ }^{-} \rightarrow{ }^{15} \mathrm{NO}_{2}{ }^{-} & k_{1} \\
{ }^{14} \mathrm{NO}_{2}{ }^{-} \rightarrow{ }^{14} \mathrm{NH}_{4}{ }^{+} & k_{2} \\
{ }^{15} \mathrm{NO}_{3}{ }^{-} \rightarrow{ }^{15} \mathrm{NH}_{4}{ }^{+} & k_{3} \\
{ }^{15} \mathrm{NO}_{2}{ }^{-} \rightarrow{ }^{15} \mathrm{NH}_{4}{ }^{+} & k_{4}
\end{array}
$$

All reactions were assumed to be first-order ${ }^{20-21}$ without isotopic effect $\left(k_{2}=k_{4}\right)$. In addition, 100\% ${ }^{15} \mathrm{~N}$ and ${ }^{14} \mathrm{~N}$ balances were assumed, in light of the $\sim 100 \%$ nitrogen balance for the electro-reduction of $\mathrm{NO}_{3}{ }^{-}$and $\mathrm{NO}_{2}{ }^{-}$, and the low selectivity towards $\mathrm{NO}_{2}, \mathrm{NO}, \mathrm{N}_{2} \mathrm{O}$, and $\mathrm{NH}_{2} \mathrm{OH}$ (Figure 2d and Table S3).

Let $\mathrm{A}={ }^{15} \mathrm{NO}_{3}{ }^{-}, \mathrm{B}={ }^{15} \mathrm{NO}_{2}^{-}, \mathrm{C}={ }^{15} \mathrm{NH}_{4}{ }^{+}, \mathrm{b}={ }^{14} \mathrm{NO}_{2}^{-}$, and $\mathrm{c}={ }^{14} \mathrm{NH}_{4}{ }^{+}$. The following 5 equations can be obtained by rate law:

$$
\begin{gathered}
\frac{\mathrm{d}[\mathrm{A}]}{\mathrm{d} t}=-k_{1}[\mathrm{~A}]-k_{3}[\mathrm{~A}] \\
\frac{\mathrm{d}[\mathrm{B}]}{\mathrm{d} t}=k_{1}[\mathrm{~A}]-k_{2}[\mathrm{~B}] \\
\frac{\mathrm{d}[\mathrm{C}]}{\mathrm{d} t}=k_{3}[\mathrm{~A}]+k_{2}[\mathrm{~B}] \\
\frac{\mathrm{d}[\mathrm{b}]}{\mathrm{d} t}=-k_{2}[\mathrm{~b}] \\
\frac{\mathrm{d}[\mathrm{c}]}{\mathrm{d} t}=k_{2}[\mathrm{~b}]
\end{gathered}
$$

By using the boundary conditions $\left([\mathrm{X}]=[\mathrm{X}]_{0}\right.$ for all species at $\left.t=0\right)$ and $\mathrm{N}$ balance $([\mathrm{A}]+[\mathrm{B}]+[\mathrm{C}]=$ $\left.[\mathrm{A}]_{0}+[\mathrm{B}]_{0}+[\mathrm{C}]_{0}\right)$, the solutions for $[\mathrm{A}],[\mathrm{b}]$, and $[\mathrm{B}]$ are:

$$
\begin{gathered}
{[\mathrm{A}]=[\mathrm{A}]_{0} \mathrm{e}^{-\left(k_{1}+k_{3}\right) t}} \\
{[\mathrm{~b}]=[\mathrm{b}]_{0} \mathrm{e}^{-k_{2} t}} \\
{[\mathrm{~B}]=\frac{k_{1}[\mathrm{~A}]_{0}}{k_{2}-k_{1}-k_{3}}\left[\mathrm{e}^{-\left(k_{1}+k_{3}\right) t}-\mathrm{e}^{-k_{2} t}\right]=\mathrm{f}(t) k_{1}}
\end{gathered}
$$

Therefore, $k_{2}$ and $\left(k_{1}+k_{3}\right)$ were calculated by linear regression of $\ln \left([\mathrm{b}] /[\mathrm{b}]_{0}\right)$ and $\ln \left([\mathrm{A}] /[\mathrm{A}]_{0}\right)$ on $t ; k_{1}$ was calculated by linear regression of $[\mathrm{B}]$ on $\mathrm{f}(t)=\frac{[\mathrm{A}]_{0}}{k_{2}-k_{1}-k_{3}}\left[\mathrm{e}^{-\left(k_{1}+k_{3}\right) t}-\mathrm{e}^{-k_{2} t}\right]$. The fitted curves and calculated rate constants are summarized in Figure S21. 
(a)

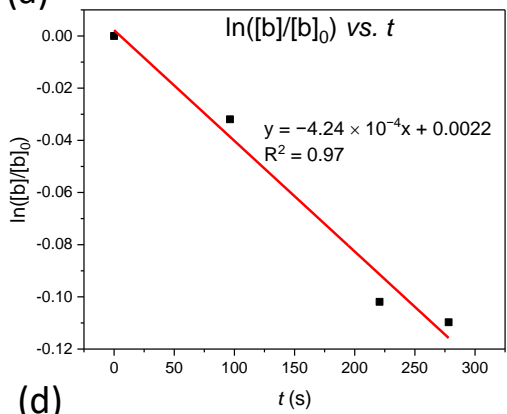

(d)

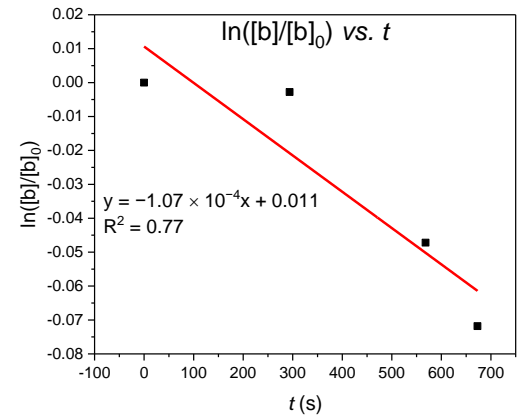

(b)

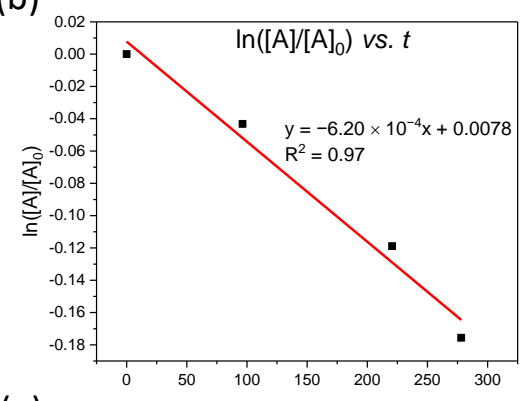

(e)

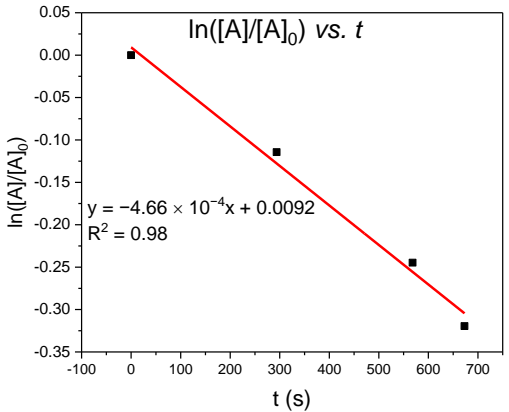

(c)

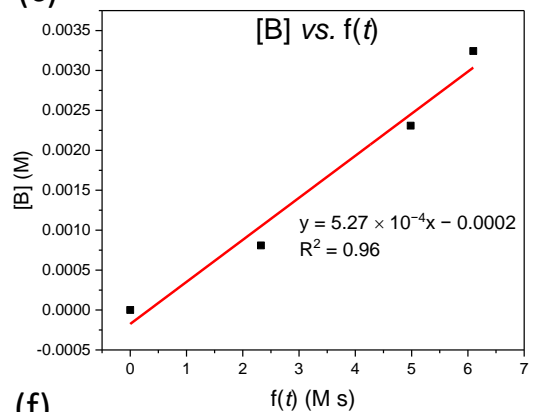

(f)

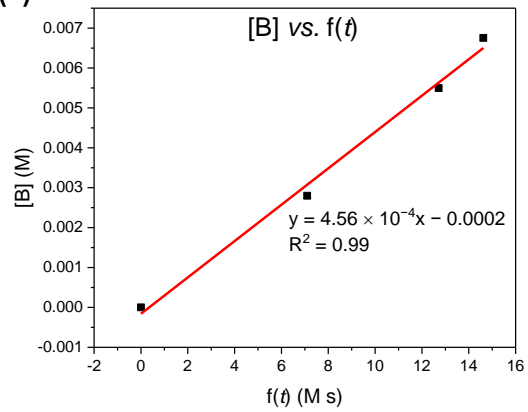

(g)

\begin{tabular}{ccccccc}
\hline $\begin{array}{c}\text { Potential }(\mathrm{V} \\
\text { vs. } \mathrm{Ag} / \mathrm{AgCl})\end{array}$ & $k_{1}\left(\mathrm{~min}^{-1}\right)$ & $k_{2}\left(\mathrm{~min}^{-1}\right)$ & $k_{3}\left(\mathrm{~min}^{-1}\right)$ & $\mathrm{R}^{2}$ for $k_{2}$ & $\mathrm{R}^{2}$ for $\left(k_{1}+k_{3}\right)$ & $\mathrm{R}^{2}$ for $k_{1}$ \\
\hline-1.50 & 0.0316 & 0.0255 & 0.0056 & 0.97 & 0.97 & 0.96 \\
-1.30 & 0.0273 & 0.00643 & 0.0007 & 0.77 & 0.98 & 0.99 \\
\hline
\end{tabular}

Figure S21. Electrolysis with $0.025 \mathrm{M}^{15} \mathrm{NO}_{3}{ }^{-}$and $0.025 \mathrm{M}^{14} \mathrm{NO}_{2}{ }^{-}$. The electrolyte was $0.1 \mathrm{M} \mathrm{KCl}(\mathrm{pH}$ $=4$ ) and the geometric area of OD-Ag was $2 \mathrm{~cm}^{2}$. (a)-(c) Electrolysis at $-1.50 \mathrm{~V}_{\mathrm{Ag} / \mathrm{AgCl}}$. (d)-(f) Electrolysis at $-1.30 \mathrm{~V}_{\mathrm{Ag} / \mathrm{AgCl}}$. (g) Summary of linear regression results. 
(a)

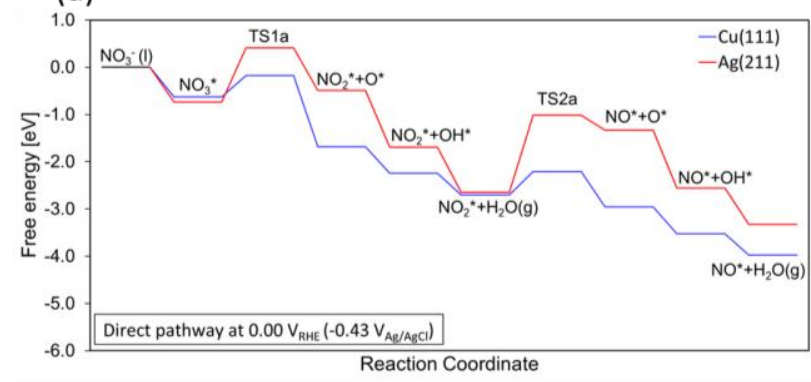

(c)

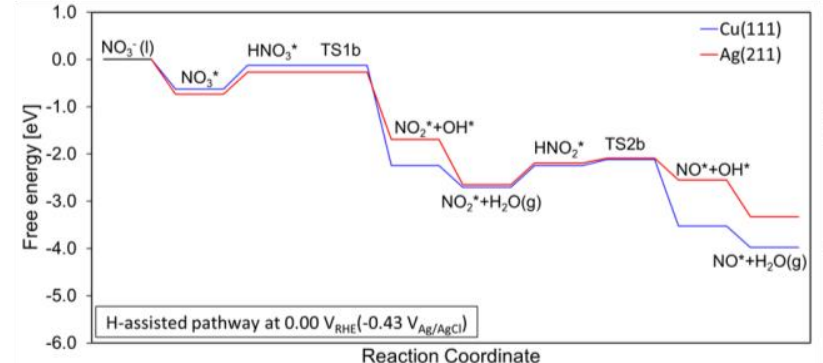

(b)

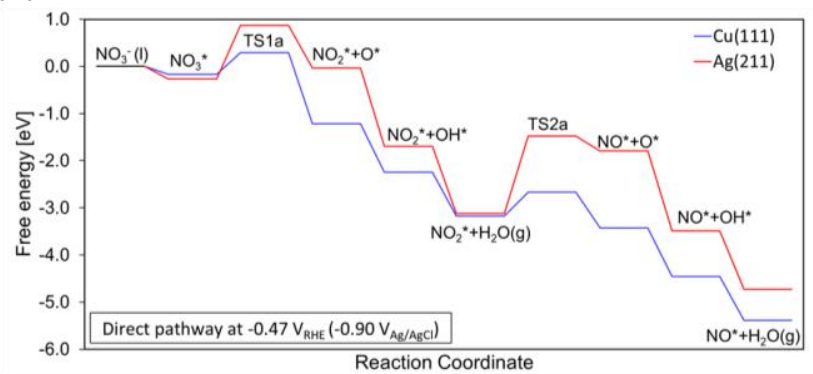

(d)

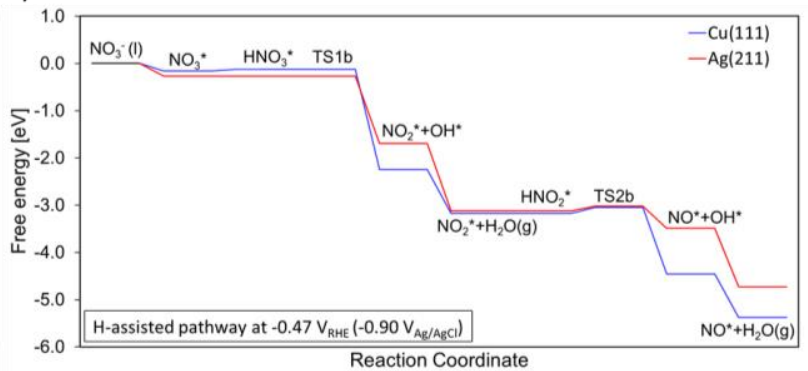

Figure S22. Energy diagrams of the considered reaction pathways of $\mathrm{NO}_{3}{ }^{-}$reduction on the two considered surfaces. The direct pathway at (a) $0.00 \mathrm{~V}_{\mathrm{RHE}}$ and (b) $-0.47 \mathrm{~V}_{\mathrm{RHE}}(-0.90 \mathrm{~V} \mathrm{Ag} / \mathrm{AgCl})$. The hydrogen assisted pathway at (c) $0.00 \mathrm{~V}_{\mathrm{RHE}}$ and (d) $-0.47 \mathrm{~V}_{\mathrm{RHE}}\left(-0.90 \mathrm{~V}_{\mathrm{Ag} / \mathrm{AgCl}}\right)$. 

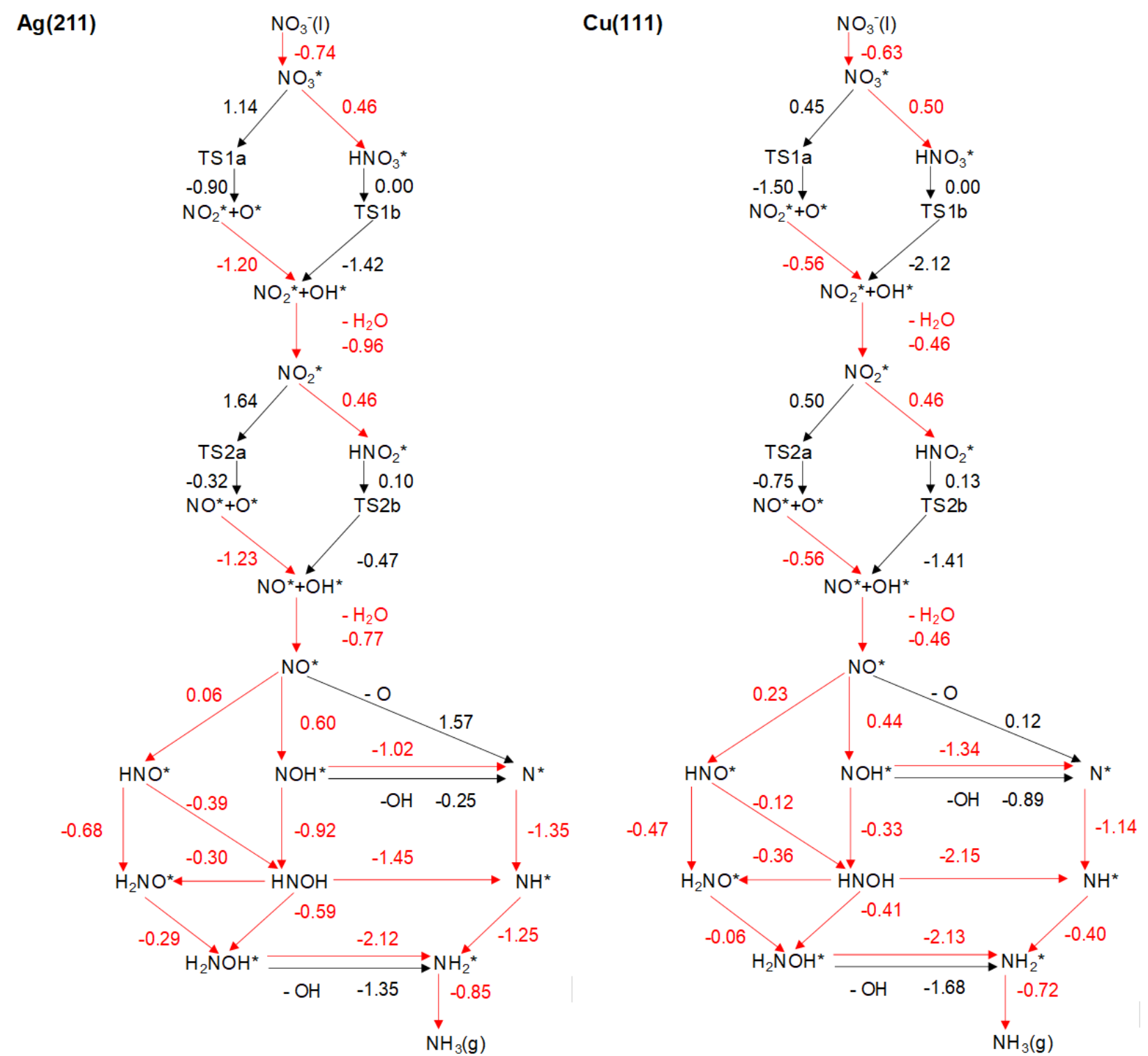

Figure S23. Reaction pathways of reduction of $\mathrm{NO}_{3}^{-}(\mathrm{l})$ to $\mathrm{NH}_{3}(\mathrm{~g})$ on $\mathrm{Ag}(211)$ and $\mathrm{Cu}(111)$ at 0.00 $V_{\text {RHE }}\left(-\mathbf{0 . 4 3} \mathrm{V}_{\mathrm{Ag} / \mathrm{AgCl}}\right)$. All numbers represent the DFT-calculated change in free energy (eV) at the given potential. Red arrows denote electrochemical steps (with proton-electron transfer, potential dependent); black arrows denote non-electrochemical steps (potential independent). 

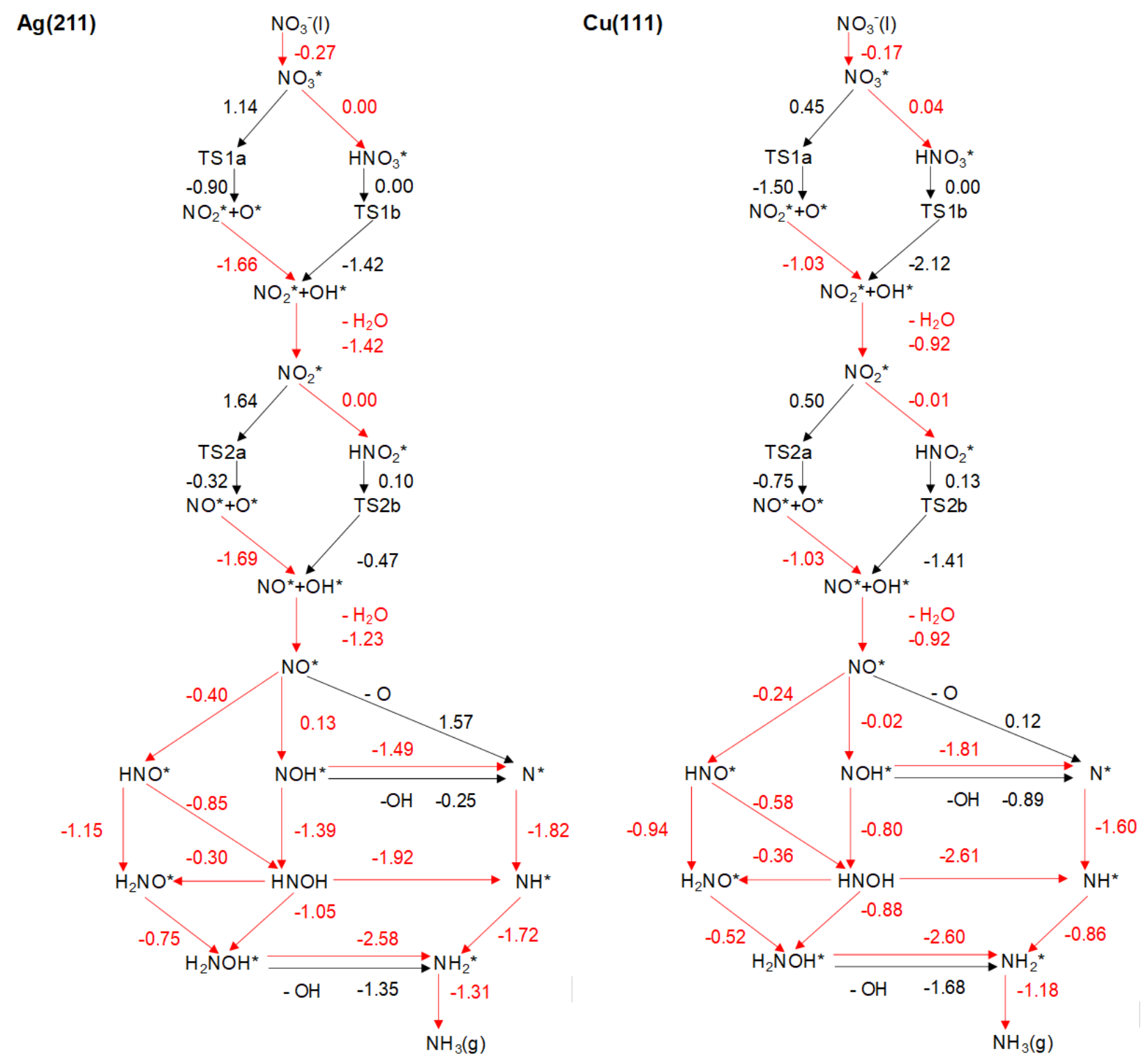

Figure S24. Reaction pathways of reduction of $\mathrm{NO}_{3}^{-}(\mathrm{l})$ to $\mathrm{NH}_{3}(\mathrm{~g})$ on $\mathrm{Ag}(211)$ and $\mathrm{Cu}(111)$ at -0.47 $\mathrm{V}_{\mathbf{R H E}}\left(-\mathbf{0 . 9 0} \mathrm{V}_{\mathrm{Ag} / \mathrm{AgCl}}\right)$. All numbers represent the DFT-calculated change in free energy $(\mathrm{eV})$ at the given potential. Red arrows denote electrochemical steps (with proton-electron transfer, potential dependent); black arrows denote non-electrochemical steps (potential independent). 


\section{Supplementary Note 2. Potential dependent activation energy of electrochemical steps}

As discussed in recent work, ${ }^{22}$ the potential dependent activation barrier $\left(\mathrm{E}_{\mathrm{act}}\right)$ for an electrochemical step $\left(X^{*}+H_{a q}^{+}+e^{-} \rightarrow X H^{*}\right)$ can be approximated as follows using DFT:

$$
\begin{gathered}
\mathrm{U}^{0}=\frac{-\mathrm{G}_{(\mathrm{X}+\mathrm{H})^{*}}+\mathrm{G}_{\mathrm{X}^{*}}+\frac{1}{2} \mathrm{G}_{\mathrm{H}_{2}(\mathrm{~g})}}{\mathrm{e}^{-}} \\
\mathrm{E}_{\mathrm{act}}=\mathrm{E}_{\mathrm{act}}^{0}\left(\mathrm{U}^{0}\right)+\mathrm{e} \beta\left(\mathrm{U}-\mathrm{U}^{0}\right)
\end{gathered}
$$

where $\beta$ is the reaction symmetry factor, $\mathrm{E}_{\mathrm{act}}^{0}\left(\mathrm{U}^{0}\right)$ is the activation energy of the non-electrochemical reduction reaction, and $\mathrm{U}$ is the applied potential.

As an example in our work, we applied this to the formation of $\mathrm{HNO}_{3} *$ on $\mathrm{Cu}(111)$ :

$$
\begin{aligned}
& \mathrm{U}^{0}=\frac{-\mathrm{G}_{\left(\mathrm{H}+\mathrm{NO}_{3}\right)^{*}}+\mathrm{G}_{\mathrm{NO}_{3}^{*}}+\frac{1}{2} \mathrm{G}_{\mathrm{H}_{2}(\mathrm{~g})}}{\mathrm{e}^{-}}=-0.03 \mathrm{~V} \text { vs. RHE } \\
& \mathrm{e} \beta\left(\mathrm{U}-\mathrm{U}^{0}\right)=\mathrm{e} \times 0.5(-0.47 \mathrm{~V}+0.03 \mathrm{~V})=-0.22 \mathrm{eV}
\end{aligned}
$$

We also applied this to the same reaction step on $\operatorname{Ag}(211)$ :

$$
\begin{gathered}
\mathrm{U}^{0}=\frac{-\mathrm{G}_{\left(\mathrm{H}+\mathrm{NO}_{3}\right)^{*}}+\mathrm{G}_{\mathrm{NO}_{3}^{*}}+\frac{1}{2} \mathrm{G}_{\mathrm{H}_{2}(\mathrm{~g})}}{\mathrm{e}^{-}}=-0.38 \mathrm{eV} \text { vs. RHE } \\
\mathrm{e} \beta\left(\mathrm{U}-\mathrm{U}^{0}\right)=\mathrm{e} \times 0.5(-0.47 \mathrm{~V}+0.38 \mathrm{~V})=-0.05 \mathrm{eV}
\end{gathered}
$$

In the above calculation, $\beta$ was assumed to be 0.5 , as done in previous work. ${ }^{23}$ When $U$ was $-0.47 V_{\text {RHE, }}$ equivalent to $-0.90 \mathrm{~V}_{\mathrm{Ag} / \mathrm{AgCl}}$ at which we present energetics in Figure 4 of the main text, the activation barrier could decrease by $0.21 \mathrm{eV}$ and $0.05 \mathrm{eV}$ on $\mathrm{Cu}(111)$ and $\mathrm{Ag}(211)$, respectively, due to the applied potential. We do not calculate explicit values of $E_{\text {act }}^{0}\left(U^{0}\right)$ for these reaction steps in this work, though note that previous work has shown, e.g., water-mediated proton transfers to have small barriers of $0.15 \mathrm{eV}$ or less. ${ }^{22}$ We also note that a previous DFT study ${ }^{24}$ reported the formation of $\mathrm{HNO}_{3}$ from $\mathrm{NO}_{3}$ and $\mathrm{H}$ is exothermic with no barrier in the gas phase. Although the linearity assumption in this formulation may break down at highly negative potentials (i.e., the calculated reduction in barrier for $\mathrm{Cu}(111)$ might actually exceed the barrier itself), we nonetheless anticipate that the substantial reduction in activation energy will render the corresponding steps effectively barrierless (regardless of the actual calculated reduction) at such negative potentials. We therefore on this basis justify our assumption that these barriers are governed essentially by the free energy change of the corresponding reactions at the potentials relevant to this study $\left(-0.90 \mathrm{~V}_{\mathrm{Ag} / \mathrm{AgCl}}\right.$ and more reducing values). 


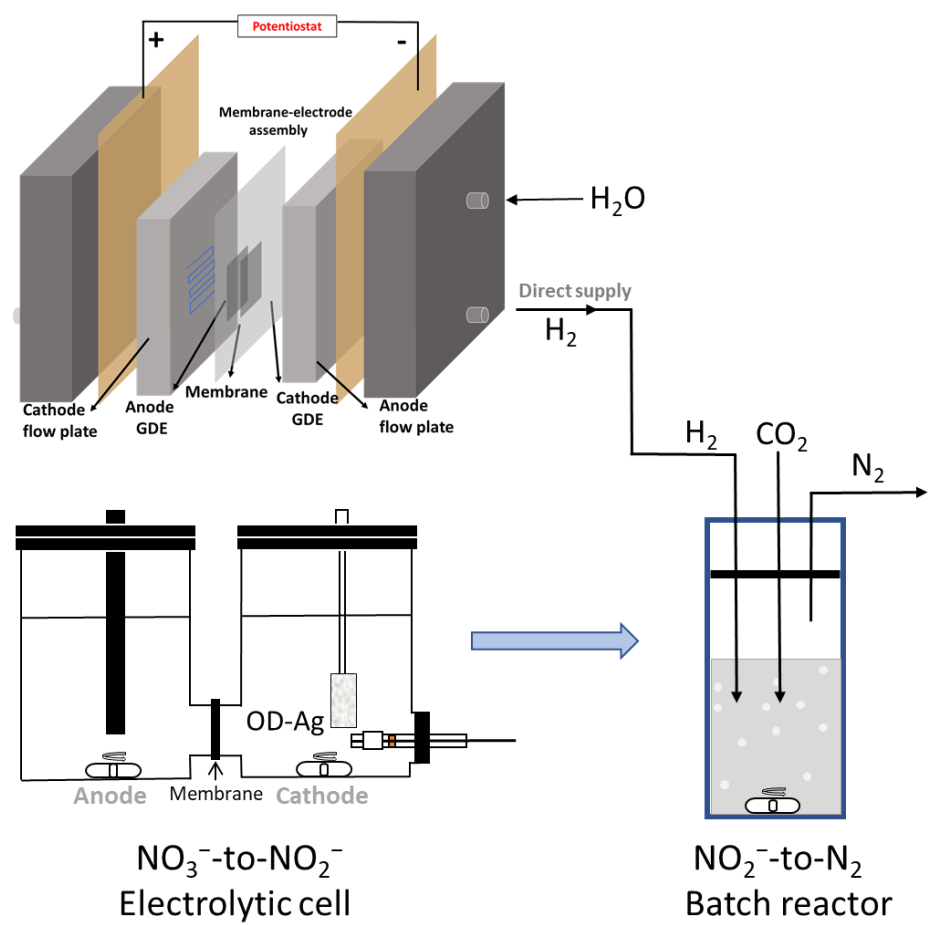

Figure S25. The experimental set-up of the electrocatalytic-catalytic combined process, and $\mathrm{H}_{2}$ feed was generated from a PEM water electrolyzer.

(a)

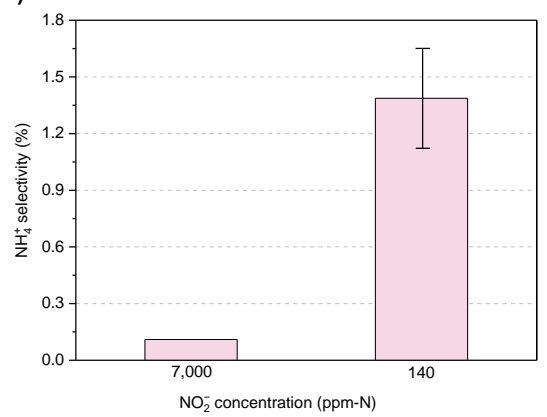

(b)

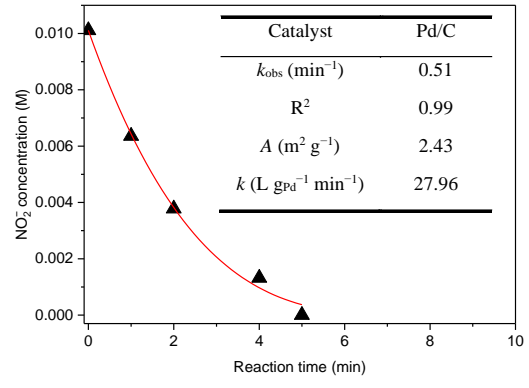

(c)

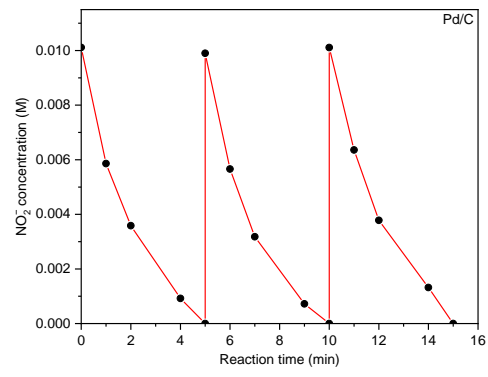

Figure S26. Catalytic reduction of $\mathrm{NO}_{2}^{-}$on $\mathbf{P d} / \mathbf{C}$. The reaction medium was $0.1 \mathrm{M} \mathrm{KCl}$ with $0.1 \mathrm{M} \mathrm{KOH}$ saturated by $\mathrm{CO}_{2}$. The catalyst loading was $50 \mathrm{mg}$. (a) Selectivity of $\mathrm{NH}_{4}{ }^{+}$after full conversion of 7,000 and $140 \mathrm{ppm}$ of $\mathrm{NO}_{2}{ }^{-} \mathrm{N}$. The error bar represents the standard deviation of three independent measurements. (b) $\mathrm{NO}_{2}^{-}$concentration profile during its catalytic reduction. The fitted curve assumes pseudo-first-order dependence on $\mathrm{NO}_{2}{ }^{-}$concentration. The observed rate constant $\left(k_{\mathrm{obs}}\right)$, the active surface area of $\mathrm{Pd}(A)$, and surface Pd-normalized rate constant $(k)$ are shown in the inset table. (c) $\mathrm{NO}_{2}{ }^{-}$concentration profile for three consecutive measurements. 
(a)
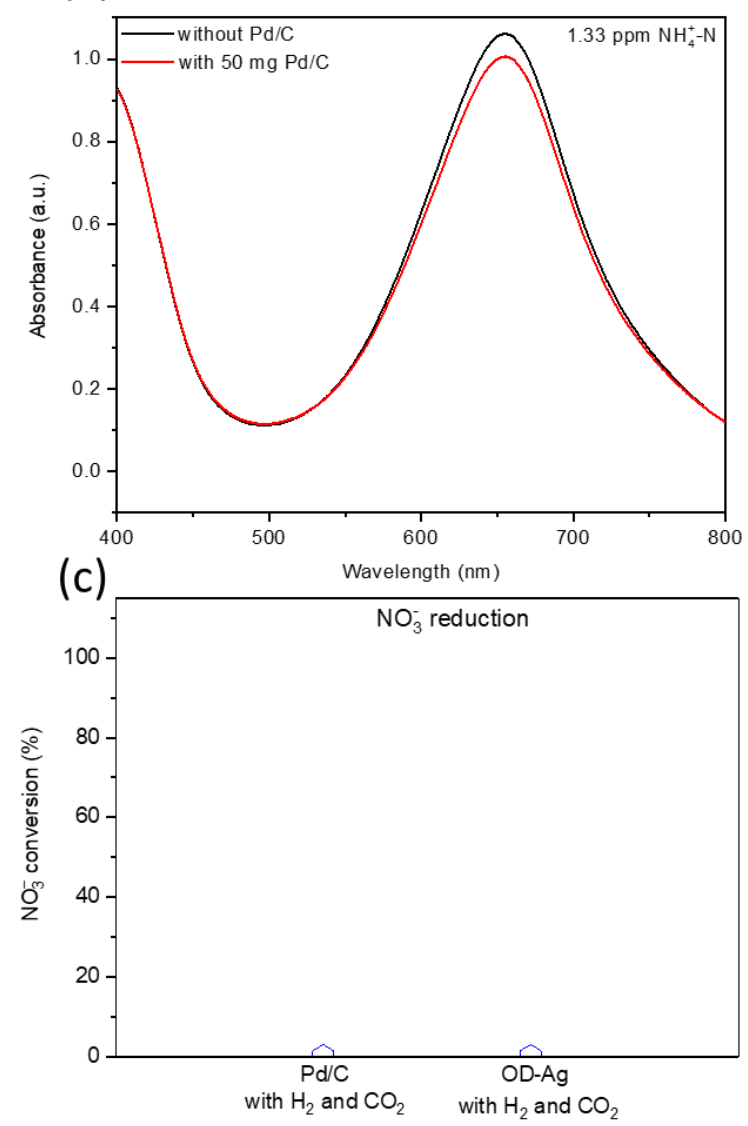

(b)

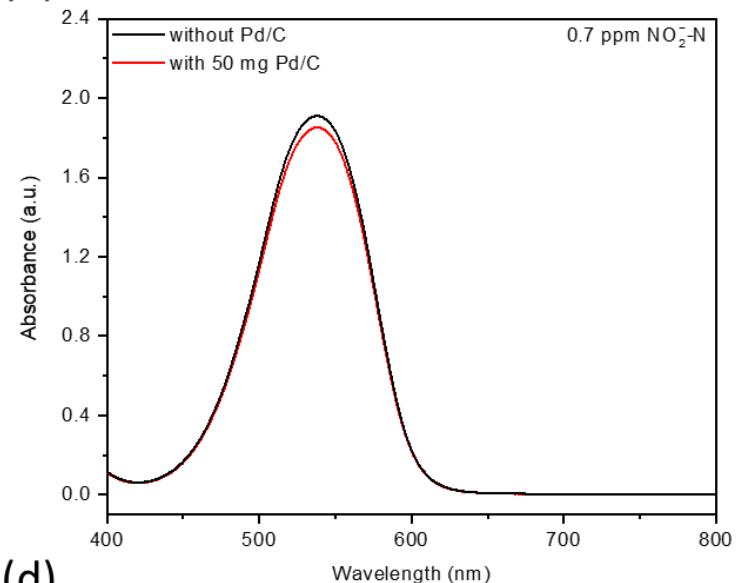

(d)

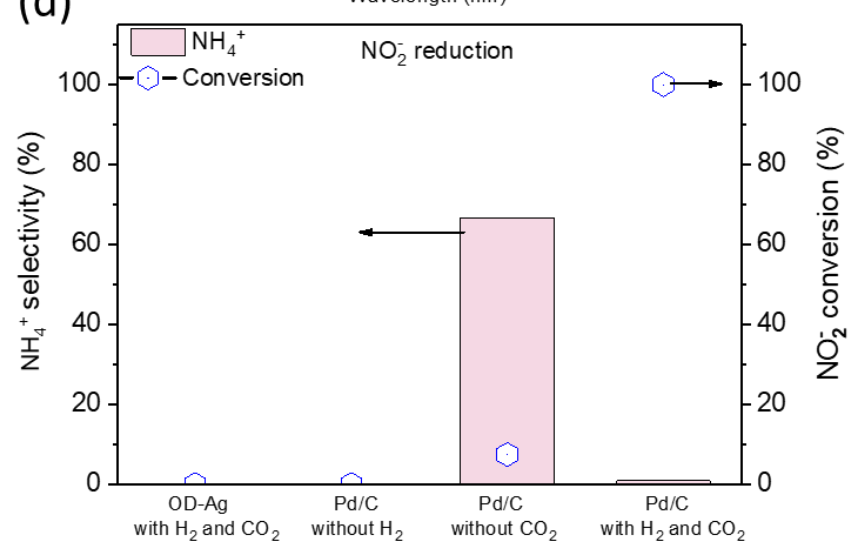

Figure S27. Control experiments for catalytic reduction of $\mathrm{NO}_{3}{ }^{-}$and $\mathrm{NO}_{2}{ }^{-}$. The conditions for control experiments (a)-(b) were the same as catalytic reduction tests, except that no $\mathrm{H}_{2}$ was fed. (a) UV-Vis spectra for $1.33 \mathrm{ppm}$ of $\mathrm{NH}_{4}{ }^{+}-\mathrm{N}$ in $\mathrm{CO}_{2}$-saturated electrolyte stained with indophenol blue indicator, with or without adding $50 \mathrm{mg}$ of $\mathrm{Pd} / \mathrm{C}$. (b) $\mathrm{UV}$-Vis spectra for $0.7 \mathrm{ppm}$ of $\mathrm{NO}_{2}{ }^{-} \mathrm{N}$ in $\mathrm{CO}_{2}$-saturated electrolyte stained with Griess reagent, with or without adding $50 \mathrm{mg}$ of $\mathrm{Pd} / \mathrm{C}$. The adsorption of $\mathrm{NH}_{4}{ }^{+}$and $\mathrm{NO}_{2}{ }^{-}$contributed to a decrease of $5.2 \%$ and $3.0 \%$ in the measured concentrations, respectively.

(c) Conversion for catalytic reduction of $0.01 \mathrm{M} \mathrm{NO}_{3}{ }^{-}$by $\mathrm{H}_{2}$ in $\mathrm{CO}_{2}$-saturated $0.1 \mathrm{M} \mathrm{KCl}$ and $0.1 \mathrm{M} \mathrm{KOH}$

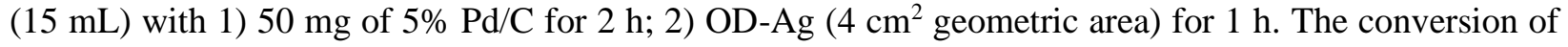
$\mathrm{NO}_{3}{ }^{-}$was very low $(<1 \%)$ for both cases.

(d) Conversion and $\mathrm{NH}_{4}{ }^{+}$selectivity for catalytic reduction of $0.01 \mathrm{M} \mathrm{NO}_{2}{ }^{-}$in $\mathrm{CO}_{2}$-saturated $0.1 \mathrm{M} \mathrm{KCl}$ and $0.1 \mathrm{M} \mathrm{KOH}(15 \mathrm{~mL})$ with 1) $\mathrm{OD}-\mathrm{Ag}$ with both $\mathrm{H}_{2}$ and $\mathrm{CO}_{2}$ flow for $\left.1 \mathrm{~h} ; 2\right) 50 \mathrm{mg}$ of $5 \% \mathrm{Pd} / \mathrm{C}$ and no $\mathrm{H}_{2}$ flow for $1 \mathrm{~h}$; 3) $100 \mathrm{mg}$ of $5 \% \mathrm{Pd} / \mathrm{C}$ and no $\mathrm{CO}_{2}$ flow for $0.5 \mathrm{~h}$; 4) $50 \mathrm{mg}$ of $5 \% \mathrm{Pd} / \mathrm{C}$ with both $\mathrm{H}_{2}$ and $\mathrm{CO}_{2}$ flow for $25 \mathrm{~min}$. The conversion of $\mathrm{NO}_{2}{ }^{-}$was negligible $(<1 \%)$ on OD-Ag and $\mathrm{Pd} / \mathrm{C}$ without $\mathrm{H}_{2}$ feed. Without the buffering effect of $\mathrm{CO}_{2}$, the $\mathrm{pH}$ of the electrolyte increased significantly as the reaction proceeded $\left(2 \mathrm{NO}_{2}{ }^{-}+3 \mathrm{H}_{2} \rightarrow \mathrm{N}_{2}+2 \mathrm{OH}^{-}+2 \mathrm{H}_{2} \mathrm{O}\right)$. At higher $\mathrm{pH}$, the reaction rate was suppressed, and the production of $\mathrm{NH}_{4}{ }^{+}$became more favorable, which is in accordance with ref. ${ }^{1}$ 


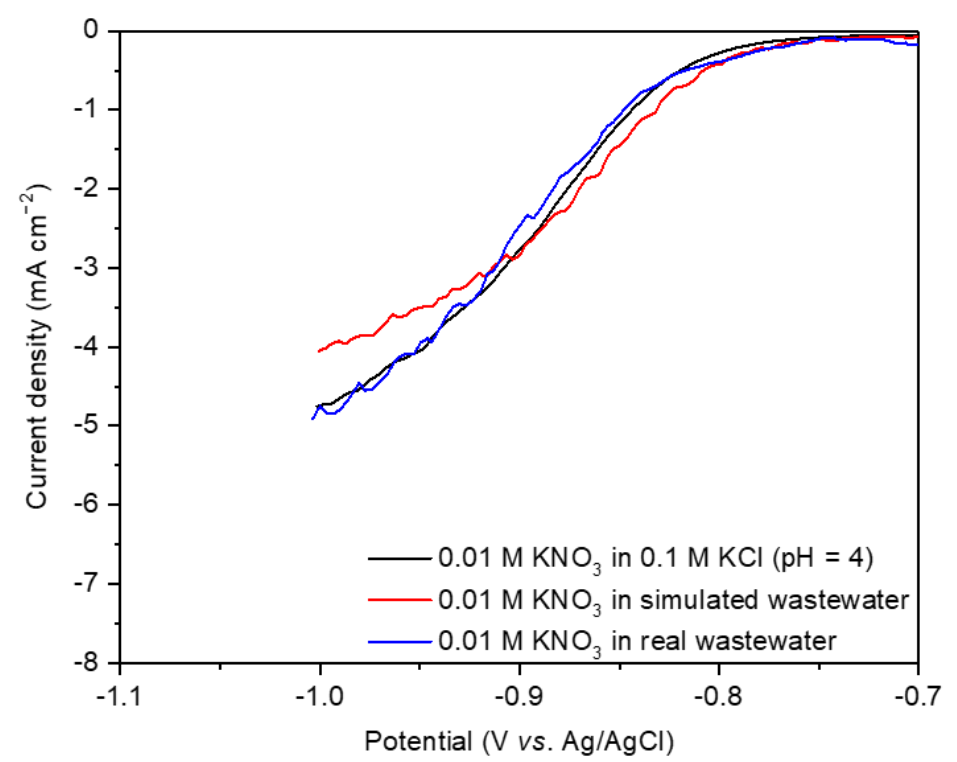

Figure S28. Linear sweep voltammograms of NO3RR in different reaction media. The electrolytes contain $0.01 \mathrm{M} \mathrm{NO}_{3}^{-}(140 \mathrm{ppm}-\mathrm{N})$, and the geometric area of OD-Ag was $6 \mathrm{~cm}^{2}$. 
(a)

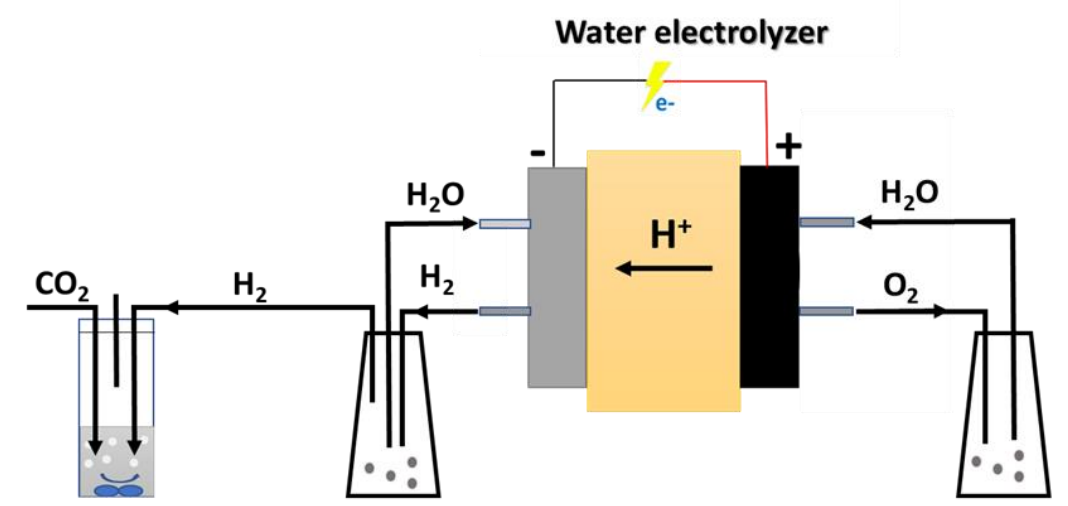

(b)
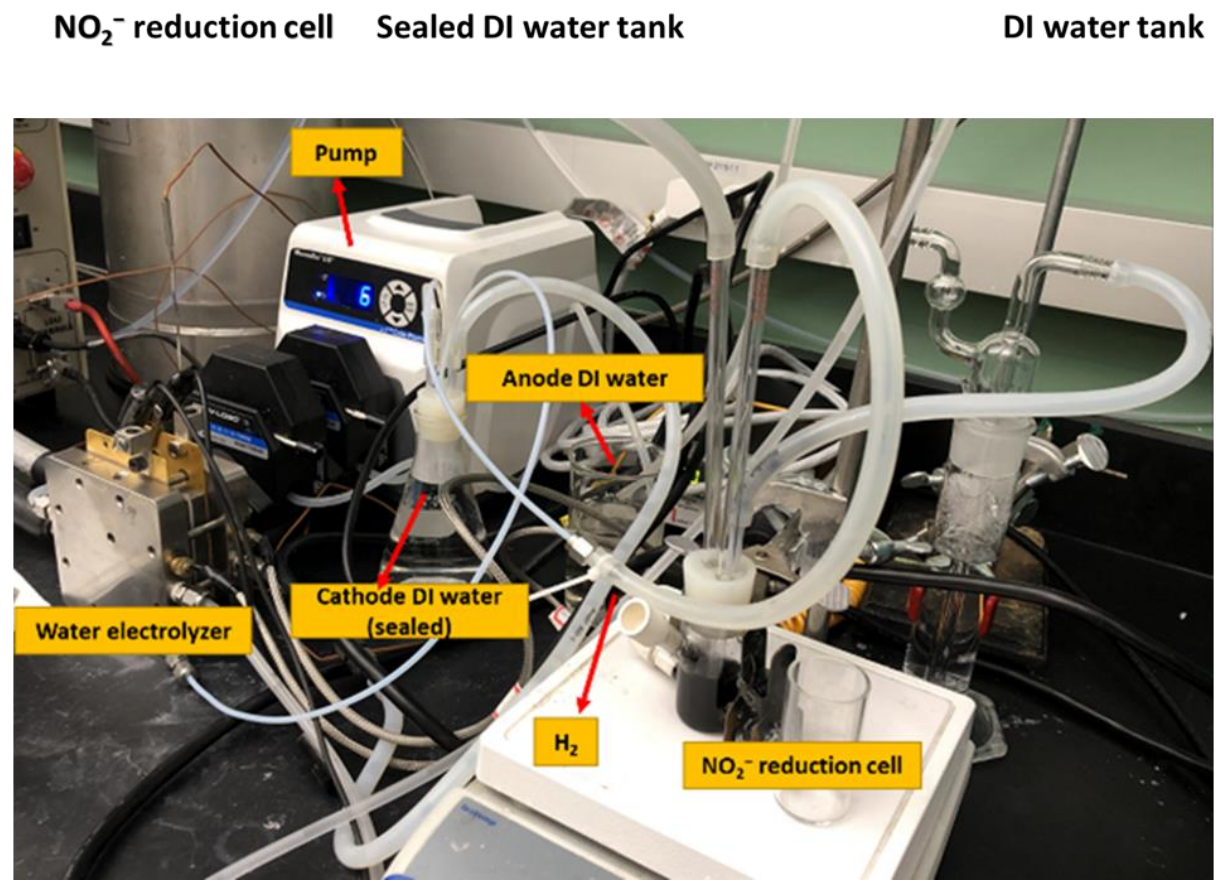

Figure S29. Catalytic reduction of $\mathrm{NO}_{2}^{-}$by water-splitting-derived $\mathrm{H}_{2}$. (a) Schematic illustration and (b) Photograph of the experimental setup. The detailed PEM water electrolyzer set-up was described in the Methods section in the main text. The catalytic reduction conditions were described in the Methods section in the main text, except that $\mathrm{H}_{2}$ feed was generated from a PEM water electrolyzer. $\mathrm{NO}_{2}{ }^{-}$was completely removed within 15 min with $0.9 \%$ selectivity to $\mathrm{NH}_{4}{ }^{+}$, showing no significant difference with the performance with UHP $\mathrm{H}_{2}$ feed (Figure S26). 
Supplementary Note 3. pH effect study for NO3RR on OD-Ag (Figure S30-32).

(a)

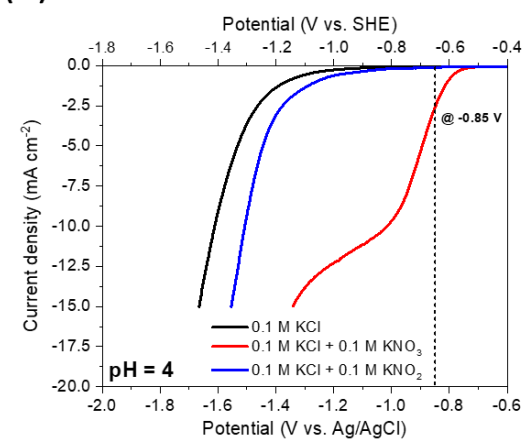

(d)

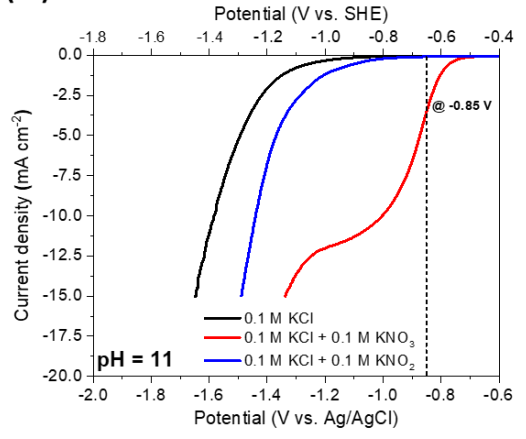

(b)

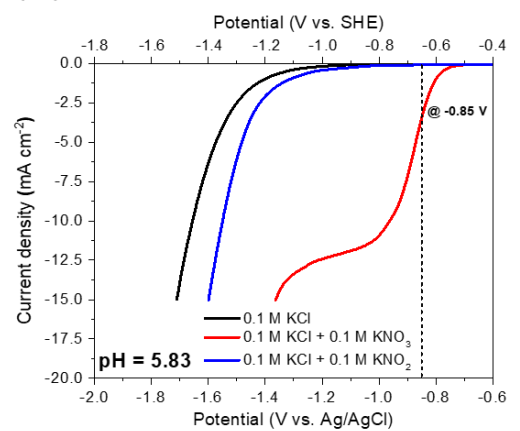

(e)

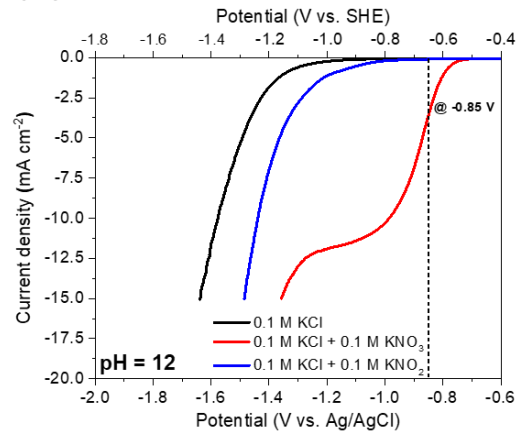

(c)

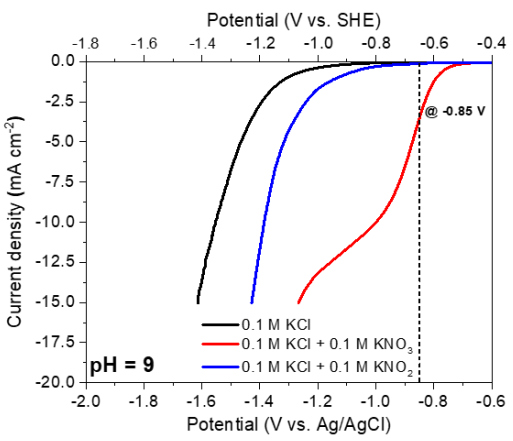

(f)

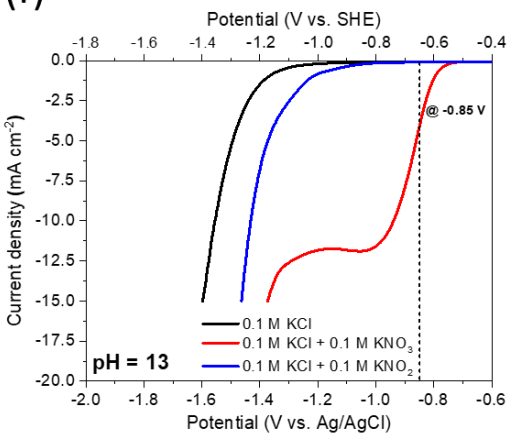

Figure S30. pH effect study for NO3RR on OD-Ag $\left(4 \mathbf{~ c m}^{2}\right.$ geometric area). (a)-(f) Linear sweep voltammetry of OD-Ag in $0.1 \mathrm{M} \mathrm{KCl}, 0.1 \mathrm{M} \mathrm{KCl}$ with $0.1 \mathrm{M} \mathrm{NO}_{3}{ }^{-}$, and $0.1 \mathrm{M} \mathrm{KCl}$ with $0.1 \mathrm{M} \mathrm{NO}_{2}{ }^{-}$at $\mathrm{pH}$ 4-13. The current density labeled inside the figures was the data used for the E-pH diagram calculation. The $\mathrm{pH}$ of the electrolyte was adjusted by adding $\mathrm{HCl}$ or $\mathrm{KOH}$. The SHE scales of potential was calculated by $E(\mathrm{~V} v s . \mathrm{SHE})=E(\mathrm{~V} v s . \mathrm{Ag} / \mathrm{AgCl})+0.197 \mathrm{~V}$. 
(a)

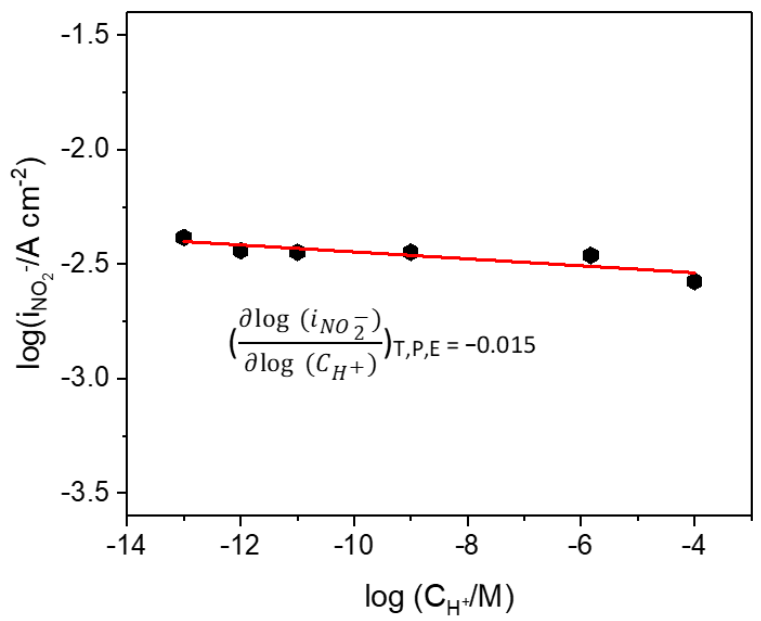

(b)

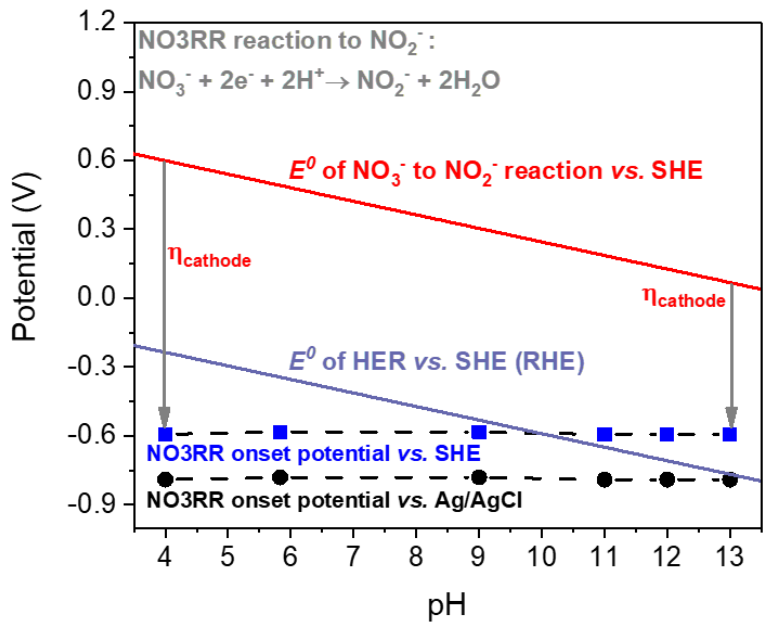

Figure S31. pH effect study for NO3RR on OD-Ag (4 cm ${ }^{2}$ geometric area). (a) $\mathrm{NO}_{3}{ }^{-}$order dependence fitting in $0.1 \mathrm{M} \mathrm{KCl}$ with different concentrations of $\mathrm{NO}_{3}{ }^{-}(\mathrm{pH}=4)$ at $-0.85 \mathrm{~V}_{\mathrm{Ag} / \mathrm{AgCl}}$ with data obtained from LSV curves in Figure S30. (b) E-pH diagram for the electroreduction of $\mathrm{NO}_{3}{ }^{-}$to $\mathrm{NO}_{2}{ }^{-}$.

$\mathrm{NO}_{3}{ }^{-}$-to- $\mathrm{NO}_{2}{ }^{-}$reaction: $\mathrm{NO}_{3}{ }^{-}+2 \mathrm{H}^{+}+2 \mathrm{e}^{-} \rightarrow \mathrm{NO}_{2}{ }^{-}+2 \mathrm{H}_{2} \mathrm{O}$

The observed NO3RR onset potentials in all investigated $\mathrm{pH}$ (Figure S30) showed similar values versus SHE but different versus RHE. In contrast, the thermodynamic potential $E^{0}$ for the reaction of $\mathrm{NO}_{3}{ }^{-}$-to$\mathrm{NO}_{2}{ }^{-}$is $\mathrm{pH}$-dependent, which is equal to $E^{0}\left(\mathrm{NO}_{3}{ }^{-} / \mathrm{NO}_{2}{ }^{-}\right)=0.835 \mathrm{~V}-0.059 \times \mathrm{pH}$. thus, resulting in a lower required overpotential in a higher $\mathrm{pH}$ electrolyte. Overpotential $\left(\eta_{\text {cathode }}\right)=$ Onset potential $-\mathrm{E}^{0}$ $\left(\mathrm{NO}_{3}{ }^{-} / \mathrm{NO}_{2}{ }^{-}\right)$. The conversion between SHE, RHE, and $\mathrm{Ag} / \mathrm{AgCl}$ was calculated by: $E$ (V vs. SHE) $=E(\mathrm{~V} v s . \mathrm{Ag} / \mathrm{AgCl})+0.197 \mathrm{~V} . E(\mathrm{~V} v s . \mathrm{RHE})=E(\mathrm{~V} v s . \mathrm{Ag} / \mathrm{AgCl})+0.059 \times \mathrm{pH}+0.197 \mathrm{~V} . \mathrm{RHE}$ is $\mathrm{pH}-$ dependent, plotted as the thermodynamic potential $E^{0}$ for HER: $\mathrm{V} v s$. SHE $=0-0.059 \times \mathrm{pH}$.

(a)

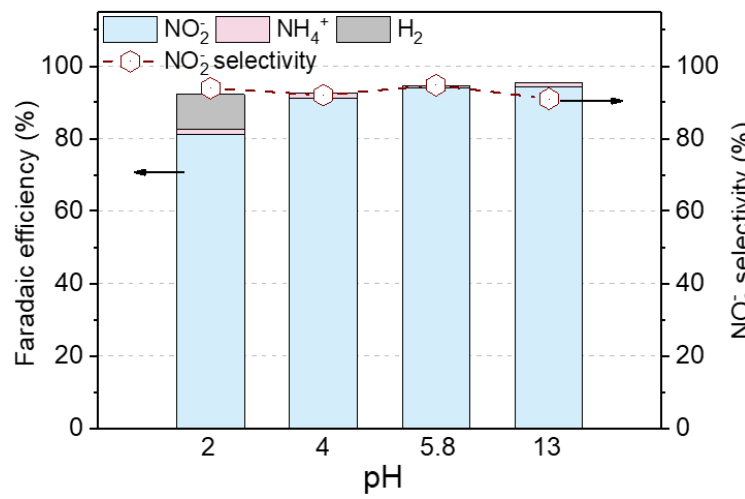

(b)

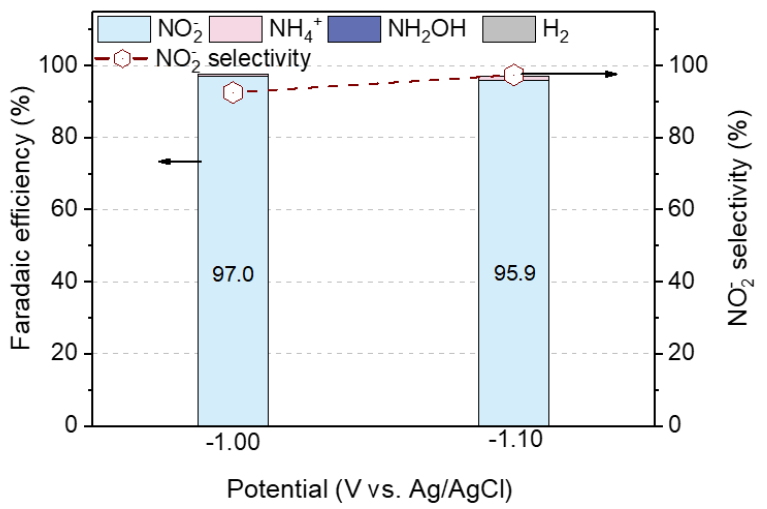

Figure S32. pH effect study for NO3RR on OD-Ag $\left(4 \mathrm{~cm}^{2}\right.$ geometric area). (a) FE of different products and $\mathrm{NO}_{2}{ }^{-}$selectivity at a constant current $\left(25 \mathrm{~mA}\right.$ ) for $1 \mathrm{~h}$. (b) $\mathrm{FE}$ of different products and $\mathrm{NO}_{2}{ }^{-}$selectivity at constant voltages $(-1.00 \mathrm{~V}$ and $-1.10 \mathrm{~V} v s . \mathrm{Ag} / \mathrm{AgCl})$ for $1 \mathrm{~h}$ at $\mathrm{pH} 13$. The constant current and constant potential tests were performed in $15 \mathrm{~mL}$ of $0.1 \mathrm{M} \mathrm{KCl}$ with $0.1 \mathrm{M} \mathrm{NO}_{3}{ }^{-}$at different $\mathrm{pH}$. The almost identical $\mathrm{NO}_{2}{ }^{-}$selectivity and $\mathrm{NO}_{2}{ }^{-}$faradaic efficiency at different $\mathrm{pH}$ suggested that the potential-controlled selectivity can be maintained in a broad range of $\mathrm{pH}$. 
(a)

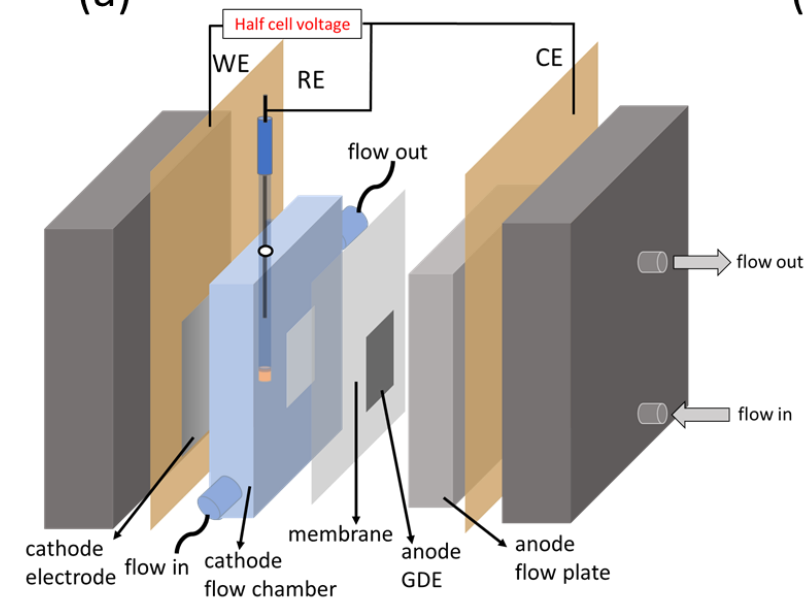

(b)

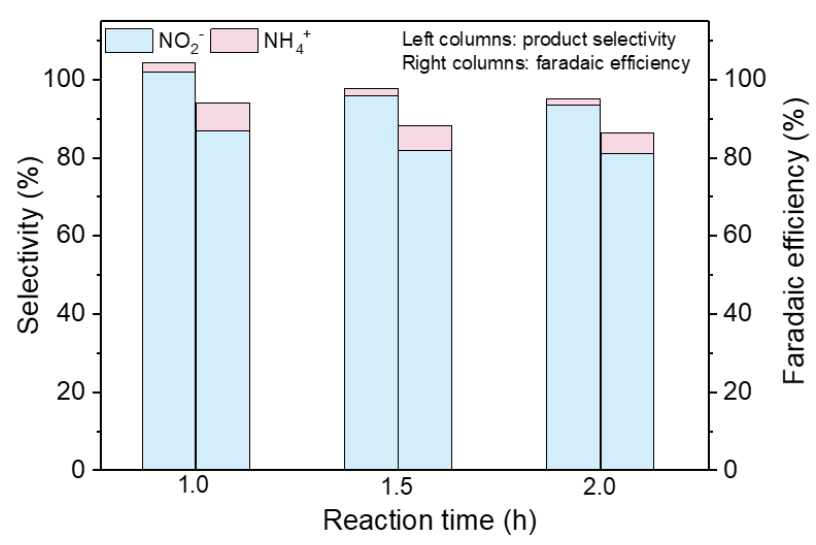

Figure S33. NO3RR in a three-electrode flow cell on OD-Ag $\left(4 \mathrm{~cm}^{2}\right.$ geometric area). (a) Scheme illustration of the three-electrode flow cell. (b) product selectivity and Faradaic efficiency at constant voltage of $-1.15 \mathrm{~V}_{\mathrm{Ag} / \mathrm{AgCl}}$ for different reaction time. The tests were performed in $15 \mathrm{~mL}$ of $0.1 \mathrm{M} \mathrm{KCl}(\mathrm{pH}$ =4) with $0.1 \mathrm{M} \mathrm{NO}_{3}{ }^{-}$. The three-electrode single electrolysis cell contained stainless-steel endplates, gold current collectors, a PTFE flow chamber (cathode) with a hole to insert $\mathrm{Ag} / \mathrm{AgCl}$ reference, an Nafion membrane $\left(\mathrm{K}^{+}\right.$form), and a flow-field graphite plate (anode). Peristaltic pumps (Masterflex ${ }^{\circledR} \mathrm{L} / \mathrm{S}^{\circledR}$ ) circulated catholyte and anolyte both of $25 \mathrm{ml} \mathrm{min}^{-1}$ inside $1 / 8$ silicon tubes (Masterflex). 


\section{Supplementary Tables (1-12)}

Table S1. Summary of onset potentials $\left(\mathrm{V}_{\mathrm{Ag} / \mathrm{AgCl}}\right.$, defined as the potential in which the current density attained $-0.75 \mathrm{~mA} \mathrm{~cm}$ ) and onset potential difference on different electrodes. The linear sweep voltammograms are shown in Figure S1 and Figure 1b-c.

\begin{tabular}{|c|c|c|c|c|c|}
\hline Electrode & $E_{\mathrm{NO} 3 \mathrm{RR}}\left(\mathrm{V}_{\mathrm{Ag} / \mathrm{AgCl}}\right)$ & $E_{\mathrm{NO} 2 \mathrm{RR}}\left(\mathrm{V}_{\mathrm{Ag} / \mathrm{AgCl}}\right)$ & $E_{\mathrm{HER}}\left(\mathrm{V}_{\mathrm{Ag} / \mathrm{AgCl}}\right)$ & $\begin{array}{c}E_{\mathrm{NO} 3 \mathrm{RR}}-E_{\mathrm{NO} 2 \mathrm{RR}} \\
(\mathrm{mV})\end{array}$ & $E_{\mathrm{NO}} 3 \mathrm{RR}-E_{\mathrm{HER}}(\mathrm{mV}$ \\
\hline $\mathrm{Ti}$ & -1.37 & -1.21 & -1.51 & -160 & 140 \\
\hline $\mathrm{Pt}$ & -0.91 & -0.76 & -0.90 & -150 & -10 \\
\hline $\mathrm{Zr}$ & -1.56 & -1.41 & -1.65 & -150 & 90 \\
\hline $\mathrm{Fe}$ & -1.08 & -0.94 & -1.14 & -140 & 60 \\
\hline $\mathrm{Ni}$ & -0.95 & -0.81 & -1.11 & -140 & 160 \\
\hline $\mathrm{Pd}$ & -1.07 & -1.00 & -1.10 & -70 & 30 \\
\hline $\mathrm{Au}$ & -1.26 & -1.21 & -1.33 & -50 & 70 \\
\hline V & -1.30 & -1.25 & -1.40 & -50 & 100 \\
\hline Mo & -1.23 & -1.19 & -1.21 & -40 & -20 \\
\hline $\mathrm{Bi}$ & -1.42 & -1.38 & -1.52 & -40 & 100 \\
\hline Co & -0.84 & -0.80 & -1.21 & -40 & 370 \\
\hline $\mathrm{Zn}$ & -1.33 & -1.30 & -1.61 & -30 & 280 \\
\hline Sn & -1.68 & -1.66 & -1.64 & -20 & -40 \\
\hline $\mathrm{Al}$ & -1.98 & -1.96 & -1.91 & -20 & -70 \\
\hline $\mathrm{W}$ & -1.24 & -1.23 & -1.27 & -10 & 30 \\
\hline $\mathrm{Pb}$ & -1.60 & -1.60 & -1.71 & 0 & 110 \\
\hline $\mathrm{Cu}$ & -0.94 & -0.99 & -1.35 & 50 & 410 \\
\hline $\mathrm{Ag}$ & -1.00 & -1.41 & -1.53 & 410 & 530 \\
\hline
\end{tabular}


Table S2. Summary of state-of-the-art NO3RR electrocatalysts for $\mathrm{NH}_{3}$ production. "N/A" indicates the parameter is not available in the publication.

\begin{tabular}{|c|c|c|c|c|}
\hline $\mathrm{NO}_{3}{ }^{-}$concentration $(\mathrm{ppm}-\mathrm{N})$ & Catalyst & $\mathrm{NO}_{3}{ }^{-}$conversion $(\%)$ & $\mathrm{FE}$ of $\mathrm{NH}_{3}(\%)$ & Ref. \\
\hline 500 & O-Cu-PTCDA & N/A & 85.9 & 25 \\
\hline 200 & $\mathrm{Cu} / \mathrm{Cu}_{2} \mathrm{O}$ NWAs & 97 & 95.8 & 26 \\
\hline 140 & $\mathrm{Cu}_{50} \mathrm{Ni}_{50}$ alloy & N/A & 93 & 27 \\
\hline 3000 & Porous $\mathrm{Cu}$ & 73 & 72 & 28 \\
\hline 140 & $\mathrm{Cu}$ nanosheets & N/A & 99.7 & 29 \\
\hline 280 & Co-NAs & N/A & 96 & 30 \\
\hline 200 & $\mathrm{Co} / \mathrm{CoO} \mathrm{NSAs}$ & 80.8 & 93.8 & 31 \\
\hline 100 & $\mathrm{Pd} / \mathrm{Cu}_{2} \mathrm{O}$ & 99.8 & 94.3 & 32 \\
\hline 1400 & $\mathrm{Ti}$ & N/A & 82 & 33 \\
\hline 50 & $\mathrm{TiO}_{2-x}$ & 95.2 & 85.0 & 34 \\
\hline 14000 & Ir NTs & N/A & 84.7 & 35 \\
\hline 14000 & $\mathrm{Ru}-\mathrm{ST}$ & N/A & 96 & 36 \\
\hline 140 & $\mathrm{OD}-\mathrm{Ag}$ & 99 & 89 & This work \\
\hline
\end{tabular}


Table S3. Content of gaseous products $\left(\mathrm{NO}_{2}, \mathrm{NO}\right.$, and $\left.\mathrm{N}_{2} \mathrm{O}\right)$ for the electro-reduction of $\mathrm{NO}_{3}{ }^{-}$or $\mathrm{NO}_{2}{ }^{-}$on OD-Ag. The electrolyte was $0.1 \mathrm{M} \mathrm{KCl}$ and the applied potential was $-1.50 \mathrm{~V}_{\mathrm{Ag} / \mathrm{AgCl}}$.

\begin{tabular}{ccccccc}
\hline Entry & Reactants & $\begin{array}{c}\text { Ar flow rate } \\
\left(\mathrm{mL} \mathrm{min}^{-1}\right)\end{array}$ & $\begin{array}{c}\text { Reaction } \\
\text { time (min) }\end{array}$ & Product detected & Content (ppm) & Charge (C) \\
\hline 1 & $0.05 \mathrm{M} \mathrm{NO}_{3}{ }^{-}$ & 12.5 & 4 & Total NO + $\mathrm{NO}_{2}$ & 3.0 & 25.4 \\
\hline 2 & $\begin{array}{r}0.025 \mathrm{M} \mathrm{NO}_{3}{ }^{-}+ \\
0.025 \mathrm{M} \mathrm{NO}_{2}{ }^{-}\end{array}$ & 20 & 35 & $\mathrm{~N}_{2} \mathrm{O}$ & 32.6 & 190.7 \\
\hline 3 & $\begin{array}{r}0.025 \mathrm{M} \mathrm{NO}_{3}{ }^{-}+ \\
0.025 \mathrm{M} \mathrm{NO}_{2}{ }^{-}\end{array}$ & 12.5 & 4 & Total NO $+\mathrm{NO}_{2}$ & 2.4 & 21.2 \\
\hline
\end{tabular}

Note: Estimation of FE of $\mathrm{N}_{2} \mathrm{O}$ based on Entry 2

$$
n_{\mathrm{N}_{2} \mathrm{O}}=20 \mathrm{~mL} \mathrm{~min}^{-1} \times 35 \mathrm{~min} \times 32.6 \times 10^{-6} \times 0.0416 \mathrm{~mol} \mathrm{~L}^{-1} / 1000=9.49 \times 10^{-7}(\mathrm{~mol})
$$

Assuming all $\mathrm{N}_{2} \mathrm{O}$ was reduced from $\mathrm{NO}_{3}^{-}\left(\mathrm{NO}_{2}^{-}\right)$, the upper (lower) limit of $\mathrm{FE}$ is

$$
\begin{aligned}
F E_{\mathrm{N}_{2} \mathrm{O}, \text { max }} & =\frac{9.49 \times 10^{-7} \mathrm{~mol} \times 4 \times 96485 \mathrm{C} \mathrm{mol}^{-1}}{190.7 \mathrm{C}} \times 100 \%=0.19 \% \\
F E_{\mathrm{N}_{2} \mathrm{O}, \text { min }} & =\frac{9.49 \times 10^{-7} \mathrm{~mol} \times 2 \times 96485 \mathrm{C} \mathrm{mol}^{-1}}{190.7 \mathrm{C}} \times 100 \%=0.096 \%
\end{aligned}
$$

Similarly, results in the above table show a negligible contribution of $\mathrm{NO}_{2}$ and $\mathrm{NO}(\leq 0.007 \%)$ to the total FE in the system. 
Table S4. Calculated zero-point energy corrections, entropies, and free energies of adsorbed species on $\mathrm{Ag}(111)$, and $\mathrm{Pd}(111)$ with respect to $\mathrm{NO}_{3}{ }^{-}(\mathrm{l}), \mathrm{H}_{2}(\mathrm{~g})$, and $\mathrm{H}_{2} \mathrm{O}(\mathrm{g})$ at $0.00 \mathrm{~V}_{\text {RHE}}$.

\begin{tabular}{l|cc|cc}
\hline & $Z P E[\mathrm{eV}]$ & $S[\mathrm{~J} / \mathrm{mol}-\mathrm{K}]$ & $\begin{array}{c}\Delta G_{\mathrm{Ag}(111)} \\
{[\mathrm{eV}]}\end{array}$ & $\begin{array}{c}\Delta G_{\mathrm{Pd}(111)} \\
{[\mathrm{eV}]}\end{array}$ \\
\hline $\mathrm{H}^{*}$ & 0.17 & 1.79 & 0.40 & -0.40 \\
\hline $\mathrm{O}^{*}$ & 0.07 & 12.26 & 2.20 & 1.28 \\
\hline $\mathrm{OH}^{*}$ & 0.33 & 29.41 & 0.94 & 1.03 \\
\hline $\mathrm{NO}_{3}{ }^{*}$ & 0.40 & 88.43 & -0.37 & -0.30 \\
\hline $\mathrm{HNO}_{3} *$ & 0.69 & 91.61 & -0.17 & -0.18 \\
\hline $\mathrm{NO}_{2}{ }^{*}$ & 0.27 & 67.54 & -2.35 & -2.49 \\
\hline $\mathrm{HNO}_{2} *$ & 0.56 & 91.76 & -2.13 & -2.21 \\
\hline $\mathrm{NO}^{*}$ & 0.14 & 60.01 & -3.26 & -5.18 \\
\hline $\mathrm{HNO}^{*}$ & 0.40 & 48.19 & -3.09 & -4.33 \\
\hline $\mathrm{NOH}^{*}$ & 0.49 & 33.00 & -0.59 & -4.21 \\
\hline $\mathrm{HNOH}^{*}$ & 0.82 & 48.52 & -1.15 & -4.27 \\
\hline $\mathrm{H}_{2} \mathrm{NO}^{*}$ & 0.82 & 46.55 & -1.56 & -4.27 \\
\hline $\mathrm{H}_{2} \mathrm{NOH}^{*}$ & 1.11 & 80.00 & -2.15 & -4.64 \\
\hline $\mathrm{N}^{*}$ & 0.09 & 8.15 & -3.33 & -5.98 \\
\hline $\mathrm{NH}^{*}$ & 0.39 & 11.90 & -4.88 & -6.43 \\
\hline $\mathrm{NH}_{2} *$ & 0.69 & 24.21 & -5.89 & -6.55 \\
\hline $\mathrm{NH}_{3}^{*}$ & 1.01 & 40.56 & -6.72 & -7.15 \\
\hline
\end{tabular}


Table S5. Calculated zero-point energy corrections, entropies, and free energies of $\operatorname{Ag}(211)$ with respect to $\mathrm{NO}_{3}{ }^{-}(\mathrm{l}), \mathrm{H}_{2}(\mathrm{~g})$, and $\mathrm{H}_{2} \mathrm{O}(\mathrm{g})$ at $0.00 \mathrm{~V}_{\mathrm{RHE}}$.

\begin{tabular}{l|ccc}
\hline & $Z P E[\mathrm{eV}]$ & $S[\mathrm{~J} / \mathrm{mol}-\mathrm{K}]$ & $\Delta G_{\mathrm{Ag}(211)}$ \\
\hline $\mathrm{H}^{*}$ & 0.15 & 2.82 & 0.46 \\
\hline $\mathrm{O}$ & 0.05 & 20.90 & 1.99 \\
\hline $\mathrm{OH}^{*}$ & 0.34 & 36.63 & 0.77 \\
\hline $\mathrm{NO}_{3}{ }^{*}$ & 0.39 & 102.03 & -0.74 \\
\hline $\mathrm{HNO}_{3}{ }^{*}$ & 0.68 & 74.42 & -0.27 \\
\hline $\mathrm{NO}_{2}{ }^{*}$ & 0.26 & 84.53 & -2.65 \\
\hline $\mathrm{HNO}_{2}{ }^{*}$ & 0.52 & 67.39 & -2.19 \\
\hline $\mathrm{NO}^{*}$ & 0.15 & 43.64 & -3.32 \\
\hline $\mathrm{HNO}^{*}$ & 0.42 & 47.50 & -3.26 \\
\hline $\mathrm{NOH}^{*}$ & 0.42 & 66.07 & -2.73 \\
\hline $\mathrm{HNOH}^{*}$ & 0.76 & 63.68 & -3.65 \\
\hline $\mathrm{H}_{2} \mathrm{NO}^{*}$ & 0.80 & 69.46 & -3.95 \\
\hline $\mathrm{H}_{2} \mathrm{NOH}^{*}$ & 1.10 & 66.63 & -4.23 \\
\hline $\mathrm{N}^{*}$ & 0.06 & 18.80 & -3.75 \\
\hline $\mathrm{NH}^{*}$ & 0.35 & 20.65 & -5.10 \\
\hline $\mathrm{NH}_{2}{ }^{*}$ & 0.68 & 33.12 & -6.35 \\
\hline $\mathrm{NH}_{3}{ }^{*}$ & 0.98 & 51.10 & -6.89 \\
\hline
\end{tabular}

Table S6. Calculated zero-point energy corrections, entropies, and free energies of $\mathrm{Cu}(111)$ with respect to $\mathrm{NO}_{3}{ }^{-}(\mathrm{l}), \mathrm{H}_{2}(\mathrm{~g})$, and $\mathrm{H}_{2} \mathrm{O}(\mathrm{g})$ at $0.00 \mathrm{~V}_{\mathrm{RHE}}$. Bolded numbers are $\mathrm{Cu}(111)$-based $Z P E$ and $S$; other values are taken from $\operatorname{Pd}(111)$.

\begin{tabular}{l|cc|c}
\hline & $Z P E[\mathrm{eV}]$ & $S[\mathrm{~J} / \mathrm{mol}-\mathrm{K}]$ & \multicolumn{1}{|c}{$\Delta G_{\mathrm{Cu}(111)}$} \\
\hline $\mathrm{H}^{*}$ & 0.17 & 1.79 & 0.01 \\
\hline $\mathrm{O}^{*}$ & $\mathbf{0 . 0 7}$ & $\mathbf{1 2 . 3 7}$ & $\mathbf{1 . 0 2}$ \\
\hline $\mathrm{OH}^{*}$ & $\mathbf{0 . 3 4}$ & $\mathbf{2 5 . 5 5}$ & $\mathbf{0 . 4 6}$ \\
\hline $\mathrm{NO}_{3}{ }^{*}$ & $\mathbf{0 . 4 0}$ & $\mathbf{7 4 . 9 3}$ & $-\mathbf{0 . 6 3}$ \\
\hline $\mathrm{HNO}_{3}{ }^{*}$ & $\mathbf{0 . 6 9}$ & $\mathbf{7 5 . 7 9}$ & $\mathbf{- 0 . 1 3}$ \\
\hline $\mathrm{NO}_{2}{ }^{*}$ & $\mathbf{0 . 2 7}$ & $\mathbf{7 0 . 0 4}$ & $-\mathbf{2 . 7 0}$ \\
\hline $\mathrm{HNO}_{2}{ }^{*}$ & $\mathbf{0 . 5 5}$ & $\mathbf{7 5 . 1 9}$ & $\mathbf{- 2 . 2 5}$ \\
\hline $\mathrm{NO}^{*}$ & $\mathbf{0 . 1 6}$ & $\mathbf{4 4 . 0 3}$ & $-\mathbf{3 . 9 8}$ \\
\hline $\mathrm{HNO}^{*}$ & 0.40 & 48.19 & -2.31 \\
\hline $\mathrm{NOH}^{*}$ & 0.49 & 33.00 & 0.19 \\
\hline $\mathrm{HNOH}^{*}$ & 0.82 & 48.52 & -0.36 \\
\hline $\mathrm{H}_{2} \mathrm{NO}^{*}$ & 0.82 & 46.55 & -0.78 \\
\hline $\mathrm{H}_{2} \mathrm{NOH}^{*}$ & 1.11 & 80.00 & -1.36 \\
\hline $\mathrm{N}^{*}$ & 0.09 & 8.15 & -2.55 \\
\hline $\mathrm{NH}^{*}$ & 0.39 & 11.90 & -4.10 \\
\hline $\mathrm{NH}_{2}{ }^{*}$ & 0.69 & 24.21 & -5.11 \\
\hline $\mathrm{NH}_{3}{ }^{*}$ & 1.01 & 40.56 & -5.94 \\
\hline
\end{tabular}


Table S7. Calculated activation energies (enthalpies) $[\mathrm{eV}]$ of direct and $\mathrm{H}$-assisted pathways on the surfaces considered in this study.

\begin{tabular}{c|c|c|c|c}
\hline & \multicolumn{2}{|c|}{$\mathrm{NO}_{3} *$ dissociation } & \multicolumn{2}{c}{$\mathrm{NO}_{2} *$ dissociation } \\
\hline & Direct & H-assisted & Direct & H-assisted \\
\hline $\mathrm{Ag}(211)$ & 1.14 & 0.12 & 1.68 & 0.18 \\
\hline $\mathrm{Cu}(111)$ & 0.51 & 0.06 & 0.55 & 0.15 \\
\hline $\mathrm{Ag}(111)$ & 1.12 & 0.13 & - & - \\
\hline $\mathrm{Pd}(111)$ & 0.57 & 0.14 & - & - \\
\hline
\end{tabular}

Table S8. The most stable adsorption configurations of $\mathrm{NO}_{3} *, \mathrm{HNO}_{3} *$, and $\mathrm{NO}_{2} *$ (top view). Atom colors for adsorbed species: $\mathrm{N}$ (light blue), $\mathrm{O}$ (red), $\mathrm{H}$ (white). The unit cell is shown with black lines.

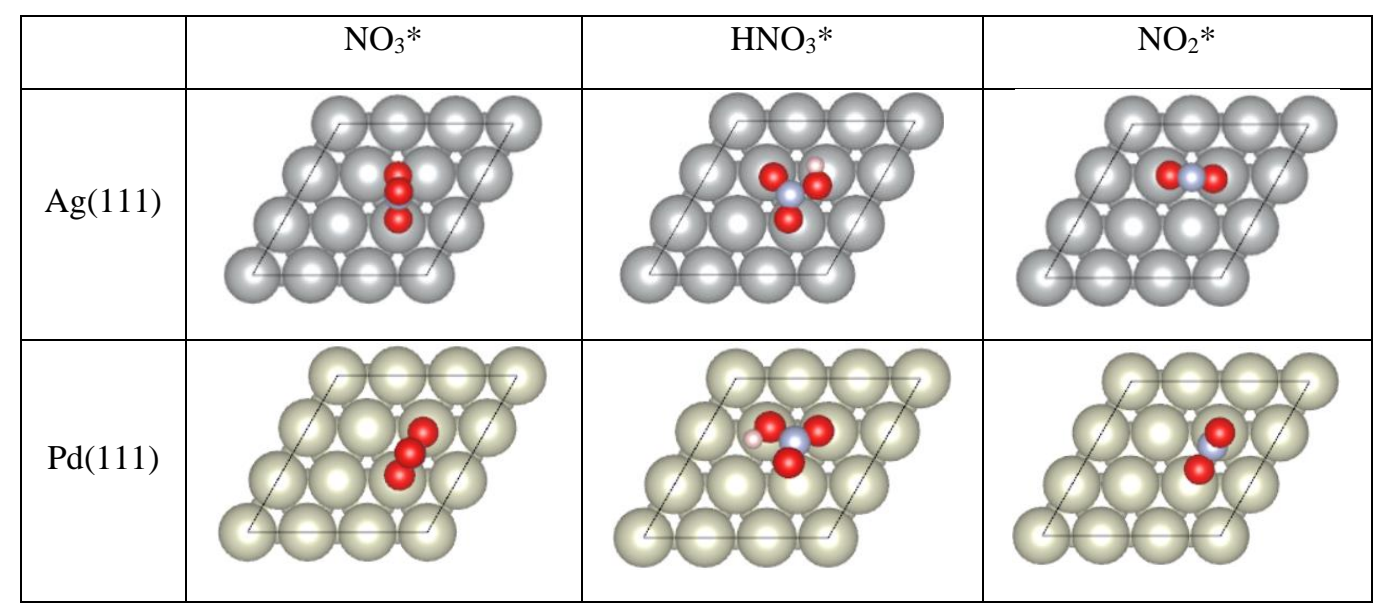


Table S9. Content of $\mathrm{NO}$ and $\mathrm{N}_{2} \mathrm{O}$ products for the catalytic reduction of $0.5 \mathrm{M} \mathrm{NO}_{2}^{-}$. Reaction conditions and calculation of flow rate are detailed in the Experimental Section.

\begin{tabular}{|c|c|c|c|}
\hline Reaction time (min) & Converted $\mathrm{NO}_{2}^{-}(\mathrm{mol})$ & $\begin{array}{l}\text { Detected NO } \\
(\mathrm{ppm})\end{array}$ & Detected $\mathrm{N}_{2} \mathrm{O}(\mathrm{ppm})$ \\
\hline 10 & \multirow{8}{*}{$\begin{array}{c}0.0075 \\
(\text { for } t=0-120 \mathrm{~min} \text { ) }\end{array}$} & 7.2 & \multirow{5}{*}{$\begin{array}{c}165.2 \\
(\text { for } t=0-60 \mathrm{~min} \text { ) }\end{array}$} \\
\hline 15 & & 3.6 & \\
\hline 20 & & 2.4 & \\
\hline 40 & & 1.0 & \\
\hline 60 & & $<1.0[\mathrm{a}]$ & \\
\hline 80 & & $<1.0$ & \multirow{3}{*}{$\begin{array}{c}236.3 \\
(\text { for } t=60-120 \mathrm{~min})\end{array}$} \\
\hline 100 & & $<1.0$ & \\
\hline 120 & & $<1.0$ & \\
\hline
\end{tabular}

[a] "<1.0 ppm" indicates the NO content was below the detection limit (1.0 ppm) of the nitrogen oxides detector tube.

Note: Estimation of selectivity to $\mathrm{NO}$ and $\mathrm{N}_{2} \mathrm{O}$ for $t=0-120 \mathrm{~min}$

$$
\begin{aligned}
& n_{\mathrm{N}_{2} \mathrm{O}}=14 \mathrm{~mL} \mathrm{~min}^{-1} \times 60 \mathrm{~min} \times(165.2+236.3) \times 10^{-6} \times 0.0415 \mathrm{~mol} \mathrm{~L}^{-1} / 1000 \\
& =1.40 \times 10^{-5}(\mathrm{~mol})
\end{aligned}
$$

The selectivity of $\mathrm{N}_{2} \mathrm{O}$ is

$$
S_{\mathrm{N}_{2} \mathrm{O}}=\frac{1.40 \times 10^{-5} \mathrm{~mol}}{0.0075 \mathrm{~mol}} \times 100 \%=0.19 \%
$$

Similarly, the estimated selectivity to NO is $0.0009 \%$ for $t=0-120 \mathrm{~min}$. 
Table S10. Summary of the experimental results of the combined denitrification process.

\begin{tabular}{|c|c|c|c|c|c|c|c|c|c|c|}
\hline \multirow[b]{2}{*}{$\begin{array}{l}\text { Reaction } \\
\text { medium }\end{array}$} & \multirow[b]{2}{*}{$\begin{array}{c}c_{0}\left(\mathrm{NO}_{3}{ }^{-}\right) \\
(\mathrm{ppm}-\mathrm{N})\end{array}$} & \multicolumn{5}{|c|}{ Step 1 (Electro-reduction on OD-Ag) } & \multicolumn{4}{|c|}{ Step 2 (Catalytic reduction on $\mathrm{Pd} / \mathrm{C}$ ) } \\
\hline & & $\begin{array}{c}\text { Potential } \\
\text { (V)[a] }\end{array}$ & $\begin{array}{c}\text { Charge } \\
\text { (C) }\end{array}$ & $\begin{array}{c}\mathrm{FE} \\
\left(\mathrm{NO}_{2}^{-}\right)\end{array}$ & $\begin{array}{l}\mathrm{FE} \\
\left(\mathrm{H}_{2}\right)\end{array}$ & $\begin{array}{c}X \\
\left(\mathrm{NO}_{3}^{-}\right)[\mathrm{b}]\end{array}$ & $\begin{array}{c}S \\
\left(\mathrm{NH}_{4}^{+}\right)[\mathrm{c}]\end{array}$ & $\begin{array}{l}c\left(\mathrm{NO}_{3}{ }^{-}\right) \\
(\mathrm{ppm}-\mathrm{N})\end{array}$ & $\begin{array}{l}c\left(\mathrm{NO}_{2}^{-}\right) \\
(\mathrm{ppm}-\mathrm{N})\end{array}$ & $\begin{array}{l}c\left(\mathrm{NH}_{4}{ }^{+}\right) \\
(\mathrm{ppm}-\mathrm{N})\end{array}$ \\
\hline \multirow{6}{*}{$\begin{array}{c}0.1 \mathrm{M} \mathrm{KCl} \\
(\mathrm{pH}=4)\end{array}$} & 140 & -1.10 & 31.5 & $82.0 \%$ & $4.9 \%$ & $98.8 \%$ & $1.8 \%$ & 1.7 & $-[\mathrm{d}]$ & 2.4 \\
\hline & 140 & -1.00 & 31.5 & $82.0 \%$ & $2.1 \%$ & $95.9 \%$ & $1.3 \%$ & 5.9 & - & 1.8 \\
\hline & 140 & -1.00 & 31.5 & $85.2 \%$ & $2.7 \%$ & $93.1 \%$ & $1.6 \%$ & 9.7 & - & 2.1 \\
\hline & 140 & -1.00 & 31.5 & $84.1 \%$ & $1.9 \%$ & $96.1 \%$ & $1.8 \%$ & 5.7 & - & 1.7 \\
\hline & 140 & -1.00 & 29.5 & $84.6 \%$ & $2.3 \%$ & $90.9 \%$ & $1.5 \%$ & 12.6 & - & 1.8 \\
\hline & 70 & -1.00 & 14.5 & $84.0 \%$ & $1.6 \%$ & $92.9 \%$ & $1.3 \%$ & 5.0 & - & 0.8 \\
\hline Simulated[e] & 140 & -1.00 & 33.5 & $80.6 \%$ & $3.8 \%$ & $97.4 \%$ & $1.6 \%$ & 1.7 & - & 2.4 \\
\hline Real[f] & 140 & -1.00 & 35.3 & $78.5 \%$ & $3.2 \%$ & $98.4 \%$ & $2.5 \%$ & 3.6 & - & 3.5 \\
\hline
\end{tabular}

[a] Potential (V) vs. Ag/AgCl.

[b] Conversion of $\mathrm{NO}_{3}{ }^{-}$.

[c] Selectivity to $\mathrm{NH}_{4}{ }^{+}$.

[d] "-" indicates the level of $\mathrm{NO}_{2}{ }^{-}$was below the detection limit of $1 \mu \mathrm{M}$ of the colorimetric method.

[e] Simulated waste stream from the ion-exchange columns. ${ }^{37}$

[f] Real agricultural wastewater from Des Moines Water Works, Iowa. 
Table S11. Summary of the reported electrocatalytic or catalytic systems for $\mathrm{NO}_{3}^{-}$removal. "N/A" indicates the parameter is not available in the publication.

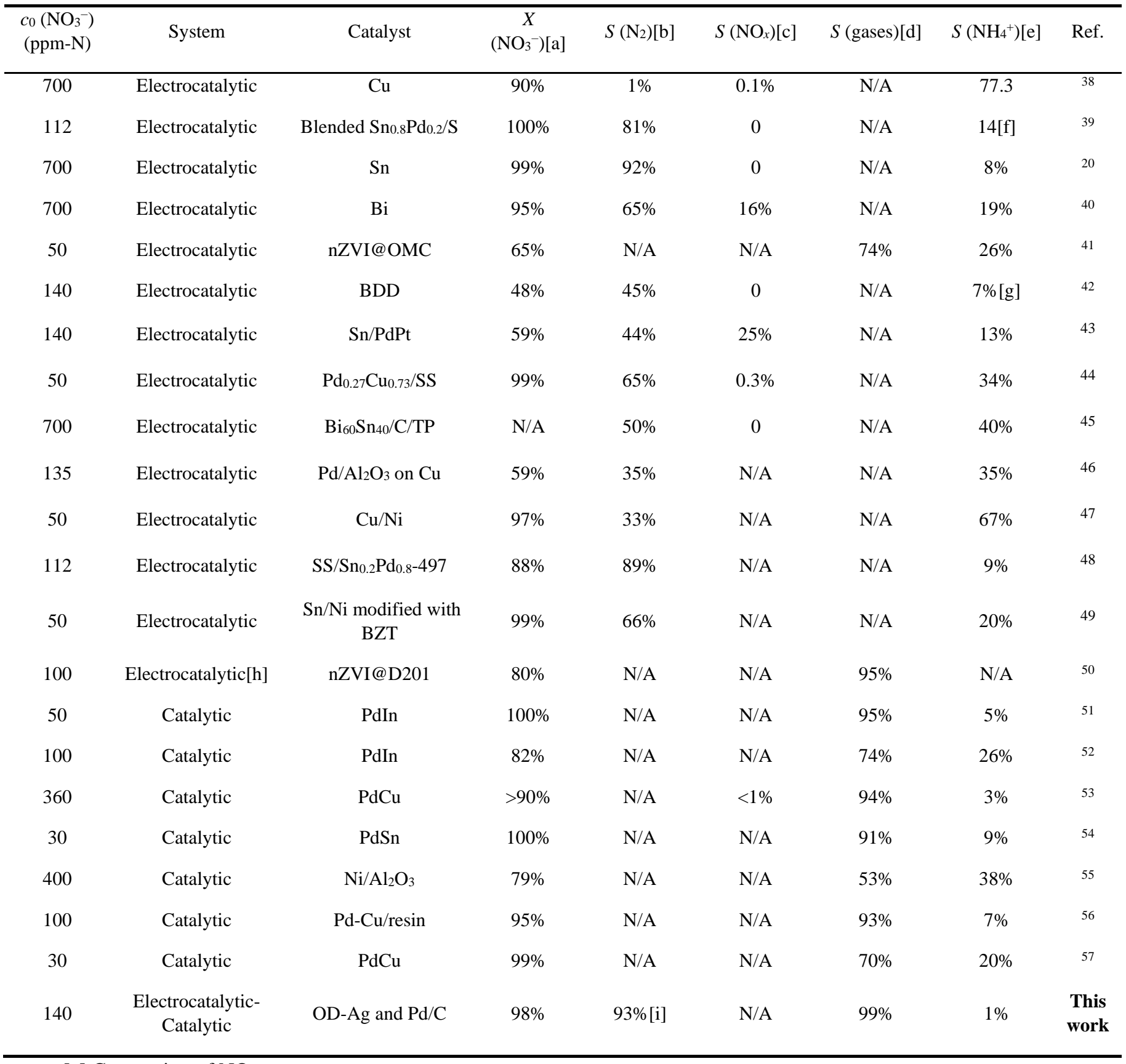

[a] Conversion of $\mathrm{NO}_{3}^{-}$.

[b] Selectivity to $\mathrm{N}_{2}$, as calculated by (Reacted $\mathrm{NO}_{3}{ }^{-}-$Produced $\mathrm{NH}_{4}{ }^{+}$- Produced $\mathrm{NO}_{2}{ }^{-}$) / (Reacted $\mathrm{NO}_{3}{ }^{-}$).

[c] Selectivity to $\mathrm{NO}_{x}$.

[d] Selectivity to gases product, as calculated by (Reacted $\mathrm{NO}_{3}{ }^{-}$- Produced $\mathrm{NH}_{4}{ }^{+}$- Produced $\mathrm{NO}_{2}{ }^{-}$) / $($Reacted $\mathrm{NO}_{3}^{-}$).

[e] Selectivity to $\mathrm{NH}_{4}{ }^{+}$. 
[f] Yield of $\mathrm{NH}_{4}{ }^{+}$, as calculated by Conversion of $\mathrm{NO}_{3}{ }^{-} \times$Selectivity of $\mathrm{NH}_{4}{ }^{+}$.

[g] $\mathrm{FE}$ of $\mathrm{NH}_{4}^{+}$.

[h] Electro-reduction of $\mathrm{NO}_{3}{ }^{-}$to $\mathrm{NH}_{4}{ }^{+}$coupled with electro-oxidation of $\mathrm{NH}_{4}{ }^{+}$to $\mathrm{N}_{2}$.

[i] Selectivity to $\mathrm{N}_{2}$, as quantified by on-line gas chromatography. 


\section{Supplementary Note 4. Technoeconomic Analysis (TEA) Estimation}

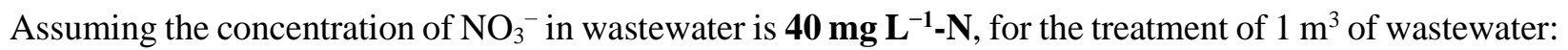

(1) Electrochemical $\mathrm{NO}_{3}{ }^{-}$-to- $\mathrm{NO}_{2}{ }^{-}$step:

$\mathrm{NO}_{3}^{-}+2 e^{-}+2 \mathrm{H}^{+} \rightarrow \mathrm{NO}_{2}^{-}+\mathrm{H}_{2} \mathrm{O}$

Mole of $\mathrm{NO}_{3}^{-}-\mathrm{N}$ for $1 \mathrm{~m}^{3}$ wastewater $=\left(40 \mathrm{mg} \mathrm{L}^{-1}-\mathrm{N} / \mathrm{m}^{3}\right) / 14 \mathrm{~g} \mathrm{~mol}^{-1}=2.86 \mathrm{~mole} / \mathrm{m}^{3}$

(a) Energy cost

Assuming $2.5 \mathrm{~V}$ cell voltage, $85 \%$ faradaic efficiency from $\mathrm{NO}_{3}{ }^{-}$to $\mathrm{NO}_{2}{ }^{-}$, and the renewable electricity price is $\$ 0.02 \mathrm{kWh}^{-1}$ (wind source in the next decade), ${ }^{58}$ then:

Electricity consumption $=2.86($ moles $) \times 96485\left(\mathrm{C} \mathrm{mole}^{-1}\right) \times 2 \times 2.5 \mathrm{~V} / 0.85=1.623 \mathrm{MJ}=0.45 \mathrm{kWh} / \mathrm{m}^{3}$ Electricity cost $=0.45\left(\mathrm{kWh} / \mathrm{m}^{3}\right) \times 0.02\left(\$ \mathrm{kWh}^{-1}\right)=\$ \mathbf{0 . 0 0 9} / \mathrm{m}^{3}$

(b) Catalyst cost

Assuming the used $\mathrm{Ag}$ is thin and with a lifetime of 1 year; the price of $\mathrm{Ag}$ is from BASF catalysts-Metal Prices; and the $\mathrm{NO}_{3}{ }^{-}$-to- $\mathrm{NO}_{2}^{-}$step rate is 5 gallon per minute (equivalent to approximately 2.6 million gallons per year), then:

Catalyst cost $=\$ \mathbf{0 . 0 0 2} / \mathrm{m}^{3}$

(2) Catalytic $\mathrm{NO}_{2}{ }^{-}$-to- $\mathrm{N}_{2}$ step:

$2 \mathrm{NO}_{2}^{-}+3 \mathrm{H}_{2}+2 \mathrm{CO}_{2} \rightarrow \mathrm{N}_{2}+2 \mathrm{HCO}_{3}^{-}+2 \mathrm{H}_{2} \mathrm{O}$

(a) Chemical cost

Assuming $\mathrm{H}_{2}$ utilization is $75 \%$, the mole of $\mathrm{H}_{2}$ needed for treatment of $1 \mathrm{~m}^{3}$ wastewater $=5.72 \mathrm{~mole} / \mathrm{m}^{3}$

DOE has set the cost target of $\mathrm{H}_{2}$ production by water electrolysis is $2 \$ / \mathrm{kg}-\mathrm{H}_{2} \cdot \frac{59}{} \mathrm{We}$ assume that $\mathrm{CO}_{2}$ is from industrial waste of ethanol fermentation $(\sim 100 \%$ purity) with no cost. $\underline{60}$

Chemical cost $=5.72\left(\mathrm{~mole} / \mathrm{m}^{3}\right) \times 2\left(\mathrm{~g} \mathrm{~mole}^{-1}\right) / 1000 \times 2\left(\$ \mathrm{~kg}^{-1}\right)=\$ 0.023 / \mathrm{m}^{3}$

(b) Catalyst cost

To have a fair comparison with the previous catalytic approach, we calculated and updated the "Pdnormalized constant" to $3.06 \mathrm{~L} \mathrm{~g} \mathrm{gd}^{-1} \mathrm{~min}^{-1}$ (based on $0.51 \mathrm{~min}^{-1}$ of measured pseudo first-order rate constant, and $50 \mathrm{mg}$ of $5 \mathrm{wt} . \% \mathrm{Pd} / \mathrm{C}$ in $15 \mathrm{~mL}$ of solution), instead of previous reported "surface Pd-normalized constant" with $k=27.96 \mathrm{~L} \mathrm{~g}_{\mathrm{Pd}}{ }^{-1} \mathrm{~min}^{-1}$ (Figure S26).

We assume $99 \%$ of removal rate, and factor $(f)$ will be $-1 / \ln (1-0.99)=1 /(4.605)=0.217$. Then, the needed amount of Pd to treat the capacity of 5 gallon-wastewater/min (i.e., $Q=18.92 \mathrm{~L} / \mathrm{min}$ ) will be $Q /(k \cdot f)=$ $(18.92 \mathrm{~L} / \mathrm{min}) /\left[\left(3.06 \mathrm{~L} \mathrm{~g}_{\mathrm{Pd}^{-1}} \mathrm{~min}^{-1}\right) \times(0.217)\right]=28.49 \mathrm{~g}-\mathrm{Pd}$.

We adopted the 5-year-average (2016-2020) cost of Pd metal (from www.Statista.com): $\$ 1,239 / \mathrm{oz}-\mathrm{Pd}=$ $\$ 39.8 / \mathrm{g}-\mathrm{Pd}$. Further, we consider there is $40 \%$ of production/manufacturing cost on top of material cost (consistent with BASF Pd catalyst), leading to the cost of Pd catalyst to be $\$ 55.7 / \mathrm{g}-\mathrm{Pd}$-catalyst.

We assume the catalyst can work for 5 years. Then, the cost of the Pd catalyst per $\mathrm{m}^{3}$ of wastewater will be $(\$ 55.7 / \text { g-Pd-catalyst })^{*}(28.49$ g-Pd-catalyst $) \times\left(1000 \mathrm{~L} / \mathrm{m}^{3}\right) /[(5$ years $) \times(365$ days $/$ year $) \times(24 \mathrm{hrs} /$ day $) \times(60$ $\mathrm{min} / \mathrm{hr}) \times(18.92 \mathrm{~L} / \mathrm{min})]=\$ 0.032 / \mathrm{m}^{3}$.

Total cost of our approach: $\mathbf{\$ 0 . 0 6 6 / \mathbf { m } ^ { 3 }}$ (i.e., $0.009+0.002+0.023+0.032$ ) 
Table S12. Summary of the reported cost for wastewater treatment of nitrate. ${ }^{[a]}$

\begin{tabular}{ccc}
\hline Methods & Capital Cost $\left(\$ \mathrm{~m}^{-3}\right)$ & Total Cost $\left(\$ \mathrm{~m}^{-3}\right)$ \\
\hline Ion exchange & $0.074-0.16$ & $0.17-0.38$ \\
Reverse osmosis & $0.26-0.34$ & $0.67-0.85$ \\
Electrodialysis & 0.37 & 0.55 \\
Biological denitrification & $0.16-0.21$ & $0.27-0.30$ \\
Catalytic denitrification & $0.156^{[\mathrm{b}]}$ & N/A \\
Our work & $\mathbf{0 . 0 6 6}$ & N/A \\
\hline
\end{tabular}

[a] From the ref. 61 in Tables 3.5, 3.7, 3.9, and 3.13 for ion exchange, reverse osmosis, electrodialysis, and biological denitrification methods, respectively, and changed the unit from $\$$ per 1,000 gallons to $\$$ per cubic meter.

[b] The reported data was calculated based the ref. 51 (using $\mathrm{H}_{2}$ to directly reduce $\mathrm{NO}_{3}{ }^{-}$to $\mathrm{N}_{2}$ ), with one of the best performances (highest selectivity of 95\%) in this filed.

Estimation of capital cost for the catalytic denitrification approach (ref. 51):

$2 \mathrm{NO}_{3}{ }^{-}+5 \mathrm{H}_{2}+2 \mathrm{CO}_{2} \rightarrow \mathrm{N}_{2}+2 \mathrm{HCO}_{3}{ }^{-}+4 \mathrm{H}_{2} \mathrm{O}$

(1) Chemical cost

Assuming the $\mathrm{H}_{2}$ utilization is the same as $75 \%$, the mole of $\mathrm{H}_{2}$ needed for treatment of $1 \mathrm{~m}^{3}$ wastewater $=$ $9.53 \mathrm{~mole} / \mathrm{m}^{3}$

Further assuming the cost of $\mathrm{H}_{2}$ production is the same as $2 \$ / \mathrm{kg}-\mathrm{H}_{2 ;}{ }^{59}$ and the cost of $\mathrm{CO}_{2}$ is free as well. ${ }^{60}$ Chemical cost $=9.53($ mole $) \times 2\left(\mathrm{~g} \mathrm{~mole}^{-1}\right) \times 2\left(\$ \mathrm{~kg}^{-1}\right)=\$ 0.038 / \mathrm{m}^{3}$

(2) Catalyst cost

The catalyst in that paper is In-Pd (40sc\%, with 5wt\%:95wt.\% of In:Pd), and the rate constant of pseudo first-order reaction is $0.087 \mathrm{~min}^{-1}(0.553 \mathrm{mg}-\mathrm{In}$ and $10.507 \mathrm{mg}-\mathrm{Pd}$ in $99.5 \mathrm{~mL}$ of solution). The "Pdnormalized constant" is $0.823 \mathrm{~L} \mathrm{~g}_{\mathrm{Pd}}{ }^{-1} \mathrm{~min}^{-1}$.

We ignored the cost of In because of its low composition and low cost, as compared with Pd, \$218/oz-In vs. $\$ 1,239 / \mathrm{oz}-\mathrm{Pd}$ (based on the 5-year-average cost from the same website).

Similarly, the calculated catalyst cost is $\$ 0.118 / \mathrm{m}^{3}$.

Total cost: $\mathbf{\$ 0 . 1 5 6 / \mathbf { m } ^ { 3 }}$ (i.e., $\$ 0.118+\$ 0.038$ ) 


\section{References}

(1) Martínez, J.; Ortiz, A.; Ortiz, I., State-of-the-art and perspectives of the catalytic and electrocatalytic reduction of aqueous nitrates. Appl. Catal. B 2017, 207, 42-59.

(2) Clark, C. A.; Reddy, C. P.; Xu, H.; Heck, K. N.; Luo, G.; Senftle, T. P.; Wong, M. S., Mechanistic Insights into $\mathrm{pH}-\mathrm{Controlled} \mathrm{Nitrite} \mathrm{Reduction} \mathrm{to} \mathrm{Ammonia} \mathrm{and} \mathrm{Hydrazine} \mathrm{over} \mathrm{Rhodium.} \mathrm{ACS} \mathrm{Catal.}$

2019, 10 (1), 494-509.

(3) Paidar, M.; Roušar, I.; Bouzek, K., Electrochemical removal of nitrate ions in waste solutions after regeneration of ion exchange columns. J. Appl. Electrochem. 1999, 29 (5), 611-617.

(4) Kresse, G.; Furthmüller, J., Efficient iterative schemes for ab initio total-energy calculations using a plane-wave basis set. Phys. Rev. B 1996, 54 (16), 11169-11186.

(5) Kresse, G.; Furthmüller, J., Efficiency of ab-initio total energy calculations for metals and semiconductors using a plane-wave basis set. Comput. Mater. Sci. 1996, 6 (1), 15-50.

(6) Blöchl, P. E., Projector augmented-wave method. Phys. Rev. B 1994, 50 (24), 17953-17979.

(7) Kresse, G.; Joubert, D., From ultrasoft pseudopotentials to the projector augmented-wave method. Phys. Rev. B 1999, 59 (3), 1758-1775.

(8) Perdew, J. P.; Wang, Y., Accurate and simple analytic representation of the electron-gas correlation energy. Phys. Rev. B 1992, 45 (23), 13244-13249.

(9) William M Haynes; David R Lide; Thomas J Bruno. CRC Handbook of Chemistry and Physics (Ed.:W.M.Haynes). CRC (2016).

(10) Monkhorst, H. J.; Pack, J. D., Special points for Brillouin-zone integrations. Phys. Rev. B 1976, 13 (12), 5188-5192.

(11) Calle-Vallejo, F.; Huang, M.; Henry, J. B.; Koper, M. T.; Bandarenka, A. S., Theoretical design and experimental implementation of $\mathrm{Ag} / \mathrm{Au}$ electrodes for the electrochemical reduction of nitrate. Phys. Chem. Chem. Phys. 2013, 15 (9), 3196-3202.

(12) Krukau, A. V.; Vydrov, O. A.; Izmaylov, A. F.; Scuseria, G. E., Influence of the exchange screening parameter on the performance of screened hybrid functionals. J. Chem. Phys. 2006, 125 (22), 224106.

(13) Nørskov, J. K.; Rossmeisl, J.; Logadottir, A.; Lindqvist, L.; Kitchin, J. R.; Bligaard, T.; Jónsson, H., Origin of the Overpotential for Oxygen Reduction at a Fuel-Cell Cathode. J. Phys. Chem. B 2004, 108 (46), 17886-17892.

(14) Chou, S.-S.; Chung, J.; Hwang, D., A high performance liquid chromatography method for determining nitrate and nitrite levels in vegetables. J. Food Drug Anal. 2003, 11 (3), 233-238.

(15) Chen, Y.; Liu, H.; Ha, N.; Licht, S.; Gu, S.; Li, W., Revealing nitrogen-containing species in commercial catalysts used for ammonia electrosynthesis. Nature Catal. 2020, 1-7.

(16) Kim, K.; Chen, Y.; Han, J.-I.; Yoon, H. C.; Li, W., Lithium-mediated ammonia synthesis from water and nitrogen: a membrane-free approach enabled by an immiscible aqueous/organic hybrid electrolyte system. Green Chem. 2019, 21 (14), 3839-3845.

(17) Burrell, D. S. F. a. R. C., Spectrophotometric Method for Determining Hydroxylamine Reductase Activity in Higher Plants. Anal. Chem. 1955, 27, 1664-1665.

(18) Kim, C.; Jeon, H. S.; Eom, T.; Jee, M. S.; Kim, H.; Friend, C. M.; Min, B. K.; Hwang, Y. J., Achieving Selective and Efficient Electrocatalytic Activity for $\mathrm{CO}_{2}$ Reduction Using Immobilized Silver Nanoparticles. J. Am. Chem. Soc. 2015, 137 (43), 13844-13850.

(19) Prelazzi, G.; Cerboni, M.; Leofanti, G., Comparison of $\mathrm{H}_{2}$ Adsorption, $\mathrm{O}_{2}$ Adsorption, $\mathrm{H}_{2}$ Titration, and $\mathrm{O}_{2}$ Titration on Supported Palladium Catalysts. J. Catal. 1999, 181 (1), 73-79.

(20) Katsounaros, I.; Ipsakis, D.; Polatides, C.; Kyriacou, G., Efficient electrochemical reduction of nitrate to nitrogen on tin cathode at very high cathodic potentials. Electrochim. Acta 2006, 52 (3), 13291338.

(21) Katsounaros, I.; Dortsiou, M.; Polatides, C.; Preston, S.; Kypraios, T.; Kyriacou, G., Reaction pathways in the electrochemical reduction of nitrate on tin. Electrochim. Acta 2012, 71, 270-276. 
(22) Akhade, S. A.; Bernstein, N. J.; Esopi, M. R.; Regula, M. J.; Janik, M. J., A simple method to approximate electrode potential-dependent activation energies using density functional theory. Catal. Today 2017, 288, 63-73.

(23) Luo, W.; Nie, X.; Janik, M. J.; Asthagiri, A., Facet dependence of $\mathrm{CO}_{2}$ reduction paths on $\mathrm{Cu}$ electrodes. ACS Catal. 2016, 6 (1), 219-229.

(24) Jitariu, L.; Hirst, D., Theoretical investigation of the potential energy surface for the reaction of $\mathrm{NO}_{3}$ with H. Phys. Chem. Chem. Phys. 1999, 1 (6), 983-987.

(25) Chen, G.-F.; Yuan, Y.; Jiang, H.; Ren, S.-Y.; Ding, L.-X.; Ma, L.; Wu, T.; Lu, J.; Wang, H., Electrochemical reduction of nitrate to ammonia via direct eight-electron transfer using a coppermolecular solid catalyst. Nat. Energy 2020, 5 (8), 605-613.

(26) Wang, Y., Zhou, W., Jia, R., Yu, Y. \& Zhang, B. Unveiling the activity origin of a copper-based electrocatalyst for selective nitrate reduction to ammonia. Angew. Chem. 2020, 132, 5388-5392.

(27) Wang, Y. et al. Enhanced nitrate-to-ammonia activity on copper-nickel alloys via tuning of intermediate adsorption. J. Am. Chem. Soc. 2020, 142, 5702-5708.

(28) Abdallah, R.; Geneste, F.; Labasque, T.; Djelal, H.; Fourcade, F.; Amrane, A.; Taha, S.; Floner, D., Selective and quantitative nitrate electroreduction to ammonium using a porous copper electrode in an electrochemical flow cell. J. Electroanal. Chem. 2014, 727, 148-153.

(29) Xianbiao Fu, X. Z., Xiaobing Hu, Kun He, Yanan Yu, Tao Li, Qing Tu, Xin Qian, Qin Yue, Michael R. Wasielewski, Yijin Kang. , Alternative route for electrochemical ammonia synthesis by reduction of nitrate on copper nanosheets. Appl. Mater. Today 2020, 19, 100620.

(30) Deng, X.; Yang, Y.; Wang, L.; Fu, X. Z.; Luo, J. L., Metallic Co Nanoarray Catalyzes Selective $\mathrm{NH}_{3}$ Production from Electrochemical Nitrate Reduction at Current Densities Exceeding $2 \mathrm{~A} \mathrm{~cm}^{-2}$. Adv. Sci. 2021, 2004523.

(31) Yu, Y.; Wang, C.; Yu, Y.; Wang, Y.; Zhang, B., Promoting selective electroreduction of nitrates to ammonia over electron-deficient Co modulated by rectifying Schottky contacts. Sci. China Chem. 2020, 63 (10), 1469-1476.

(32) Yin, H.; Peng, Y.; Xiong, S.; Chen, J.; Wang, C.; Wang, R.; Chen, Z.; Kuwahara, Y.; Luo, J.; Yamashita, H., Alloying effect-induced electron polarization drives nitrate reduction to ammonia. 2020. (33) McEnaney, J. M.; Blair, S. J.; Nielander, A. C.; Schwalbe, J. A.; Koshy, D. M.; Cargnello, M.; Jaramillo, T. F., Electrolyte Engineering for Efficient Electrochemical Nitrate Reduction to Ammonia on a Titanium Electrode. ACS Sustain. Chem. Eng. 2020, 8 (7), 2672-2681.

(34) Jia, R.; Wang, Y.; Wang, C.; Ling, Y.; Yu, Y.; Zhang, B., Boosting Selective Nitrate

Electroreduction to Ammonium by Constructing Oxygen Vacancies in $\mathrm{TiO}_{2}$. ACS Catal. 2020, 3533 3540 .

(35) Zhu, J. Y.; Xue, Q.; Xue, Y. Y.; Ding, Y.; Li, F. M.; Jin, P.; Chen, P.; Chen, Y., Iridium Nanotubes as Bifunctional Electrocatalysts for Oxygen Evolution and Nitrate Reduction Reactions. ACS Appl. Mater. Interfaces 2020, 12 (12), 14064-14070.

(36) Li, J.; Zhan, G.; Yang, J.; Quan, F.; Mao, C.; Liu, Y.; Wang, B.; Lei, F.; Li, L.; Chan, A. W. M.; Xu, L.; Shi, Y.; Du, Y.; Hao, W.; Wong, P. K.; Wang, J.; Dou, S. X.; Zhang, L.; Yu, J. C., Efficient Ammonia Electrosynthesis from Nitrate on Strained Ruthenium Nanoclusters. J. Am. Chem. Soc. 2020, 142 (15), 7036-7046.

(37) S. H\&old, K.-D. V., T. Tacke and M. Sellb, Development of catalysts for a selective nitrate and nitrite removal from drinking water. Catal. Today 1993, 17, 21-30.

(38) Polatides, C.; Kyriacou, G., Electrochemical reduction of nitrate ion on various cathodes ? reaction kinetics on bronze cathode. J. Appl. Electrochem. 2005, 35 (5), 421-427.

(39) Su, J. F.; Kuan, W.-F.; Liu, H.; Huang, C. P., Mode of electrochemical deposition on the structure and morphology of bimetallic electrodes and its effect on nitrate reduction toward nitrogen selectivity. Appl. Catal. B 2019, 257.

(40) Dortsiou, M.; Kyriacou, G., Electrochemical reduction of nitrate on bismuth cathodes. $J$. Electroanal. Chem. 2009, 630 (1-2), 69-74. 
(41) Teng, W.; Bai, N.; Liu, Y.; Liu, Y.; Fan, J.; Zhang, W. X., Selective Nitrate Reduction to Dinitrogen by Electrocatalysis on Nanoscale Iron Encapsulated in Mesoporous Carbon. Environ. Sci. Technol. 2018, 52 (1), 230-236.

(42) Kuang, P.; Natsui, K.; Feng, C.; Einaga, Y., Electrochemical reduction of nitrate on boron-doped diamond electrodes: Effects of surface termination and boron-doping level. Chemosphere 2020, 251.

(43) Hossain, M. M.; Kawaguchi, T.; Shimazu, K.; Nakata, K., Reduction of nitrate on tin-modified palladium-platinum electrodes. J. Electroanal. Chem. 2020, 864, 114041.

(44) Shih, Y.-J.; Wu, Z.-L.; Lin, C.-Y.; Huang, Y.-H.; Huang, C.-P., Manipulating the crystalline morphology and facet orientation of copper and copper-palladium nanocatalysts supported on stainless steel mesh with the aid of cationic surfactant to improve the electrochemical reduction of nitrate and $\mathrm{N}_{2}$ selectivity. Appl. Catal. B. 2020, 273, 119053.

(45) Sanjuán, I.; García-Cruz, L.; Solla-Gullón, J.; Expósito, E.; Montiel, V., Bi-Sn nanoparticles for electrochemical denitrification: activity and selectivity towards $\mathrm{N}_{2}$ formation. Electrochim. Acta 2020, $340,135914$.

(46) Beltrame, T. F.; Gomes, M. C.; Marder, L.; Marchesini, F. A.; Ulla, M. A.; Bernardes, A. M., Use of copper plate electrode and $\mathrm{Pd}$ catalyst to the nitrate reduction in an electrochemical dual-chamber cell.

J. Water Process. Eng. 2020, 35, 101189.

(47) Shih, Y.-J.; Wu, Z.-L.; Huang, Y.-H.; Huang, C.-P., Electrochemical nitrate reduction as affected by the crystal morphology and facet of copper nanoparticles supported on nickel foam electrodes $(\mathrm{Cu} / \mathrm{Ni})$.

Chem. Eng. J. 2020, 383, 123157.

(48) Su, J. F.; Kuan, W.-F.; Chen, C.-L.; Huang, C.-P., Enhancing electrochemical nitrate reduction toward dinitrogen selectivity on Sn-Pd bimetallic electrodes by surface structure design. Appl. Catal. AGen. 2020, 606, 117809.

(49) Shih, Y.-J.; Wu, Z.-L., Electroplating of surfactant-modified tin catalyst over a nickel foam electrode $(\mathrm{Sn} / \mathrm{Ni})$ for selective $\mathrm{N}_{2}$ yield from nitrate reduction as affected by $\mathrm{Sn}$ (200) and $\mathrm{Sn}$ (101) crystal facets. Appl. Catal. B. 2021, 285, 119784.

(50) Liu, Z.; Dong, S.; Zou, D.; Ding, J.; Yu, A.; Zhang, J.; Shan, C.; Gao, G.; Pan, B., Electrochemically mediated nitrate reduction on nanoconfined zerovalent iron: Properties and mechanism. Water Res. 2020, $173,115596$.

(51) Guo, S.; Heck, K.; Kasiraju, S.; Qian, H.; Zhao, Z.; Grabow, L. C.; Miller, J. T.; Wong, M. S., Insights into Nitrate Reduction over Indium-Decorated Palladium Nanoparticle Catalysts. ACS Catal. 2017, 8 (1), 503-515.

(52) Marchesini, F. A.; Picard, N.; Miró, E. E., Study of the interactions of Pd,In with SiO2 and Al2O3 mixed supports as catalysts for the hydrogenation of nitrates in water. Catal. Commun. 2012, 21, 9-13.

(53) Constantinou, C. L.; Costa, C. N.; Efstathiou, A. M., Catalytic removal of nitrates from waters. Catal. Today 2010, 151 (1-2), 190-194.

(54) Hamid, S.; Kumar, M. A.; Lee, W., Highly reactive and selective Sn-Pd bimetallic catalyst supported by nanocrystalline ZSM-5 for aqueous nitrate reduction. Appl. Catal. B 2016, 187, 37-46.

(55) Kobune, M.; Takizawa, D.; Nojima, J.; Otomo, R.; Kamiya, Y., Catalytic reduction of nitrate in water over alumina-supported nickel catalyst toward purification of polluted groundwater. Catal. Today 2020, 352, 204-211.

(56) Bradu, C.; Căpăţ, C.; Papa, F.; Frunza, L.; Olaru, E.-A.; Crini, G.; Morin-Crini, N.; Euvrard, E.; Balint, I.; Zgura, I., Pd-Cu catalysts supported on anion exchange resin for the simultaneous catalytic reduction of nitrate ions and reductive dehalogenation of organochlorinated pollutants from water. Appl. Catal. A-Gen. 2019, 570, 120-129.

(57) Santos, A.; Restivo, J.; Orge, C. A.; Pereira, M. F. R.; Soares, O., Nitrate Catalytic Reduction over Bimetallic Catalysts: Catalyst Optimization. $C$ 2020, 6 (4), 78.

(58) Smith, J. C.; Clark, C., The Future's Energy Mix: The Journey to Integration [Guest Editorial]. IEEE Power and Energy Magazine 2019, 17 (6), 19-23.

(59) Miller, E. L. In Hydrogen Production \& Delivery Program-Plenary Presentation, US DOE Annual Merit Review and Peer Evaluation Meeting, 2017. 
(60) Hunt, A. J.; Sin, E. H.; Marriott, R.; Clark, J. H., Generation, capture, and utilization of industrial carbon dioxide. ChemSusChem: Chemistry \& Sustainability Energy \& Materials 2010, 3 (3), 306-322. (61) Seidel, C.; Gorman, C.; Darby, J.; Jensen, V., An assessment of the state of nitrate treatment alternatives. Final Report of the American Water Works Association, Inorganic Contaminant Research \& Inorganic Water Quality Joint Project Committees 2011, 118-121. 


\section{Author Contributions}

W.L., L.T.R., and B.H.S. conceived and supervised the project. H.L. and Y.Q. performed the electrochemical measurements. H.L. and Y.Chen carried out the physical characterization. J.P. and K.S. carried out the DFT calculations. H.L., Y.Chen, and Y.Cheng performed the studies on the catalytic reduction of nitrite. S.G. helped with the design of the reactors for the electrocatalytic and catalytic activity measurements. All authors discussed the results and contributed to the manuscript writing. 